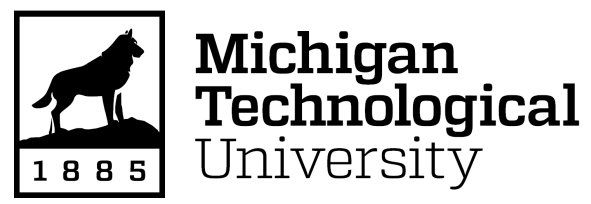

Michigan Technological University Digital Commons @ Michigan Tech

\title{
A SMALL-SCALE WATER BUDGET APPROACH AND WATER QUALITY ASSESSMENT: A CASE STUDY FOR CALDERAS LAKE, GUATEMALA
}

Edrick Ramos

Michigan Technological University, eramos@mtu.edu

Copyright 2016 Edrick Ramos

Recommended Citation

Ramos, Edrick, "A SMALL-SCALE WATER BUDGET APPROACH AND WATER QUALITY ASSESSMENT: A CASE STUDY FOR CALDERAS LAKE, GUATEMALA", Open Access Master's Report, Michigan Technological University, 2016.

https://doi.org/10.37099/mtu.dc.etdr/292

Follow this and additional works at: https://digitalcommons.mtu.edu/etdr

Part of the Environmental Monitoring Commons, Geology Commons, Hydrology Commons, and the Water Resource Management Commons 


\title{
A SMALL-SCALE WATER BUDGET APPROACH AND WATER QUALITY ASSESSMENT: A
} CASE STUDY FOR CALDERAS LAKE, GUATEMALA

\author{
By
}

Edrick Ramos

\begin{abstract}
A REPORT
Submitted in partial fulfillment of the requirements for the degree of MASTER OF SCIENCE

In Geology
\end{abstract}

MICHIGAN TECHNOLOGICAL UNIVERSITY

2016

(C) 2016 Edrick Ramos 
This report has been approved in partial fulfillment of the requirements for the Degree of MASTER OF SCIENCE in Geology.

Department of Geological and Mining Engineering and Sciences Report Advisor: John S. Gierke

Committee Member: Luke J. Bowman

Committee Member: Kari B. Henquinet

Department Chair: John S. Gierke 
For those who believe. 


\section{TABLE OF CONTENTS}

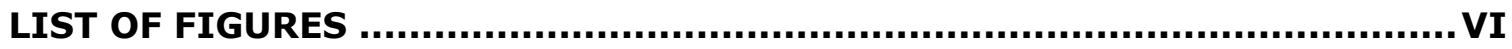

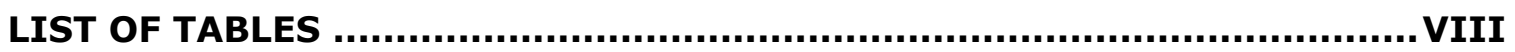

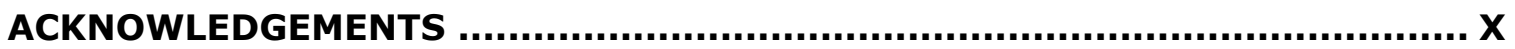

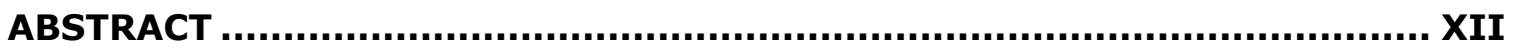

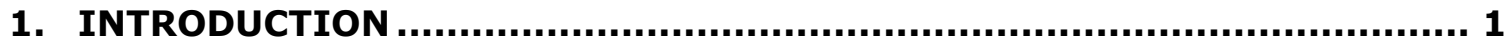

2. STUDY MOTIVATION AND OBJECTIVES............................................. 5

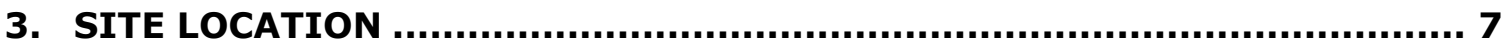

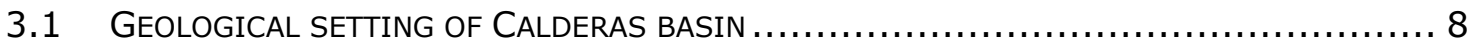

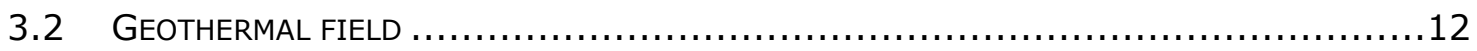

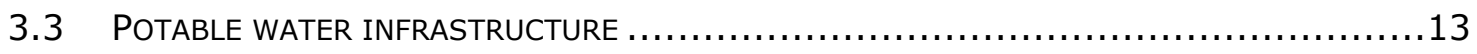

4. METHODS AND FIELDWORK ............................................................ 17

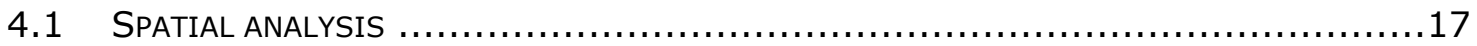

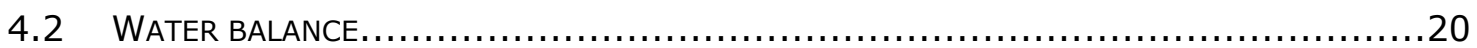

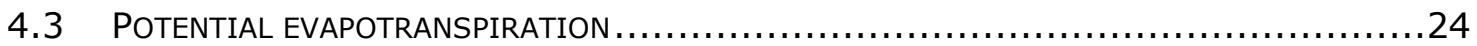

4.3.1 Thornthwaite-Mather method ..........................................24

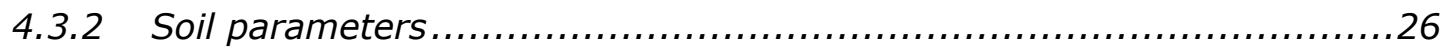

4.3.3 Hamon equation .......................................................... 32

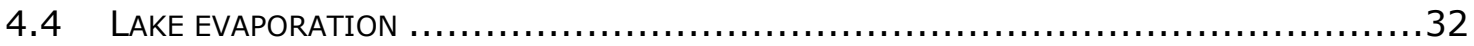

4.4.1 Blaney-Criddle equation................................................ 33

4.4.2 Papadakis equation ...................................................... 33

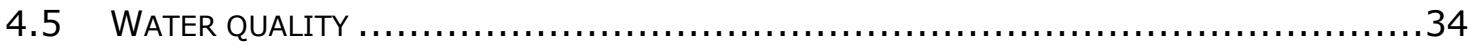

4.5.1 Partial chemistry .......................................................... 34

4.5.2 Microbiological indicators ............................................ 37

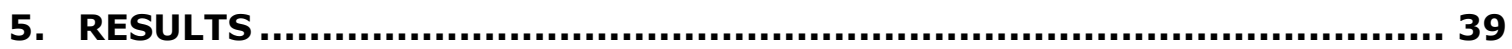

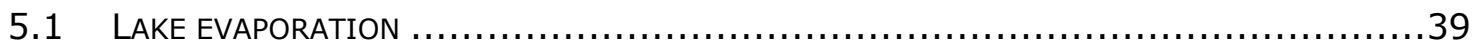

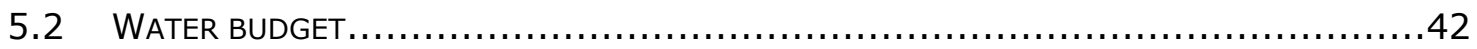

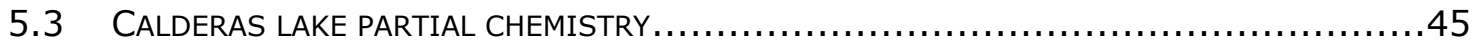

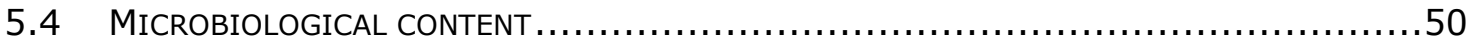




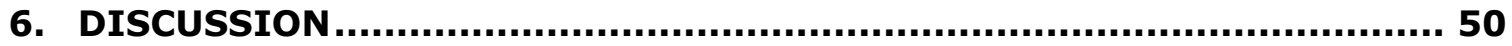

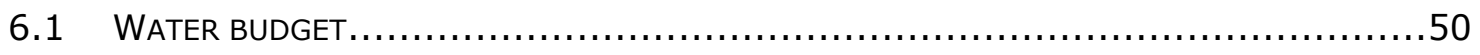

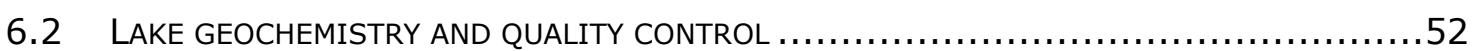

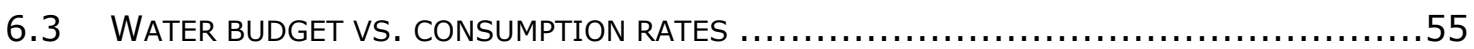

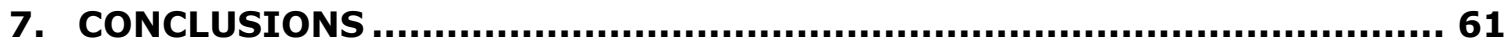

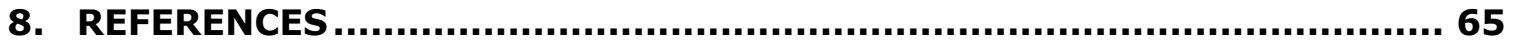

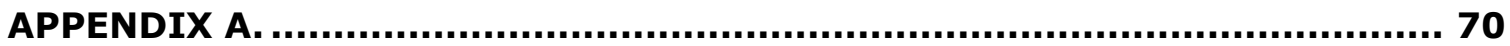

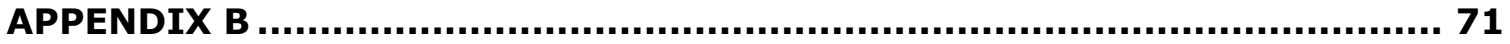




\section{List of Figures}

Figure 1. Conceptual hydrologic cycle of a caldera lake watershed................... 2

Figure 2. Map of Calderas watershed............................................. 7

Figure 3. Geologic map of Calderas quadrangle. Location of Calderas Lake and main geological and structural features.................................................

Figure 4. Geothermal wastewater disposal pond, located approximately $250 \mathrm{~m} \mathrm{~W}$ of Calderas Lake (photo: author).

Figure 5. Calderas community intake. Pumping rate reaches an approximate of $200 \mathrm{~m}^{3}$ per day (photo: author).

Figure 6. Common household water storage container and distribution pipe (photo: author)....

Figure 7. Calderas community water storage tank for gravity-distribution system (photo: author).

Figure 8. Maria Linda river basin, sub-basins, tributaries and surface water bodies. Note the lack of tributaries at Calderas watershed. .................................. 18

Figure 9. Hypsometric curve of Calderas watershed.

Figure 10. Adjusted mean annual precipitation $(\mathrm{mm})$ dataset for Calderas catchment from 2009-2015 period. Vertical bars represent the standard deviation of the means. (source: www.aWhere.com)

Figure 11. Adjusted mean annual precipitation $(\mathrm{mm})$ for Calderas catchment from 2009-2015 period. Vertical bars represent the standard deviation of the means. (source: www.aWhere.com) .... .24

Figure 12. Thornthwaite-Mather water balance components. .25

Figure 13. Observed soil horizons at Calderas basin. Andisol b horizon at the bottom, Vitrand A horizon (notice volcanic glass and lapillis) and Andisol O horizon at the very top (photo: author).

Figure 14. Normalize difference vegetation index for Calderas watershed, pie chart shows area of each characteristic enclosed in the catchment area. 29

Figure 15. View of Calderas Lake and south section of the basin. (photo: author)...30 Figure 16. View of Calderas Lake from Cerro Chino. Note the natural forest cover of protected area. (photo: author). 31

Figure 17. Sampling point locations at Calderas Lake. (Source: google earth) ........35

Figure 18. Test strip water sampling for partial chemistry. (photo: author)..... .35 
Figure 19. $3 \mathrm{~m}$ Petrifilm ${ }^{\mathrm{TM}}$ counting plates, no bacterial contamination (left) and total coliform and E. coli contamination (right). (photo: author) .......................... 38 Figure 20. Comparison of computed et using different methods.

Figure 21. Uptrend linear correlation (red line) between $E_{L}$ calculations from Hamon and estimations from Blaney-Criddle.

Figure 22. Thornthwaite type water balance for Calderas watershed for 2009-2015 period.

Figure 23. a) Hardness and Alkalinity diagrams for field measurements (green), MDEQ sample subset (black) and historical data from AMSA, 2007(red); b) TDS and Conductivity diagrams for field measurements (green), MDEQ sample subset (black) and AMSA's 2007 (red) and 2008 (blue) historical data; c) pH diagram comparison between AMSA historical data for 2007 (red) and 2008 (blue) . .....................46

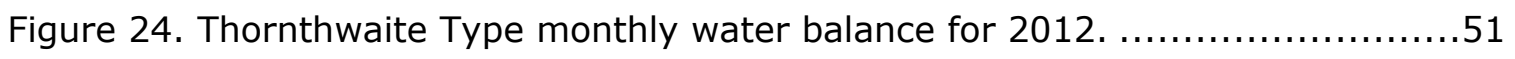

Figure 25. Linear regression plot between measured lake depth and estimated

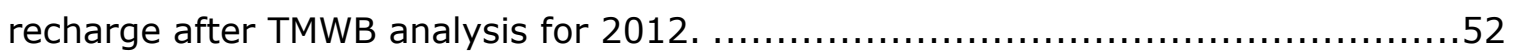

Figure 26. Input-output relationship pie chart for Calderas Lake. ...................55

Figure 27. Satellite view of the area showing Amatitlán cauldron (dashed yellow) after Wunderman \& Rose (1982), fault zones (black) mapped by Eggers (1975) and Calderas micro-basin (dashed green) within the system. Cross-section profiles from W to $\mathrm{E}$ and $\mathrm{S}$ to $\mathrm{N}$, profile intersection at Calderas Lake (modified from Google Earth).

Figure 28. a) A-A' cross-section from San Vicente (W) to Amatitlán cauldron wall (E). Interpretation of groundwater behavior based (Rios-Sanchez et al., 2012) groundwater flow regimes, Calderas water budget and geochemical analysis. b) B-B' cross-section and hydrological interpretation from Pacaya volcano (S) to Amatitlán

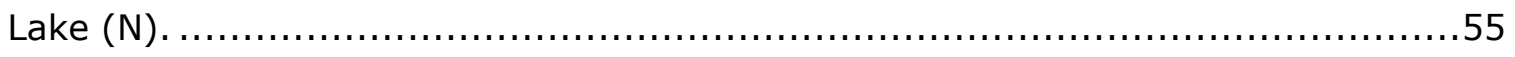

Figure 29. a) Septic contamination from cattle around Calderas Lake shoreline. b) House drainage into the lake (photo: author) .................................55 


\section{List of Tables}

Table 1. Morphometric parameters of Calderas watershed............................ 18

Table 2. NDVI values for land cover approximation for GIS analysis of Calderas

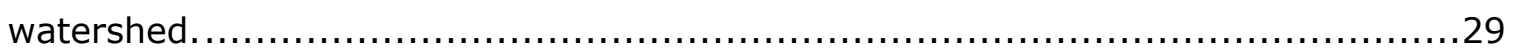

Table 3. Range values for root zone depth and field soil capacity calculates used for

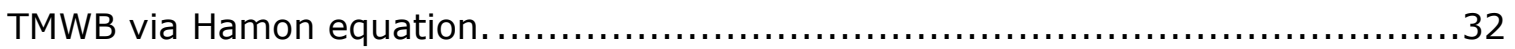

Table 4. Summary of water quality analytical methods. .............................. 36

Table 5. Comparison of mean monthly computed $E_{L}$ values for 2009-2015 period. ..41

Table 6. Comparison of average annual $E_{L}$ computed between methods for 2009-2015

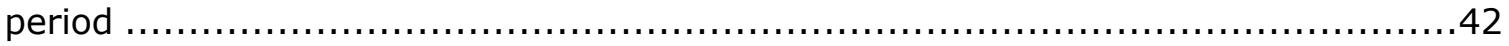

Table 7. Water budget components for Calderas basin for $2009-2015$ period. ........44

Table 8. Chemical composition in $(\mathrm{mg} / \mathrm{l})$ of sampled water tests in Calderas Lake from

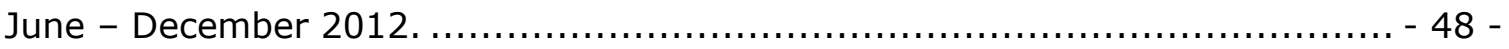

Table 9. Major and minor concentrations (in $\mathrm{mg} / \mathrm{l}$ ) of Calderas Lake water chemistry sampled prior to 2012. $-49-$

Table 10. Partial chemistry concentrations (in $\mathrm{mg} / \mathrm{l}$ ) of post-field water sampled tests.

Table 11. Summary of total coliform and E.coli most probable number as colony forming units (CFUs). .50

Table 12. Mean $(\boldsymbol{X})$ and standard deviation $(\delta)$ of water quality parameters for field sampling, MTU laboratory processing, and DEQ subset in comparison to previous data from AMSA and who permissible limits. .54 


\section{Acknowledgements}

I would like to thank my advisor Dr. John Gierke, for his support and advice through my Peace Corps service and after. His patience, encouragement and continuous persuasion during the completion of this report conveyed in me a spirit of adventure, research and unraveled in myself excitement for teaching. PCMI director Dr. Kari Henquinet for her wise advice and support during my last semester at Tech. Dr. Luke J. Bowman for true support along the journey, technical and moral support during the last stretch of this report. Graduate School's Dr. Nancy Byers Sprague for all the support and logistics with the extensions. M.Sc. Mariah Maggio who enlightened and provided ideas and moral support to conduct this research. PCMI Lindsay Davis for sampling processing. The peace corps MI project D96190 for funding part of this study. The Department of Geological \& Mining Engineering \& Science (GMES) Staff: Amie Ledgerwood, Kelly McLean and Brittany Buschell for their endless assistance either on-campus as abroad. Their warmth dedication is a grace to our department.

Thanks to GMES staff, PCMI colleagues and INVOGE graduate students that assisted me and provided strength, support and lots of memories during my time in campus. Dr. Bill Rose, none of this beautiful community wouldn't exist without you, Mariah and Jarod Maggio, Hans Lechner and Emily Gochis, Kyle Brill and Michelle Cisz, Rüdiger Escobar and Stephanie Tubman, Miriam Rios, Elisa Piispa, Teresa Muñoz and her family, Tyler Barton, Lauren Schaefer, Erika Vye, Eduardo Cabret, Federica Lanza, Kyung In-Huh, Evgeniy Kulakov, Geoffrey Lerner, Aurelia Ligler, Josep Cabré, Marine Foucher, Ashley Miller, Priscilla Addison, Ezequiel Medici, for their help on putting some life pieces together, research guidance, moral support, but most of all; your friendship. Much love to you all.

Much of this report wouldn't have been possible without my friends and colleagues at San José Calderas community. The Estupe-Peralta family, their constant support helped me to overcome the physical and emotional challenges of Peace Corps. The Peace Corps Guatemala administration, Flavio Linares, Craig Badger and Patty de Rossell for their support and logistics on completing the research on-site. The people from the Pacaya Volcano park administration, especially Aroldo Mijangos, Humberto Morales and Luis Revolorio, for facilitating many trips around the area and help to understand much of the water situation. Luis and Paola Gonzalez, your leadership should be a source of inspiration for Calderas community youth. Gustavo Chigna from INSIVUMEH for providing meteorological data used in this research. AMSA's Oscar Anibal Rivera and Stephany Fuentes for sharing water quality information on Calderas Lake. 
Last but not least, I would like to thank my loved ones for their support through the entire process on developing this project. My mother, her harmonious words and faith kept me focused. Ali, who has supported me from the beginning and beyond all circumstances, this work, would not have been possible without her devoted love. 


\section{Abstract}

Increases in water demand and urban development in Calderas community over the past decade have led to questions about the hydrology, water quality, quantity and sustainable management of Calderas Lake micro-basin. However, studies on baseline hydrology are limited for rural communities located inside volcanic origin watersheds of Guatemala. The scope of this study was to characterize the hydrology and establish a method to: 1) quantify a water budget, and 2) qualify the water quality of a lacustrine system that supply water for about 17,000 inhabitants on the state limits or rural Guatemala City. Mean annual rainfall and temperature at the watershed from 2009-2015 was 1,688 mm and $20^{\circ} \mathrm{C}$, respectively. A Thornthwaite monthlybased water balance model was tested on Calderas micro-basin using three different methods [Hamon, Blaney-Criddle, and Papadakis] for estimating lake evaporation within the water budget. These methods revealed that a small fraction (less than $5 \%$ ) of evaporates from Caldera's lake having small impacts as outflows of the system. A surplus up to $25 \%$ is estimated as net precipitation after establishing the relation between water inputs and outputs of Calderas micro-basin.

Partial chemistry sampling $(n=39)$ at Calderas Lake community intakes revealed no significant changes over a 6-month period. Chemical concentrations on Calderas Lake fall within national and international permissible levels for human consumption. Mean concentration for partial chemistry on alkalinity, $\mathrm{pH}$, phosphates, hardness, chloride, Na\%, nitrate, ammonia, TDS, and conductivity were $189 \mathrm{mg} / \mathrm{l}, 8$, $6 \mathrm{mg} / \mathrm{l}, 248 \mathrm{mg} / \mathrm{l}, 14 \mathrm{mg} / \mathrm{l}, 0.003 \%, 0.1 \mathrm{mg} / \mathrm{l}, 0.1 \mathrm{mg} / \mathrm{l}, 217 \mathrm{mg} / \mathrm{l}$, and $334 \mu \mathrm{S}$, respectively. Contrary to high values of CFU's measured on 2 water samples from each intake, 1 sample from Calderas elementary school water storage and 1 from Amatitlán lake as biological reference for E. coli and total coliforms. Mean CFU's for E. coli and total coliform were 4 and 9, respectively. According to local and international regulations, microbiological indicators exceed quality standards for human consumption. These results may have implications on watershed management practices and provide necessary baseline hydrologic, water quantity and water quality for Calderas micro-basin.

Key words: volcanic lake water budget; evapotranspiration; Laguna Calderas; Calderas watershed; TMWB; partial chemistry; Guatemala hydrology 


\section{Introduction}

Every watershed serves as the geological area in which the hydrological chemical cycling are coupled with ecological and biological communities linked by its common watercourse. Watersheds are also known as catchments or basins, briefly defined as the area of land where all the water above and under the surface drains to the same place (streams, wetlands, lakes, oceans or aquifers) (Dingman, 2002). All living organisms settled within the limits of a watershed are inextricably linked by their water system through the water cycle. The hydrologic cycle is naturally continuous and its important phases are: (i) evaporation and evapotranspiration, (ii) precipitation and (iii) runoff. Hence, characterizing the distribution and quality of water at reservoirs require in-depth data gathering and analysis of the hydro-meteorological and geological variables that govern the basin.

In recently active volcanic areas in tropical regions, caldera lakes ${ }^{1}$ are important water systems that supply water, habitat for fish and other aquatic resources, and a venue for outdoor recreation and tourism. Because of their remote locations and complexity in mountainous watershed terrains, the hydrology of caldera lakes is relatively poorly understood. The conceptual hydrological cycle for a hypothetical caldera watershed is depicted in Figure 1. Evaporation from a caldera lake reaches the atmosphere. As moist air reaches higher elevations, the water vapor gets cooled and is then condensed to form clouds. The moisture from clouds is then transported where condensation aids in surface return forming precipitation, which falls mainly in the form of drizzle, rain, and are driven by latitude, sunlight, pressure, temperature, wind direction and velocity, humidity and geography (Dingman, 2002). Precipitation can be stored temporarily as groundwater and its composition and physical properties may change as it flows through the surficial deposits and aquifers. Therefore, detailed studies of subsurface geology of the area are needed to identify its conditions and changes over time. Thus, it is not always easy to obtain information below the surface due to its high costs, maintenance and available resources.

${ }^{1} \mathrm{~A}$ caldera is a depression formed from the collapse of a magma chamber after a volcanic eruption or by subsurface magma migration. 


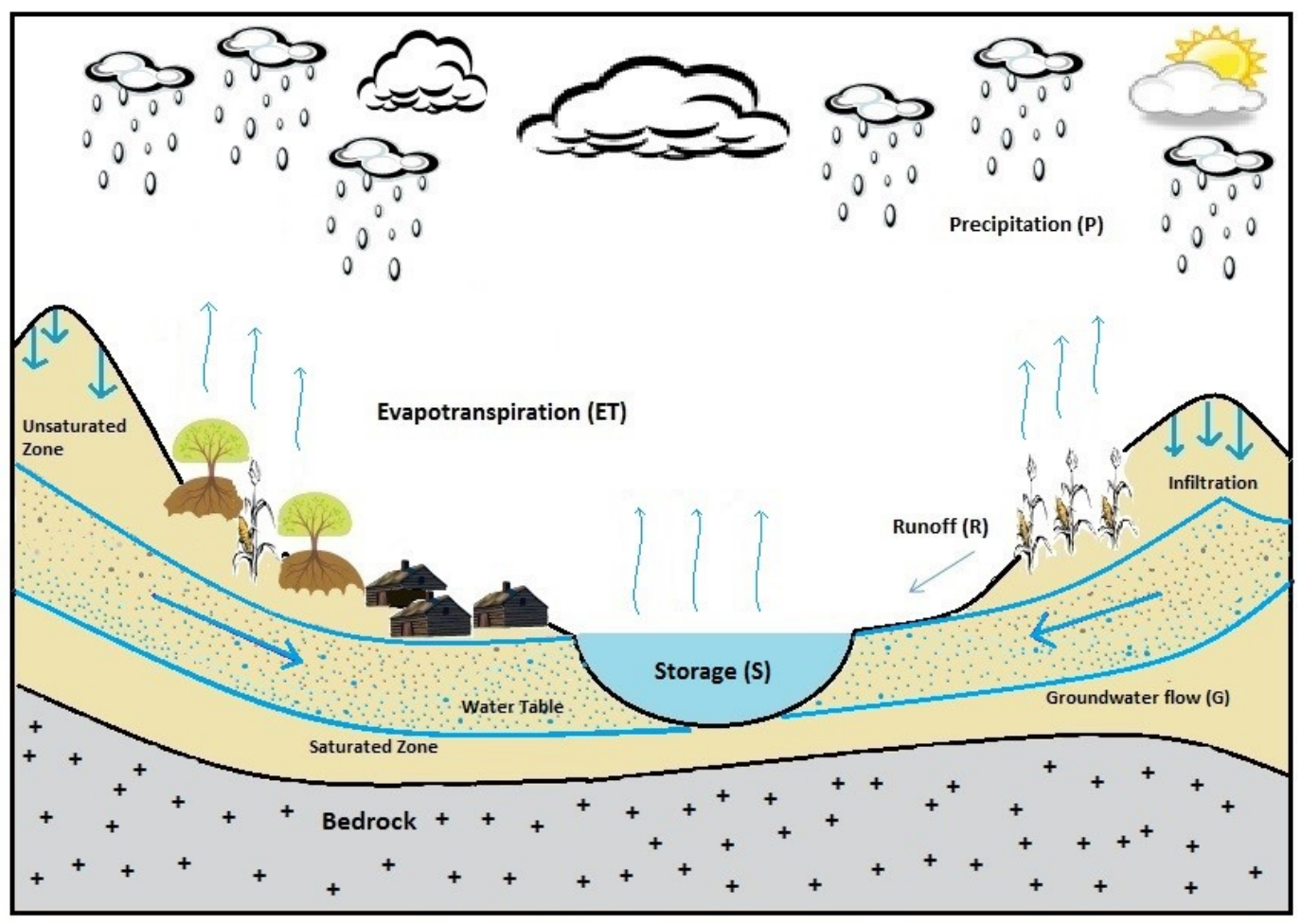

Figure 1. Conceptual hydrologic cycle of a caldera lake watershed.

Estimation on the flux of water through a system is identified to be a water budget. Water origins and interactions need to be measured in order to establish the water budget components that govern a watershed. These can vary depending on the region, geography and climate conditions of an area. Such components for tropical settings in a caldera watershed are precipitation, evapotranspiration, evaporation, surface water, ground-water flow, changes in storage (surface water-groundwater) and human interactions such as inputs and withdrawals. Establishing a water budget is crucial for determining water availability for human consumption, other uses, and identifying the stressing factors that exists or that could be developed in an area over time.

Initially, water precipitates into land and runs through the surface as elevation decreases. The journey continues after percolating the soil and draining vertically downwards into the substrate. Consequently, a small water percentage is intercepted, stored, used by plant roots, and then returning to the atmosphere - varying from plant type and root depth- through evapotranspiration (a combination between soil evaporation and plant transpiration). The water cycle is continuous, water keeps 
flowing through the porous soil and fractured rocks recharging the aquifer that restores surface water levels at a caldera lake. Many equations have been developed to quantify water loss from lakes through evaporation (Rosenberry et al., 2007). Yet, most of the equations are developed for use in specific studies and are intended to use in climates similar to where they were developed. Evaporation is considered a major component of a lake water balance, its variability makes it difficult to estimate it and has rarely been measured directly in Guatemala. Recent studies had used combinations of in situ measurements with remote sensing for determining lake variations (Medina et al., 2010) providing valuable information for monitoring a shallow sub-tropical water body. However, the scarcity of field data or ground surveys in such areas makes it difficult to create a historical dataset for estimating water balance components.

Lake Caldera water levels decrease as the rainy season develops and ends through a year. Contrary, water levels increase over months of lower precipitation input (Jan-Apr) based on in-site observations from villagers. Infiltration surplus after evaporation and evapotranspiration, aquifer recharge, and groundwater flow are responsible for lake water levels neglecting anthropogenic withdrawals. Theoretically, hydrological processes associated with lakes, such as seasonally high lake levels and evaporation-evapotranspiration of groundwater from around the perimeter of the lake are a major cause of the seasonally dynamic groundwater flow fields associated with lakes (Winter, 1999).

Lastly, community withdrawals play an important component on a lake water balance. The lake is mainly used as a water supply for human consumption and minor agricultural practices. Such component is considered as a major influential output at caldera's lake since no monitoring is been undertaking by any local or international authority. In order to estimate a water budget, quantities of withdrawals are needed to understand the hydrological stress given to the system.

Public concern about water quality in rural Guatemala is becoming an increasing trend among its citizens. Point source (PS) and nonpoint (diffuse) sources (NPS) of pollution within watersheds and water bodies have been extensively studied globally and recognized to be the leading cause of water deterioration (GWP, 2011; Illman, 2006; WHO, 1996). Primary point source loading originated in the watershed are identified to come from discharge pipes from near-shore housing, detergent from laundry making inside the lake, and animal fecal discharge around the lake shoreline. 
A common practice is to feed cattle and horses with lake's algae as villagers rake Hydrilla verticallata to the shoreline and bring their animals to the shoreline for such matters. Nonpoint sources around Calderas watershed are diffuse, distributed over land and discharged to caldera's lake by surface runoff, agricultural activities and other diffuse pollution such as sediment loading or solid waste transport. The scope of this project is to identify the hydrological components of Calderas watershed through an empirical water budget and a basic water quality assessment for establishing baseline hydrological information for a caldera watershed in Guatemala. To our knowledge, this is the first time Calderas watershed water balance is estimated. 


\section{Study motivation and objectives}

The motivations for developing a baseline hydrological description in a developing country setting were inspired by my service as a Peace Corps environmental educator volunteer in the village of San José Calderas, Guatemala. My duties were to live and work closely with local groups, schools, municipal authorities and to a lesser extent with the geothermal plant for identifying and addressing environmental issues from villagers and authorities in relation to Calderas Lake as a water resource. The ultimate goal was to promote cohesion between these groups for protecting the water resources.

Community leaders emphasized their need for clean and safe water for consumption. Thus, their specific needs were focused on infrastructure improvements from municipal authorities and not on environmental awareness from the villagers. While, municipal authorities hesitated to offer improvements due to lack of available funding, the geothermal plant funded small environmental projects within local schools to promote environmental awareness towards their water resources. However, the geothermal plant was seen as the one who brought pollution to their water supply.

Initial surveys around the community determined that the lake levels were not monitored on a regular basis and that no strategy for monitoring their water supply was undertaken at a local level. Also, some villagers still use the lake for domestic purposes -like laundry, bathing and as an animal feedlot- and neither local nor municipal authorities penalize such actions from the villagers. Although, access to water is available to households through external storage and pipe network, villagers seemed uncomfortable with the overall quality of the water.

Some proposed projects in the area included: construction of a new storage tank for enhancing water distribution to households and construction of a community washing station. However, proper estimation of hydrologic parameters must be identified in order to overcome potential stress to their water supply and the contributing watershed if proposed projects become a reality. Prior to giving recommendations to pertinent authorities, a quantitative assessment of their resource conditions must be made. 


\section{Objective 1: evaluate surface water quality for determining consumption suitability.}

Characterizing geochemical and microbial parameters in water supplies is necessary to properly assess and manage the water supply for consumption. The information can be used for establishing a record through time. Further identification of variances in relation to contamination sources that pollute these supplies can be made.

\section{Objective 2: estimate quantitatively the hydrologic conditions of Calderas watershed through a water budget.}

Characterizing natural interactions within the watershed aid in understanding recharge characteristics of the water source which are necessary to appropriately manage and protect the water supply over time. The primary focus is to approximate recharge and evapotranspiration rates to both: 1) the water source and 2) the basin.

By establishing a water budget, inferences can be made to promote sustainability in the water management of Calderas Lake. Climate records of the basin are needed in order to provide such relations. 


\section{Site location}

The study area is located in the central highlands of Guatemala (Figure 2) about $30 \mathrm{~km}$ south of Guatemala City and its encompassed within the Pacaya volcanic

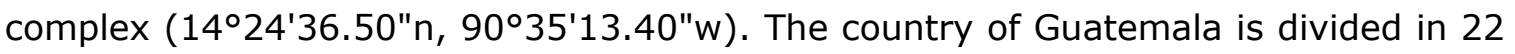
departments, and each department is divided in municipalities (same as states \& counties in the U.S.). Guatemala and Escuintla departments enclose Lake Caldera micro basin. The Calderas community is located $3.5 \mathrm{~km}$ north of Pacaya volcano and its population is more than 1,300 inhabitants. San Francisco de sales host another $\sim 700$ residents within the catchment area, and is the other of the two most influential villages in the Lake Caldera ecosystem (Luis E. Revolorio personal communication). Approximately 7,900 citizens (about 14 communities) live proximal to the volcanic complex and are supplied from Calderas Lake (Fajardo Gil, 2010).

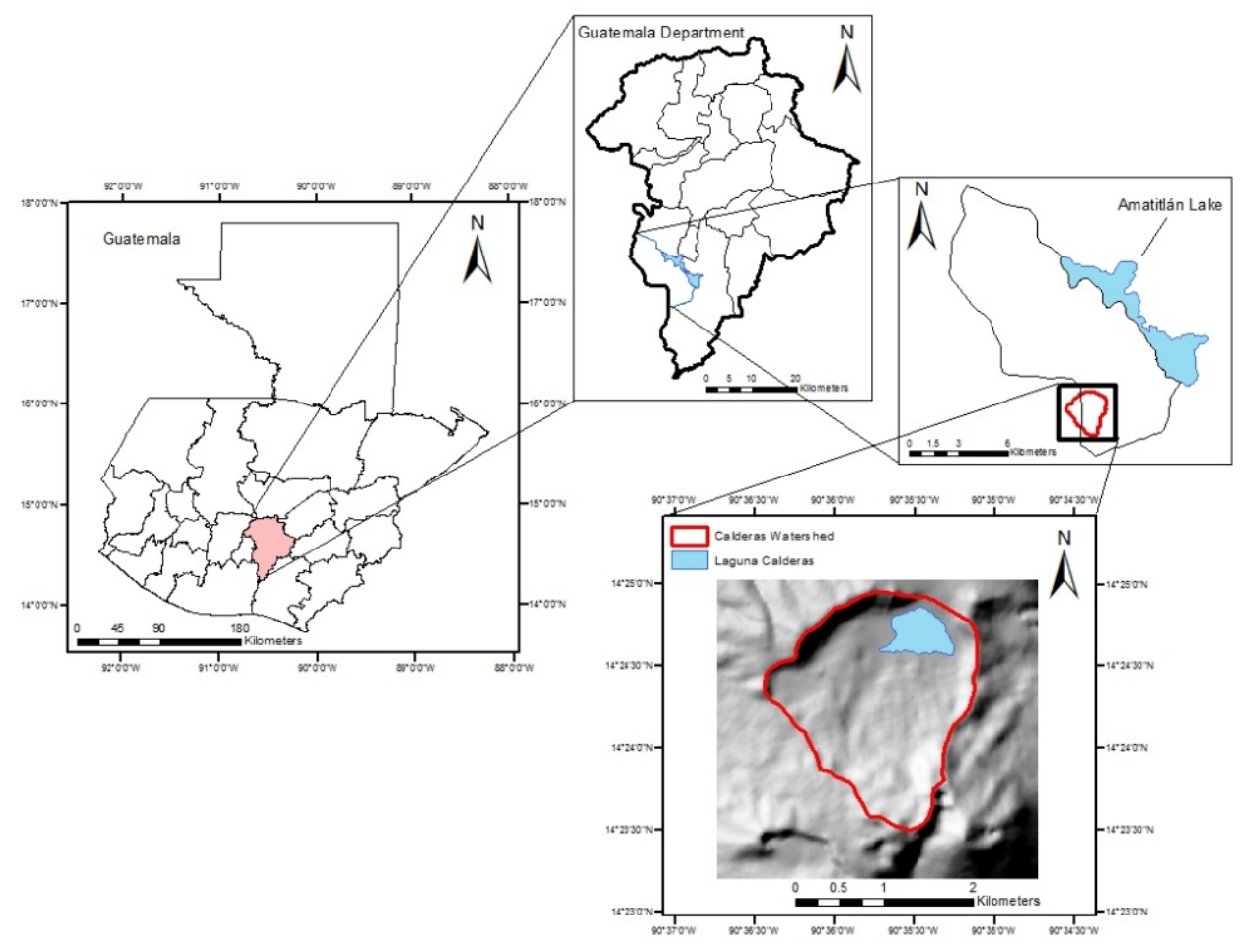

Figure 2. Map of Calderas watershed. 


\subsection{Geological setting of Calderas basin}

Calderas Lake is an inactive crater lake located at the southernmost rim of Amatitlán caldera. Its formation is presumed to be associated with the subduction of Cocos plate beneath the Caribbean plate and the volcanism associated with Amatitlán cauldron Tertiary eruptive history and the Pacaya volcanic complex evolution since Quaternary period (Bardintzeff, 1992; Eggers, 1975; Wunderman \& Rose, 1984).

The formation of Calderas Lake can be summarized by a series of tectonic and volcanic forces that took place between mid to late Pleistocene ( $1.0 \mathrm{ma} \mathrm{bp}$ ) and initial Holocene (< $23 \mathrm{ka}$ ), based on Wunderman (1982) Amatitlán tephra fall geochronology. Magma migration, volcanic eruptions and tectonic forces throughout time sculpted today's landscape placing Pacaya volcano in its current location and exposing Lake Caldera as a geomorphological feature of the volcanic complex (Bardintzeff, 1992; Conway et al., 1992; Eggers, 1972; Gomez et al., 2012; Koch, 1975; Wunderman \& Rose, 1984).

Regionally, Calderas is located $5 \mathrm{~km}$ SW of lake Amatitlán and approximately $11 \mathrm{~km}$ on the same direction to the WNW-striking right-lateral strike-slip Jalpatagua fault zone (JFZ). The crustal extension ( $8 \mathrm{~mm} / \mathrm{yr}$ ) of the Polochic and Motagua leftlateral fault zones to the north and the interaction of JFZ (10-14 mm/yr) through time had formed a series of north-to-south striking grabens, such as the Guatemala City graben (GCG) (Burkart \& Self, 1985; Carr, 1976; Lyon-Caen et al., 2006) (Figure 3a). Previous studies revealed that the absorption of the e-w extensional deformation lead to the volcanic activity related to the Amatitlán caldera eruptive history and further development of the Pacaya volcanic complex to the present dynamics of Pacaya volcano.

Wunderman and Rose (1984) identified a series of north-to-south arcuate normal thrust faults south of Lake Amatitlán. Some of these faults extend to Calderas watershed geographical divide and can be inferred to be inter-connected along the subsurface (Figure 3b). A horst fault feature can be observed NW of Calderas rim (Figure 3c). This structural feature is defined as a body of rock surrounded by fault surfaces completely bounded by a branch-line loop along the surface intersection of two faults (Groshong, 2006). The basal detachment cuts the strata in the opposite direction on the downward block of the fault causing uplift and bending of the igneous units bounded at the intersection of the fault plane (Van Der Pluijm \& Marshak, 2004). 
Based on field observation and literature description, the occurrence of this horst feature can be a mechanism for groundwater seepage to either sides of Calderas rim. Geothermal features and fumaroles are observed on the inner Calderas wall less than $1 \mathrm{~km}$ west of the horse fault at lower elevations (Figure 3c). This structural mechanism can explain the occurrence of intermittent fumaroles ${ }^{2}$ (Aroldo Mijangos, former Pacaya park administrator, personal communication), geothermal features ${ }^{3}$ and a shallow pond $^{4}$ on the east outer wall of Calderas where a smaller rim shapes the impression of a smaller caldera during the evolution of present Pacaya complex. Further reconnaissance should be undertaken to validate the connection and existence of such fault lines with the geothermal features at Laguna el Durazno and Humitos village.

Calderas basin is a horseshoe-shaped amphitheater caldera rim. As its name suggests, is a caldera product of ancient volcanic eruptions that lead to the depression of one of Pacaya's ancestral cones (Eggers, 1972; Pereira Rodas, 1990). Eggers (1972), initially proposed that the first ancestral cone is located in what is named today Cerro Hoja de Queso (N-rim of Calderas Lake). Previous studies had identified a series of phases suggesting a chronological order of events involving the Pacaya volcano evolution and tephra depositions related to ancient eruptive events (Eggers, 1972) enclosing Calderas lake; a) Cerro Grande (2570 masl), b) Cerro Chiquito (2460 masl), and Cerro Chino (2265 masl) to the SW of Calderas Lake (Eggers 1972, Wunderman and Rose 1984, Bardintzeff 1992, Conway et al. 1992) (Figure 2.2b). These cones cover a considerable portion of the southern quadrant of Amatitlán caldera including Calderas Lake. Cerro Grande and Cerro Chiquito were described by Koch (1975) as steep and exogenous andesitic to rhyodacitic domes covered with tephra and pyroclastic from ancient eruptions related to Pacaya evolutive history. The rocks are glassy, often vesicular, and possess a consistency composed of plagioclase phenocrysts (Wunderman \& Rose, 1984). The more silicic dome rocks have biotite, oxyhornblende and plagioclase phenocrysts (Eggers, 1972). No radiometric dating had been performed for these units, nonetheless, previous studies placed them

2 Fumaroles can be observed, however does not occur on a daily regular basis

${ }^{3}$ Soil alteration patches similar to Figure $2.2 \mathrm{c}$ are visually present on Los Humitos village

4 Villagers and locals have observed a shallow pond that over the years. It's known as Laguna El Durazno despite the fact that is dry most of the year.

$$
-9 \text { - }
$$


stratigraphically between $1.27 \pm 0.57$ (tephra unit I) and $-0.3 \pm 0.3$ ma (tephra unit t) (Koch, 1975; Wunderman \& Rose, 1984).

The volcanic product deposited at the north section of Laguna Calderas and above Cerro Hoja de Queso is described as an ancestral andesitic volcano, heavily eroded and covered with no more than $1 \mathrm{~m}$ thickness of tephra from the $\mathrm{J}$ group of Amatitlán Caldera latest plinian fall during the Oligocene \pm 23 ka (Carr, 1984; Eggers, 1972; Koch, 1975; Wunderman \& Rose, 1984).

Recent volcanic products intersect with the ancestral volcano and lava domes units to complete the Calderas Lake geologic series. These products are related to the modern Pacaya volcano and the evolutive magmatic trajectory to its current geographical position (Conway et al., 1992). Eggers (1972), classified the basalt flows of Pacaya volcano as "historic, modern and initial". Further reading on the evolution on Pacaya volcanic complex can be found in the references cited in this section. 


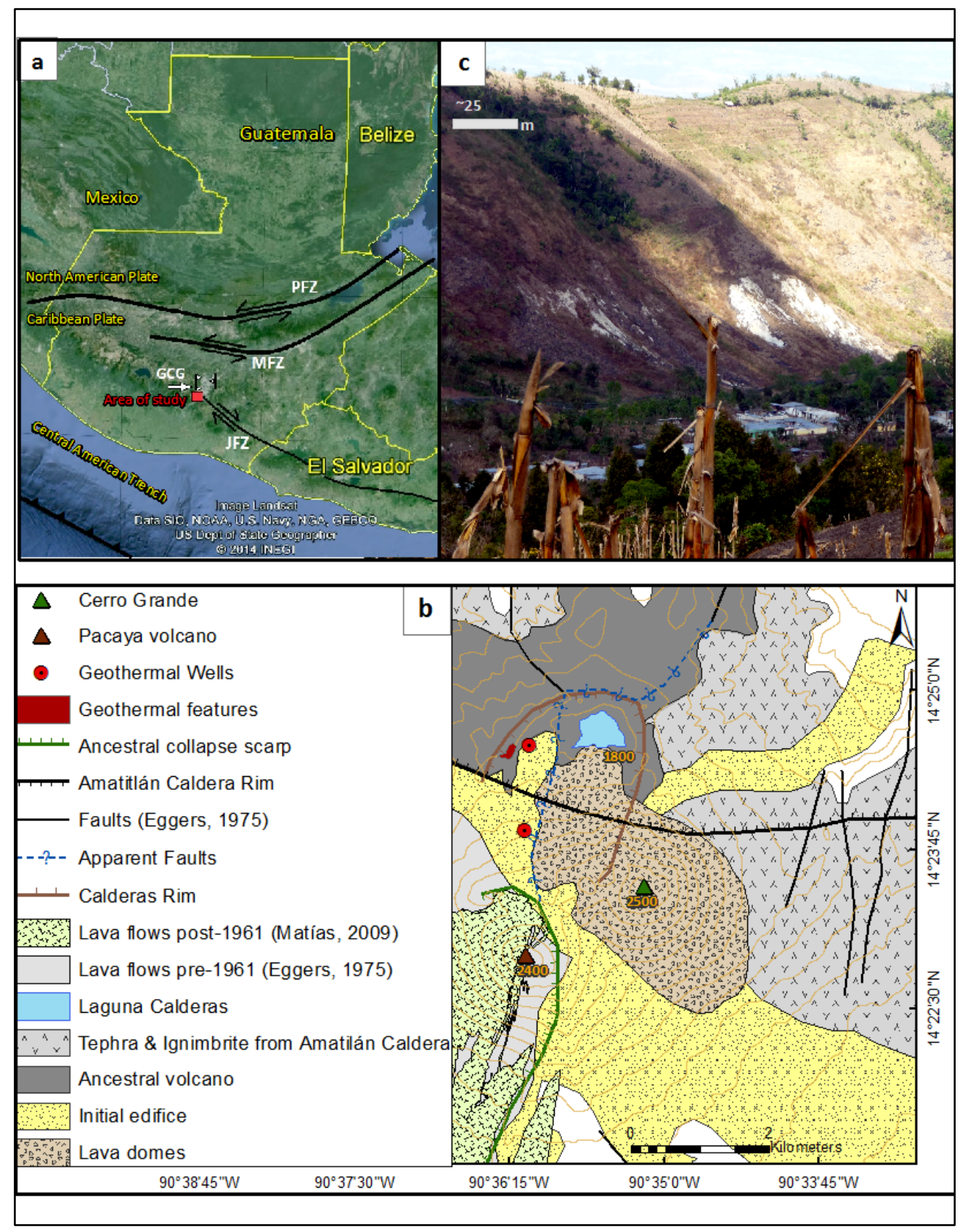

Figure 3. Geologic map of Calderas quadrangle. Location of Calderas Lake and main geological and structural features. a) Laguna Calderas basin is a horseshoe amphitheater caldera rim located just south at the edge of Amatitlán caldera rim. The area is highly affected by the right lateral Jalpatagua fault zone (JFZ) and the extensional zone of the Guatemala City graben. Polochic (PFZ) and Motagua (MFZ) fault zones are located north, separating North American from Caribbean tectonic plates (modified from Burkhart ad Self (1985), Lyon-Caen et al. (2006), and Schaefer et al. 2013)) b) General geology modified from Eggers, (1972) and Wunderman and Rose (1982) c) Fumarole and hydrothermal alteration features at west inner edge of Cerro Hoja de Queso (Calderas rim). Constant fumaroles expose a variety of soil colors and diverse physical soil characteristics indicating a geothermal source at the $\mathbf{W}$ bottom of the rim a part of San Francisco de Sales community. 


\subsection{Geothermal field}

Guatemala has an extensive geothermal reserves estimated to be between 800 to $4,000 \mathrm{mw}$ due to its tectonic location (Capuchino et al., 2008). During the $1970 \mathrm{~s}$ several international agencies assisted Guatemala's Instituto Nacional de Electrificación (INDE) in assessing the countries geothermal resources (Lima Lobato, 2000). Ever since the geothermal potential discovery of the Amatitlán area, the local government has been in negotiations with international companies to promote an alternate form of energy production in Guatemala.

A geothermal power plant has been operating in the area since 2007. The power plant is owned and operated by ORTITLAN Ltd., who installed three turbines generating about 162 GWh (gigawatts) annually producing a monthly rate about $20.5 \mathrm{mw}$ (megawatts) from the Calderas-Pacaya complex (Capuchino et al., 2008). A steam and brine reinjection well is installed about $250 \mathrm{~m}$ w of Calderas Lake. A mineral-rich pond is produced after geothermal reinjection (Figure 4). This pond raised speculation amongst villagers about contamination and potential health damage to the communities produced after the geothermal process. However, curative characteristics and tourism increase are commonly associated with thermal and mineral water from geothermal processes (Borović \& Marković, 2015; Minervini, 2005).

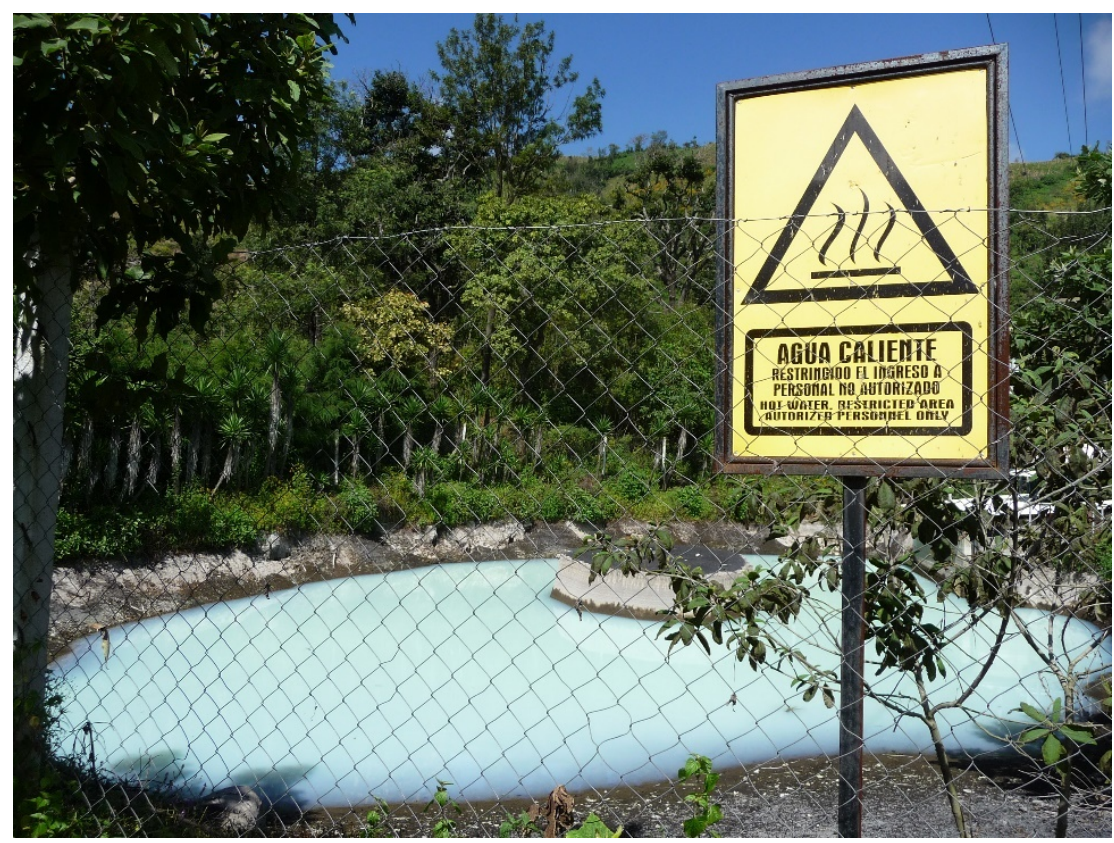

Figure 4. Geothermal wastewater disposal pond, located approximately $\mathbf{2 5 0} \mathbf{~ m ~ W}$ of Laguna Calderas (photo: author). 


\subsection{Potable water infrastructure}

The municipality constructed a water tank and distribution network for the households to the community during the mid-1990s to provide access to water and improve sanitation (Luis E. Revolorio, personal communication) (Figure 5). Prior to the distribution system, the villagers collected their water directly from the lagoon for domestic and agricultural purposes. Despite the access of water to every house in the community, some individuals are still collecting water directly from the lagoon and performing domestic activities threatening lake's ecosystem and water quality.

According to Luis E. Revolorio Peralta (personal communication) -community mayor at time of study-Calderas community was divided in two sections for water distribution. Domestic users stockpiled water in barrels (toneles), buckets, sinks (pilas) to be used on the days where the water is not distributed to either side, which leaves these sources susceptible to contamination (Figure 6). Most houses have one single pipe normally placed outside close to the main path or next to their pilas or toneles.

Domestic activities and interactions from community members with the lake include: laundry, bathing, domestic consumption, livestock consumption, agricultural practices and gardening, water storage, and recreation. These observations were made during my time in site as a Peace Corps volunteer.

The Calderas community tank has a holding capacity of $40 \mathrm{~m}^{3}$ for water storage. It provides water to its residents through a 2.5-inch nominal diameter pipe network. According to Leonardo Castañeda - in charge of the water system and distribution for Calderas tank - (personal communication) the tank reaches maximum storage capacity five times per day at an approximate rate of $200 \mathrm{~m}^{3}$ per day (Figure 7). In order to estimate withdrawals from the community, we must multiply the daily approximate withdrawal rate with monthly service days (26 days, not accounting for Sundays). This, gives an approximate total of $5200 \mathrm{~m}^{3}$ of water distributed to Calderas community on a monthly basis. To establish an estimate consumption rate based on storage tank dimensions, we have converted the storage maximum capacity volumes from cubic meters to liters and divide it by the beneficiaries (1300 inhabitants). According to this simple arithmetic analysis, the daily consumption rate for Calderas inhabitants is 154 liters per day. Observations made to my host family during time in site led to establish a comparative relationship for estimating water consumption 
volumes for Calderas community. Generally, there are three toneles used as water storage containers for a household of six members. The water from these containers is used for domestic activities mentioned previously. Each tonel has a $60 \mathrm{~cm}$ diameter and a height of $90 \mathrm{~cm}$. When calculating for the area of a cylinder we obtain that each tonel holds approximately 254 liters of water. With this volume in mind, one can assume that each family of six that uses three toneles would have 763 liters of water available on a daily basis. If water usage is distributed evenly to all household members (6), a daily usage of 127 liters per person is estimated. Volumes between the community storage tank (154 liters) and household storage (127 liters) differ by 27 liters which can be assumed to be attributed to water spill when filling up storage containers when are left unattended for a certain amount of time or to other unquantifiable sources of storage such as buckets, pilas and other water storage devices. Typically, a family member begins filling up their storage containers, continue working on their chores and by the time they switch the water hose to the next container water has been already spilled to the ground.

Chlorination is the only method of potable treatment from municipal authorities prior to distribution and therefore consumption. Concentrations of $\mathrm{HClO}$ - as the only disinfection method - added to the water prior to distribution were estimated to be $2.92 \mathrm{mg} / \mathrm{l}$ chlorine equivalent at Calderas storage tank on a daily basis (Villagrán, 2012). If these concentrations stay consistent, the distributed water is acceptable for consumption (COGUANOR, 1999). Thus, previous studies found that chlorine concentrations decreases as water travels away from their source of distribution (Villagrán, 2012). 


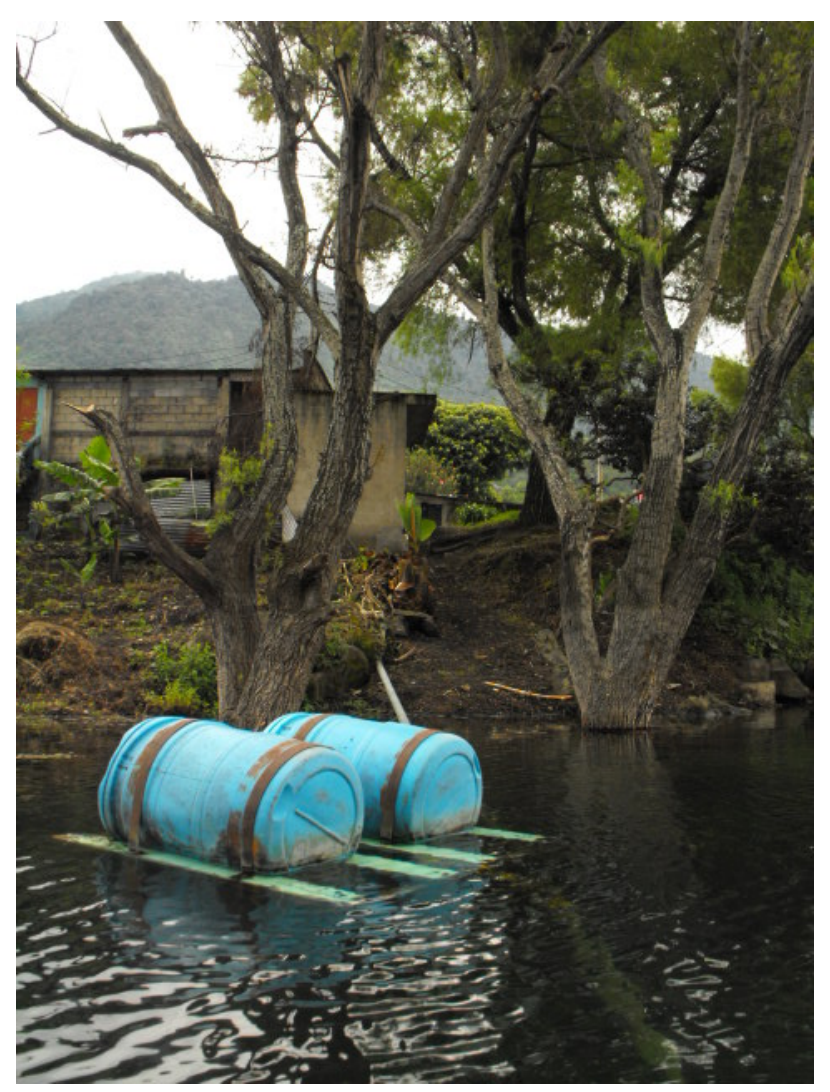

Figure 5. Calderas community intake. Pumping rate reaches an approximate of $200 \mathrm{~m}^{3}$ per day (photo: author).

Water used for agricultural practices was difficult to quantify at the time of study. Typically, farmers - those whose land is not within the community perimeter fertilize their crops during dry season and use the rainy season as main water input to their crops.

In addition to the Calderas community water intake, two other water intakes are located at Calderas Lake for water extraction and distribution to other communities outside the watershed. Pumping rates and tank storage volumes for the remaining intakes were difficult to address due to inadequate monitoring. Members from other communities were responsible for the water distribution and pump functionality. At the time of study, no contact was made with such individuals. With an urban population approaching 1300 inhabitants, Calderas community has an estimated consumption rate of $150 \mathrm{l} /$ person/day as estimated above. 


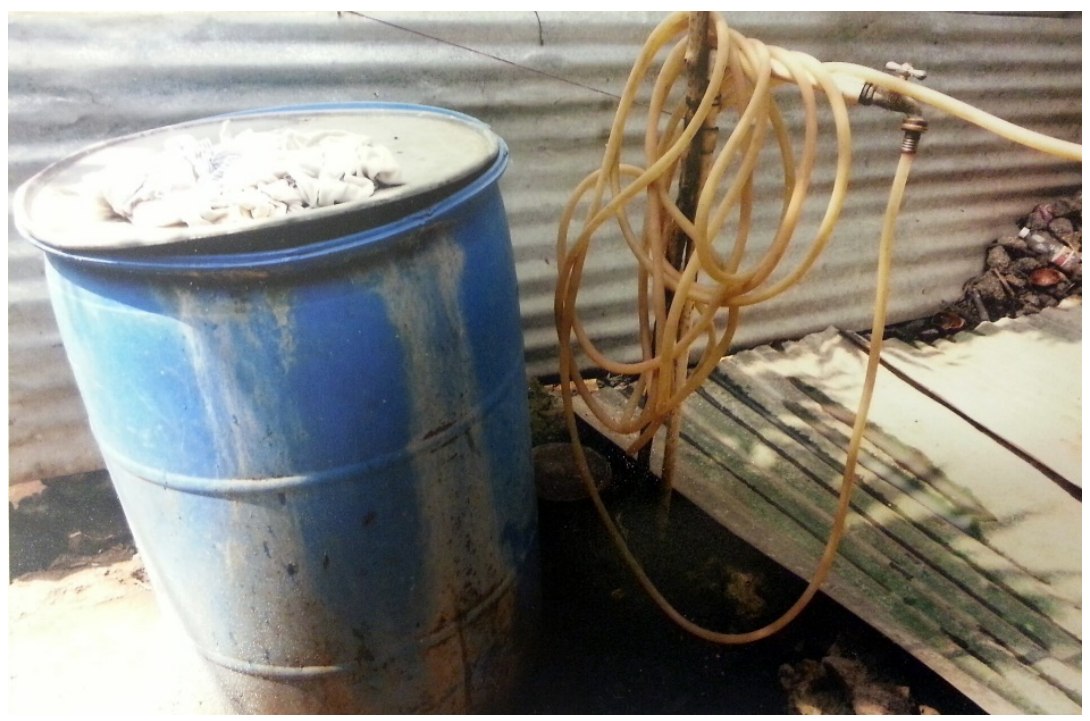

Figure 6. Common household water storage barrel or tonel and distribution pipe (photo: author).

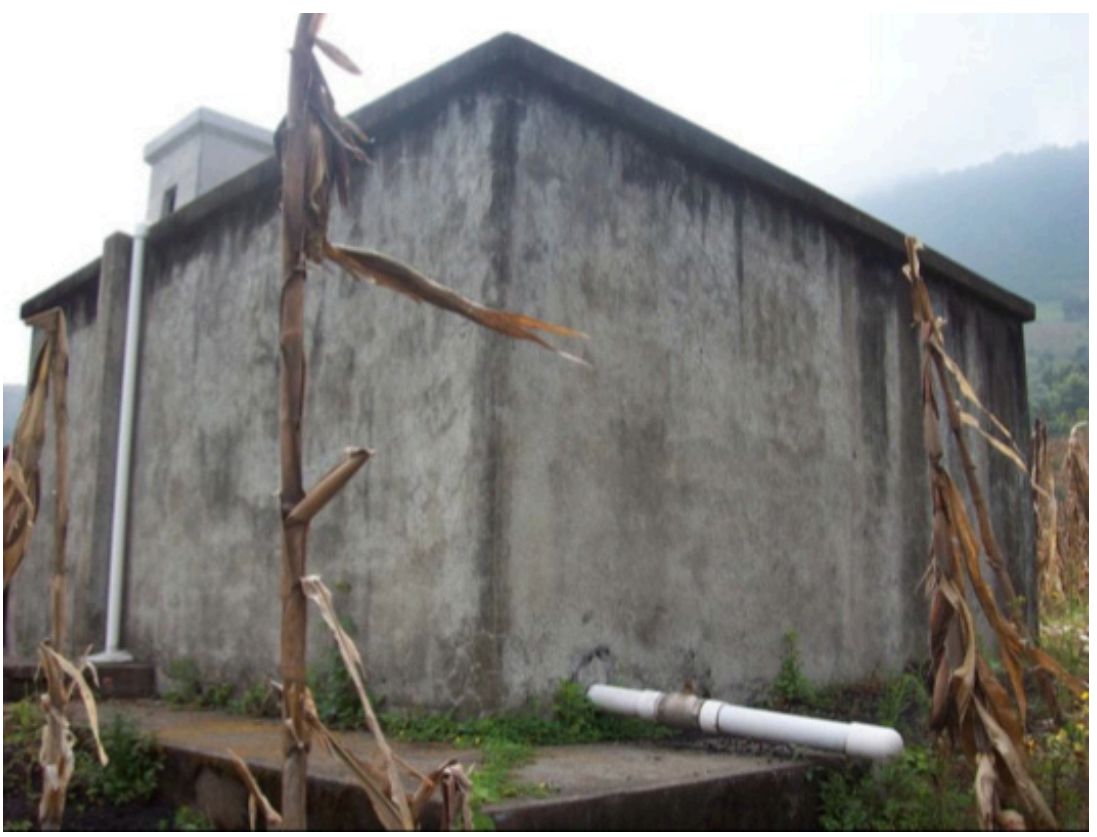

Figure 7. Calderas community water storage tank for gravitydistribution system (photo: author). 


\section{Methods and fieldwork}

\subsection{Spatial analysis}

It is known that watershed hydrology depends on factors such as land use, climate, and soil conditions. However, the relative impacts of the land use on the surface water are important for assessing the input and output contributions of a watershed. Both statistical and geographic information systems (GIS) analyses were used in this study. These were used to examine the relationship between the land use and water quality for locating contamination sources and estimate a water balance for Calderas watershed. ARCMAP GIS analyses were applied within this research to aggregate, synthesize, and analyze small databases to identify spatial relationships among such components.

Calderas watershed is located within the Maria Linda river basin (Figure 8). Twenty seven municipalities from four departments (states) are supplied by the Maria Linda basin, which occupy $11 \%$ of the pacific drainage area covering $2.4 \%$ of Guatemala's surface area (M.A.R.N., 2011).

Calderas microbasin ${ }^{5}\left(4.1 \mathrm{~km}^{2}\right)$ is located south of Amatitlán lake, at the very edge of the division from the upper Michatoya River, lower Michatoya River and María Linda River basins. It is enclosed by the Pacaya volcanic complex at elevations ranging from 1798 - 2457 masl, has a mean slope of $31^{\circ}$ and perimeter of $8.1 \mathrm{~km}$ (Table 1 ). The drainage pattern is presumably closed, due to its elevation and shape in relation to its volcanic precedent with the Pacaya volcanic complex (García García, 2002). The

only surface water reservoir at Calderas micro-basin is Calderas Lake $\left(0.25 \mathrm{~km}^{2}\right)$ with an approximate maximum depth of $28 \mathrm{~m}$ in its center and an approximate mean depth of $12 \mathrm{~m}$ (Lira Prera, 2005; Marroquín Guerra, 2008). Presumably, the bathymetry of the lake had changed after the eruption of Pacaya during May 27, 2010 due to the amount of ash, ballistics and volcanic debris that fell during the event. Thus, no recent study has addressed that issue. Heavy rains from hurricane Agatha on May 28, 2010 transported most the volcanic ash and debris into the lake, and a landslide dragged

${ }^{5}$ I am defining a "microbasin" in this work to be a small hydrological catchment with a nearly flat bottom surrounded by low bunds that drains water to a common center. - 17 - 
the material affecting the local school and several houses at the shore of the lake (Luis E. Revolorio Peralta, personal communication).

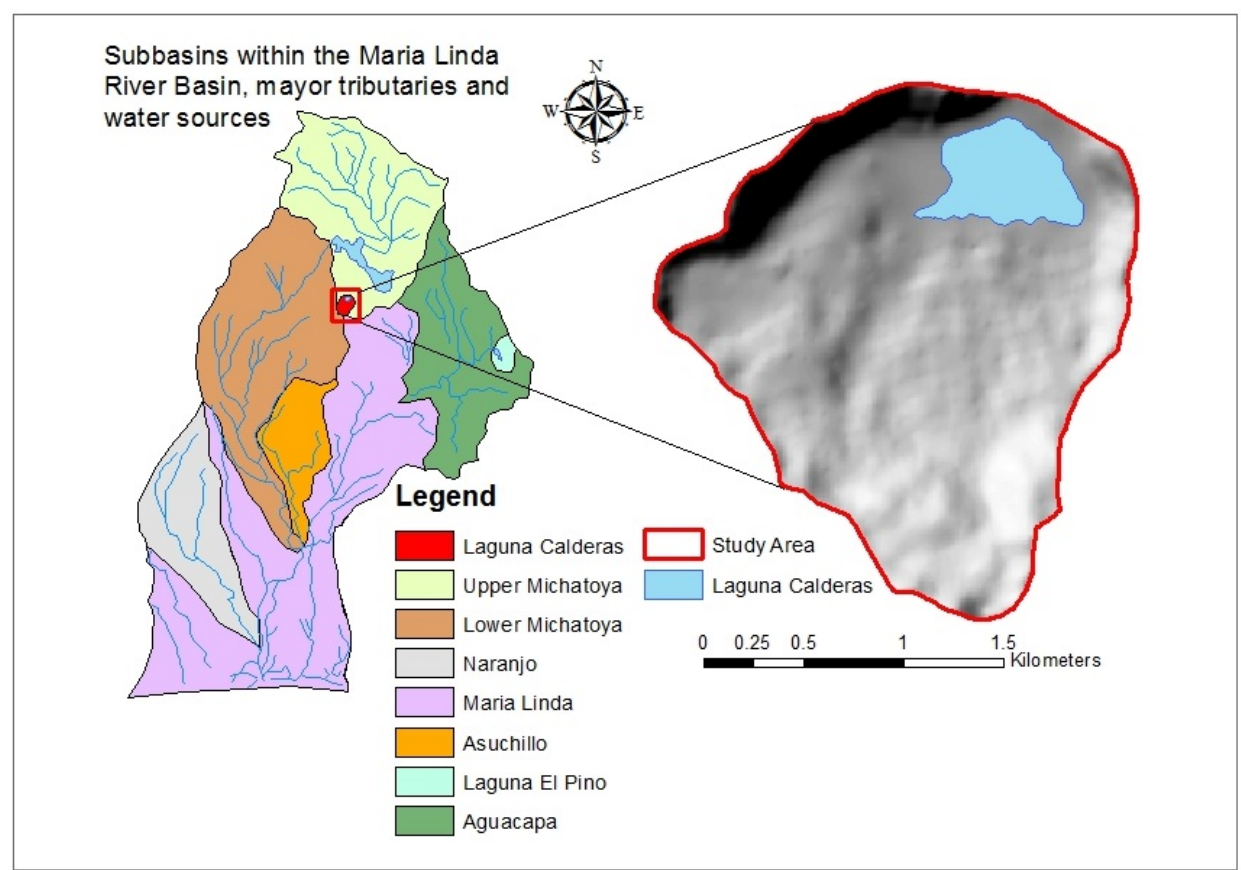

Figure 8. Maria Linda river basin, sub-basins, tributaries and surface water bodies. Note the lack of tributaries at Calderas watershed.

Table 1. Morphometric parameters of Calderas watershed.

\begin{tabular}{|c|c|c|}
\hline \multicolumn{3}{|c|}{ Morphometric parameters of Calderas watershed } \\
\hline Description & Unit & Value \\
\hline Lagoon area & $\mathrm{km}^{2}$ & 0.25 \\
\hline Basin area & $\mathrm{km}^{2}$ & 4.1 \\
\hline Perimeter & $\mathrm{km}$ & 8.1 \\
\hline Max elevation & masl & 2457 \\
\hline Min elevation & masl & 1798 \\
\hline X centroid & $\mathrm{m}$ & 490 \\
\hline Y centroid & $\mathrm{m}$ & $1.6 \mathrm{e}+06$ \\
\hline Z centroid & masl & 2096 \\
\hline \multicolumn{3}{|l|}{ Altitude } \\
\hline Mean altitude & masl & 2096 \\
\hline Frequent altitude & masl & 1798 \\
\hline $1 / 2$ frequent altitude & masl & 1985 \\
\hline Mean slope & degree & $31^{\circ}$ \\
\hline
\end{tabular}

$-18-$ 
The surface extent of Calderas micro-basin partially encompasses the San José Calderas and San Francisco de Sales villages. San José covers an area of $3.35 \mathrm{~km}^{2}$ and San Francisco $0.75 \mathrm{~km}^{2}$, corresponding to $85 \%$ and $15 \%$ of the community geographical land coverage, respectively (Marroquín Guerra, 2008).

The geomorphology of the region was interpreted from geological and topographical maps from previous cited literature. The topographic catchment of Calderas watershed is $4.1 \mathrm{~km}^{2}$. No visible streams drain into Calderas Lake due to its higher elevation and volcanic setting. Consistent elevation gradients are found upon reaching the upper region of the watershed (Figure 9).

A hypsometric curve was developed from a 10-m digital elevation model (DEM) for Calderas area after GIS analyses. The mean altitude of the watershed is $2096 \mathrm{~m}$ above sea level and it corresponds to $1 \%$ of the total area. Lower elevations have higher percentages of land distribution within the watershed. The elevation frequency shows the interval percentages of lower to higher elevations constrained by increasing slope. Relating these values to population settlements, we can deduce that inhabitants within the watershed are settled within $1790 \mathrm{~m}$ - $1950 \mathrm{~m}$ above sea level. Slope increase and soil conditions are limiting factors for inhabitants to continue uphill expansion.

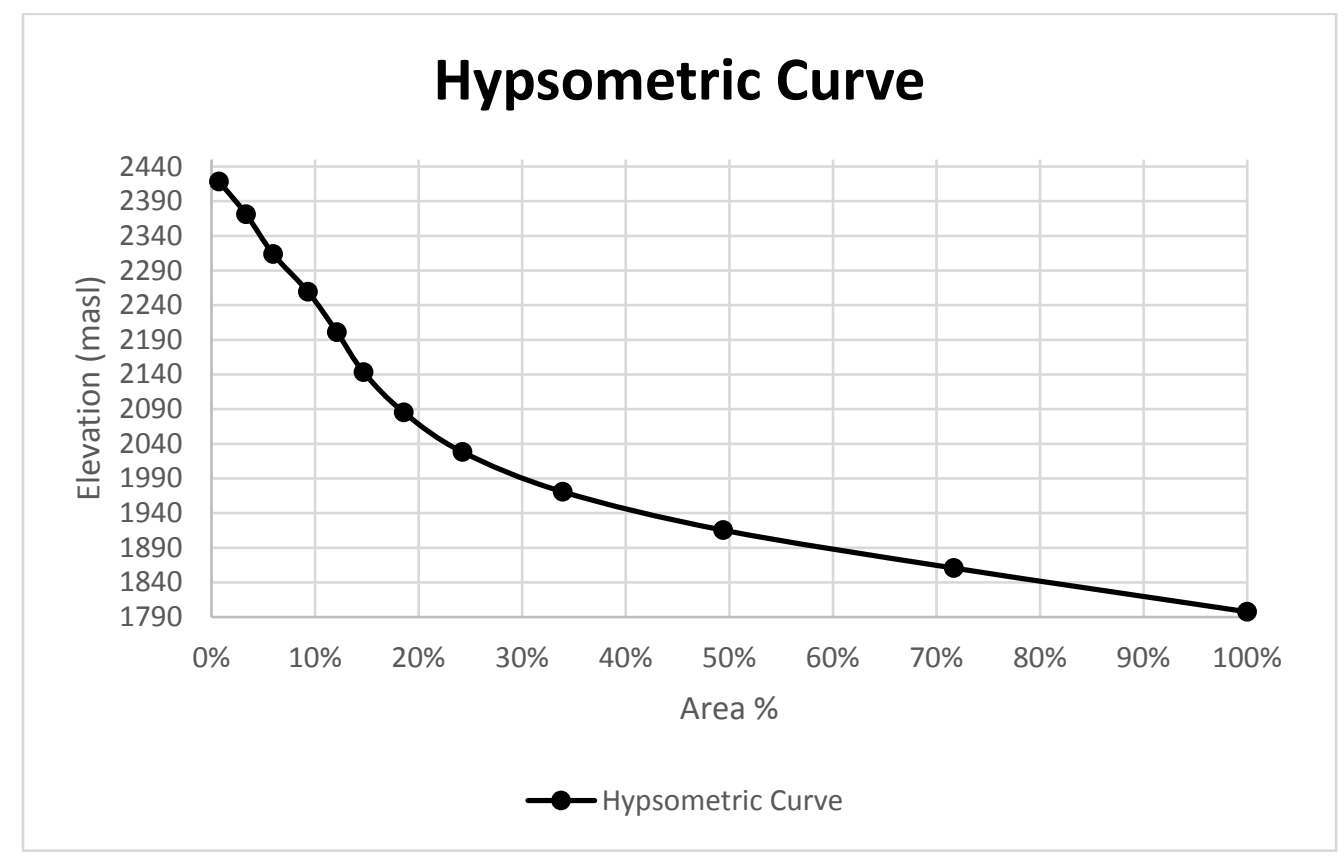

Figure 9. Hypsometric curve of Calderas watershed. 


\subsection{Water balance}

Calderas Lake interacts with the atmosphere, subsurface, and other surfacewater features. The lake gains water from rainfall and groundwater seepage and surface runoff. Therefore, loses water by evaporation, evapotranspiration, and extraction for community distribution. Changes in storage between wet/dry seasons are reflected in changes in lake surface elevation (stage) and groundwater table elevations, neither of which are monitored. Under wet conditions, the lake also gains flow from overland runoff, a difficult parameter to account for in the water budget because there is no method available to measure the volume for such input. Also, the existence of several wells used for geothermal energy production within the basin raise more questions about hydrogeological characteristics of the basin. Those parameters were unable to be addressed.

Water balances are key elements of water awareness campaigns and are essential tools for stakeholders involved in decision making over the water resources of a certain area. These water assessments help estimate water availability over a watershed applying the principle of mass conservation accounting for the equilibrium on the amount of water stored in a basin. In order to evaluate the relationship of inputs and outputs of a basin for determining water storage and availability, authorities must establish and define measurable parameters and implement consistent methods. In other words, the amount of water entering, leaving, and storing within Calderas microwatershed needs to be assessed. A water balance is our best tool for answering such important inquiry. This water balance is expressed with the following equation defining the change in storage.

$$
P+G_{i}-E T-R-E_{L}-G_{O}-W_{c}=\Delta s
$$

Where:

$$
\begin{array}{ll}
\mathrm{P}=\text { precipitation } & \mathrm{E}_{\mathrm{L}}=\text { lake evaporation } \\
\mathrm{G}_{\mathrm{i}}=\text { groundwater inflow } & \mathrm{G}_{\mathrm{o}}=\text { groundwater outflow } \\
\mathrm{ET}=\text { evapotranspiration } & \mathrm{W}_{\mathrm{c}}=\text { community withdrawals } \\
\mathrm{R}=\text { runoff } & \Delta s=\text { change in storage }
\end{array}
$$


Conceptually, this water budget is the sum of all inputs minus the outputs of a watershed. Therefore, precipitation falling on the watershed flows overland, infiltrates the soil, and recharges the aquifer that feeds the lake and evapotranspires back to the atmosphere. Natural forest canopy and cultivated crops aid in this last process. Groundwater outflow -or seepage- is a difficult parameter to quantify. Henceforth, it is not accounted for within the water balance simulation. Lake evaporation is an important component estimated within the model. It can be accounted as a fraction of the surface water that evaporates back to the atmosphere from the lake. Human activity has a strong influence in the area, estimated community withdrawal volumes are subtracted from the water balance.

Groundwater recharge and surface water inflow are jointly referred to in this study as net precipitation. Net precipitation is multiplied over the basin and lake's area to determine potential recharge volumes. Several assumptions must be made in order to solve for net precipitation. Based on the available data, the model is subject to these assumptions:

i. Precipitation is the only recharge mechanism into the subsurface. Hence, groundwater inflow is assumed to be negligible; subsurface geology mimics topography (Dingman, 2002).

ii. Seasonal variability and water extraction affects lake volumes for Caldera's Lake. Therefore, the quantities are represented by long term averages by selecting start/end periods at times when values are anticipated to be similar, such as the watershed's maximum storage potential.

iii. The water intakes at the lagoon extract the same amount of water on a monthly basis. Hence, water extraction is considered as an output and is subtracted from the estimated recharge volumes of Calderas Lake.

This research applies some of water balance principles presented by Dingman (2002) to Calderas watershed using the Thornthwaite-Mather monthly water balance method for assessing groundwater recharge and estimate lake recharge volumes for establishing a baseline hydrological overview of such important system. The components of this method are explained later in this section.

Tropical climate dominates Calderas region where seasonal variation is distinctively marked by precipitation. Much of the precipitation occurs during the -22 - 
months of May through October where mean seasonal precipitation reaches $245 \mathrm{~mm}$. Meanwhile, the dry season spans from November through April with an average 60 $\mathrm{mm}$ of rain. Mean annual precipitation for Calderas watershed can reach up to 1600 $\mathrm{mm}$ on a wet rain year. Storm events during wet season occur frequently (daily), and the latter have moderate rainfall intensities and typically last from hours to days. These events tend to be less frequent (once a month) and short-lived (less than an hour) having either high or very low intensities during dry season. Based on such characteristics Lira Prera (2005) defined Calderas climate as Subtropical Humid Forest using the Holdridge zone classification system.

In order to characterize the dynamics of a watershed, climate records must be essential criteria for overcoming such analysis. Since, there were not any available weather stations on site, data was retrieved from www.awhere.com. Weighted average of monthly precipitation was calculated based on the nearest station distance against the elevation difference from the watershed. The nearest station is located at INSIVUMEH headquarters near La Aurora International airport at 1489 masl. The elevation difference is then added as a factor for the mean monthly precipitation averages. These monthly averages were multiplied by 1.72 as the weighted elevation coefficient, then used as inputs into a water balance model to establish depictive weather impacts to the aquifer recharge in relationship to estimated lake volumes.

Mean monthly precipitation records are summarized in Appendix A. Climate records were retrieved from www.awhere.com. This weather platform interpolates near-real time, high-resolution weather data with global meteorological stations for approximating precipitation values over a certain area. This data source was selected due to the gaps found on INSIVUMEH web datasets. aWhere provided continuous data for the study period.

Historical (2009 - 2015) mean monthly precipitations and temperatures were modelled from available data, shown on Figure 10. During time in site, depth measurements of the lake were recorded over a six-month period. Therefore, it was chosen to select a climate analysis window for verifying its input in contrast to lake depth measurements. Figure 11 shows monthly rainfall accumulates and mean 
temperatures from June through December 2012. Two water balances are modelled; 1) based on historical climate data, and 2) a seasonal window from time in site.

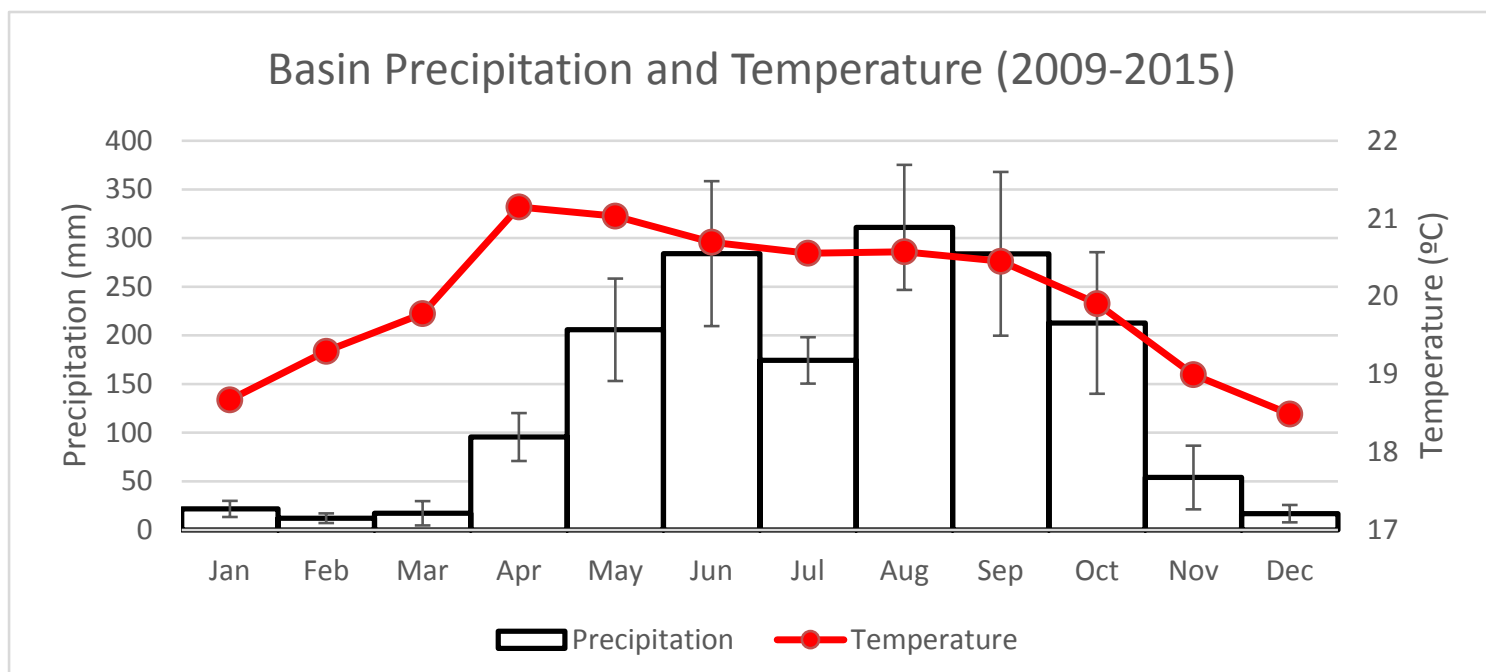

Figure 10. Adjusted mean annual precipitation $(\mathrm{mm})$ dataset for Calderas catchment from 20092015 period. Vertical bars represent the standard deviation of the means. (source: www.aWhere.com)

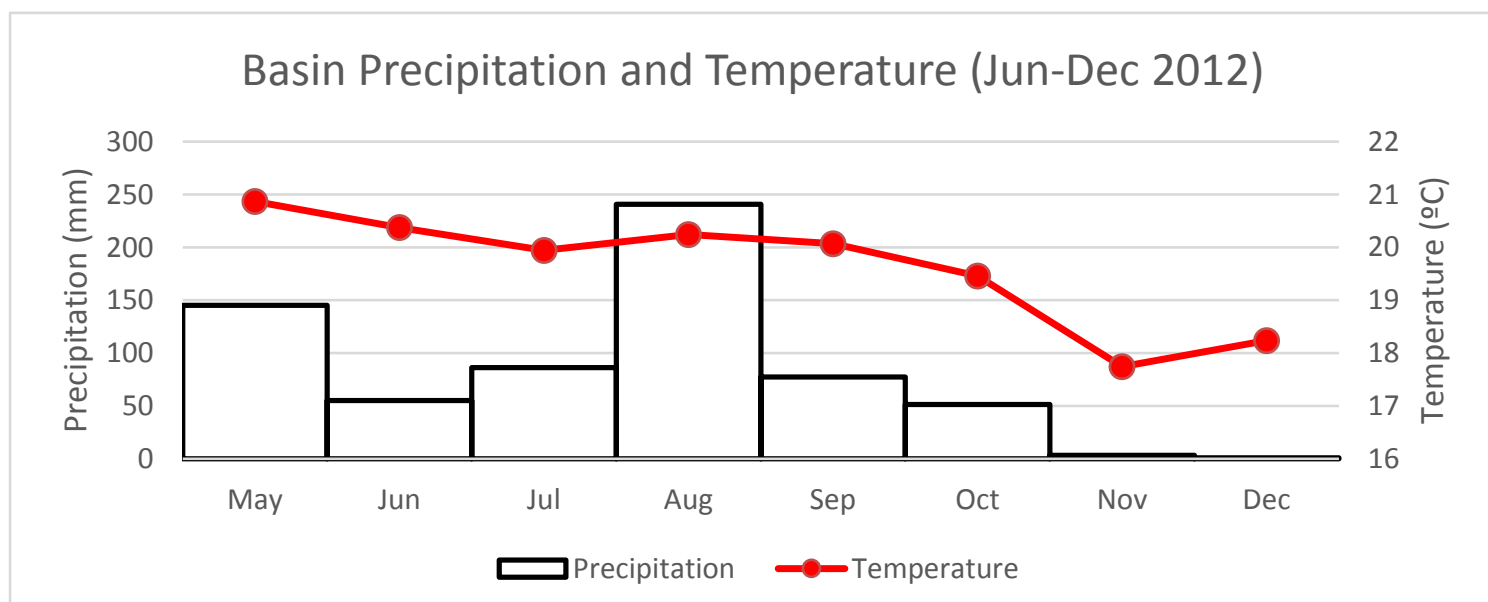

Figure 11. Adjusted mean annual precipitation $(\mathrm{mm})$ for Calderas catchment from 2009-2015 period. Vertical bars represent the standard deviation of the means. (source: www.aWhere.com) 


\subsection{Potential evapotranspiration}

Evapotranspiration is an important parameter that deserves special attention for watershed management schemes. It can be defined as the amount of water that would be evaporated under ideal climatic conditions, hence considered as an unlimited water supply. If water demand exceeds its availability, soil moisture depletion occurs and eventually plants die. Many methods have been tested elsewhere for estimating potential evapotranspiration, which have been classified in many groups (Allen et al., 1998; Rosenberry et al., 2007; Xu \& Singh, 2001) depending upon on the available data for modelling estimation. Based on our available data, a temperature group equations were selected to estimate evapotranspiration for developing a benchmark water budget for Calderas lake micro-basin.

\subsubsection{Thornthwaite-Mather method}

A basic watershed-scale water balance model modified from Dingman (2002) was used to analyze and simulate the behavior of water in the downslope watershed. This model uses basic procedures for examining the water distribution over a hydrologic system (Thornthwaite, 1948) by lumping calculations of root-zone depths and soil capacities over a homogenous catchment. Ultimately, the model estimates the available water in the system based on net precipitation and soil moisture generating an outflow in response to the aquifer discharge into the lake (Figure 12). The model assumes that when saturated soils exceeds the soil capacity, surplus water percolates downward by gravity below the capillary fringe (root zone) and gets stored in the aquifer. Aquifer to lake potential annual recharge was modelled using the TMWB from available data on regional climatic conditions. The estimated values were then analyzed to provide percentages of inflows and outflows to contrast water availability and water use over Calderas Lake.

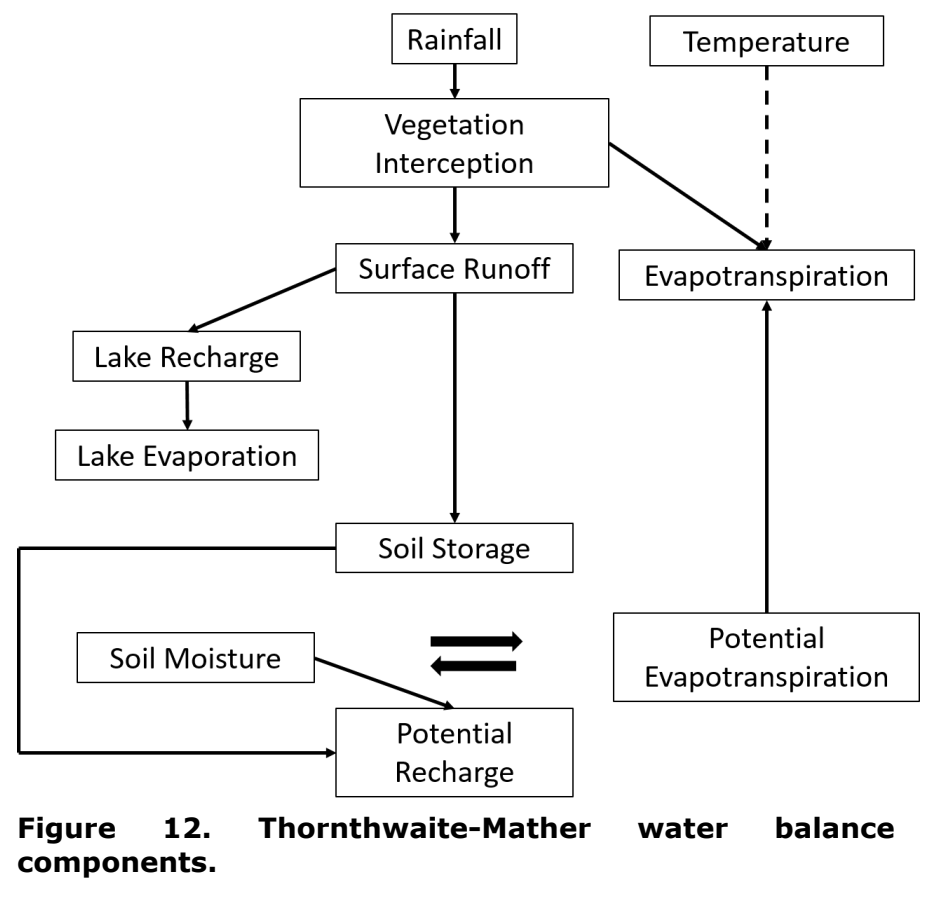


This method is best suited for estimating a water budget for Calderas basin due to its simple relation for computing and estimating monthly evapotranspiration in assessing potential groundwater recharge and estimating lake volumes from climate changes on localized hydrologic cycles (Alley, 1984; Lu et al., 2005; Westenbroek et al., 2010).

The model version applied in this study employs three temperature based methods; one implemented by Hamon (1963) (eq. 7) to solve for evaporation from potential evapotranspiration, the Blaney-Criddle (1950) method (eq. 8), and the Papadakis methods (1961) (eq. 9) to estimate lake evaporation within the water budget. In order to estimate monthly recharge $\left(R_{m}\right)$, the required inputs for this model are: precipitation $(P)$ : temperature $(t)$, latitude of the watershed $(\lambda)$, root-zone thickness $\left(z_{r z}\right)$, and soil field $\left(\theta_{f c}\right)$ capacity (Alley, 1984; Rao et al., 2011; Shonsey, 2009). This method relates day length (based on latitude and month) and $t$ to estimate monthly potential evapotranspiration (PET). The $P E T$ is defined as the maximum value obtained from evapotranspiration in wet-soil conditions. If $p$ and soil moisture provides enough water, then actual evapotranspiration $(A E T)$ will equalize PET. Otherwise, the Hamon method estimates AET from PET. Once, the field capacity of the soil is exceeded -the difference between $P$ and AET- the excess becomes net precipitation, which is considered to be the contributing recharge amount. Surplus water stored as soil moisture at the end of the month is carried over to the next month.

The following equations support the Thornthwaite-Mather balance are adapted from (Shonsey, 2009):

$$
R_{m}=P_{m}-\delta s o i I_{m}-E T_{m} \text { Error! Bookmark not defined. }
$$

$$
\begin{gathered}
R \text { if } P_{m} \geq P E T_{m} \text { then } E T_{m}=\begin{array}{r}
P E T_{m}, \text { but if } P_{m}<P E T_{m} \text { Error! } \\
\text { Bookmark not defined. }
\end{array} \\
\text { then } E T_{m}=P_{m}-\delta \text { soil } l_{m}
\end{gathered}
$$




$$
\Delta \text { soil }_{m}=\text { soil }_{m}-\text { soil }_{m-1}
$$

Error! Bookmark

not defined.(4)

Soil $_{m}=$ soil $_{m-1}\left[\exp \left(-\frac{P E T_{m}-P_{m}}{S O I L_{\max }}\right)\right]$ Error! Bookmark not defined.

Soil $_{\max }=\theta_{f c} Z_{r z}$

Error! Bookmark

not defined.(6)

Where:

$R_{m}=$ monthly recharge $(\mathrm{mm})$

$P_{m}=$ monthly precipitation $(\mathrm{mm})$

$P E T_{m}=$ monthly potential

evapotranspiration $(\mathrm{mm})$

$E T_{m}=$ monthly actual

evapotranspiration $(\mathrm{mm})$

$\Delta$ soil $_{m}=$ monthly change in soil

moisture $(\mathrm{mm})$

*calculations begin with soilm-1 as equal to soilmax.

Apart from site coordinates within the TMWB, the model equation requires the dividend between the daylight hours per month and the total annual daylight hours. The coefficient $\Theta_{f c}$ depends on the vegetation type, location and season. According to Xu \& Singh (2001), $k$ coefficients ranges from 0.5 for orange trees to 1.2 for dense natural vegetation. A $\Theta_{f c}$ coefficient of 0.5 is used in the TMWB equation based on a computed NDVI value for crops (25\% land coverage) around the basin. 


\subsubsection{Soil parameters}

Ministerio de Agricultura, Ganaderia y Alimentación (MAGA, 2000) describe soils based on USDA soil taxonomic classifications at Pacaya volcanic complex to be Andisols with Ustand and Vitrand suborders. According to the USDA (1999) soil taxonomy classification, Andisols are soils developed by volcanic ejecta (such as volcanic ash, pumice and lava) and/or volcaniclastic materials dominated by shortrange-order minerals with low apparent density ( $<0.9 \mathrm{~g} / \mathrm{cc}$ ). One of the most dominant processes occurring in Andisols is weathering and transformation of aluminosilicates to the point of formation of short-range-order minerals such as: allophane, igmollite, and ferryhydrite (Lira Prera, 2005). These minerals aid Andisols to be soils of high natural productivity that favor the growth of a wide variety of plants where considerable precipitation results in volcanic soils to be highly fertile. High phosphate retention ( $>85 \%$ ) is a characteristic of these soil types to be a limiting factor when used for agricultural practices (USDA, 1999).

Soil suborders within the area have also been identified as Ustand and Vitrand (Ministerio de Agricultura, 2000). Ustands are Andisols that are more or less well drained in sub-humid regions were grass, shrubs, and forest vegetation dominate the landscape. Some physical characteristics are: warm soil temperatures, less than $15 \%$ of water retention when dry (from 90 to 180 days) and less than $30 \%$ when moisture is present (mostly within rainy season $\sim 180$ days) through $60 \%$ or more of the thickness from the mineral soil surface (Ministerio de Agricultura, 2000).

Vitrands can be found at the very top of the soil column (Figure 13). These are described as relatively young soils occurring near volcanoes with more or less well drainage rates and coarse textured product of recent volcanic ejecta such as volcanic ash and tephra, which is mainly composed of medium to well sorted volcanic glass (Ministerio de Agricultura, 2000). 


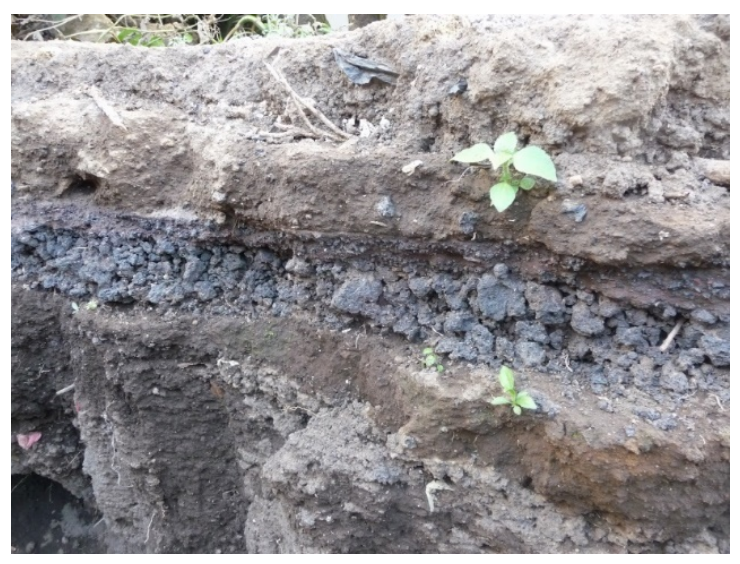

Figure 13. Observed soil horizons at Calderas basin. Andisol b horizon at the bottom, Vitrand A horizon (notice volcanic glass and lapillis) and Andisol $O$ horizon at the very top (photo: author).

The eruption of May 29, 2010 of Pacaya volcano deposited about $\sim 8 \mathrm{~cm}$ of tephra around the Calderas watershed area (Rüdiger Escobar personal communication). The geologic setting and recent volcanic events contrasts with the soil descriptions for the area.

Much of the natural forest has been deforested and removed for agricultural practices and firewood. The land-cover corresponding to Calderas basin is mostly annual and perennial crops, natural shrubs, mixed broadleaf forest, conifers and minor cypress patches (AMSA 2003). The annual crops observed at the basin area are: corn, beans, coffee, avocadoes and vegetables to a minor extent where slope is not a limiting factor. The agriculture practices are traditional type and is mostly used for subsistence among the villagers and not for industrial purposes.

A normalized difference vegetation index (NDVI) was calculated to delineate the land cover of the catchment area (Figure 14). The normalized difference vegetation index is calculated by combining satellite images that have wavelengths surface reflectance in the visible ( $\lambda \sim 0.6 \mu \mathrm{m}$, "red-band") and the near infrared, IR $(\lambda \sim 0.8 \mu \mathrm{m})$ regions of the spectrum using $\operatorname{ArcGIS}^{\circledR}$ software. A set of images from satellite eo-1 ALI were retrieved from USGS Earth Explorer ${ }^{6}$ website, analyzed for further estimation

${ }^{6}$ EO-1 ALI images correspond to January 31, 2011 and January 26, 2013. Source: http://earthexplorer.usgs.gov/ 
of the land cover area and compared it with the observed land use of the area during the time in site. Band combination is governed by the following equation:

$$
\text { NDVI }=\frac{R_{N I R}-R_{V I S}}{R_{N I R}+R_{V I S}}
$$

\section{Error! Bookmark}

not defined.(7)

Where $R_{N I R}$ And $R_{V I S}$ refer to the reflectance values averaged from spectral radiances of wavelength measured by the near-infrared channel and the visible channel of the satellite. Theoretically, this definition does not account as an integral physical quantification, but rather correlates physical properties of leaf area index, fraction cover and biomass. Typically, NDVI calculations have values ranging from -1 to 1 defining areas from null to low vegetation cover $(-1<x<0)$ and very low to dense vegetation cover $(0.1<x<1)$ (Brown et al., 2006). Negative values relate to areas of no vegetative cover, therefore increasing values up to 1 can be interpreted for different types of vegetation for a given area (Carlson \& Ripley, 1997). Different applicable methods approach different values based on satellite image processing and model integration of further inspection. A diversity of methods and applications can be found in (Wang et al., 2005) bare soil values, generally range from $-0.1-0.2$, crop values range from $0.3-0.5$ and dense vegetation range from $0.6-1.0$ (Brown et al., 2006; Carlson \& Ripley, 1997; Janetos \& Justice, 2000). Land cover values for Calderas basin are shown on table 2 . Figure 15 and figure 16 visually represent the land cover extent of the watershed. Note the similarities between the NDVI cover extent and vegetative cover from visual observation.

Table 2. NDVI values for land cover approximation for GIS analysis of Calderas watershed.

\begin{tabular}{|c|c|c|c|}
\hline \multirow{2}{*}{ Classes } & \multicolumn{2}{|c|}{ NDVI values } & \multirow{2}{*}{ Interpretation } \\
\cline { 2 - 3 } & Min & Max & \\
\hline 1 & $\begin{array}{c}- \\
0.0171\end{array}$ & 0.1016 & $\begin{array}{c}\text { Bare soil/ } \\
\text { surface water }\end{array}$ \\
\hline 2 & 0.1016 & 0.2902 & Grass \\
\hline 3 & 0.2902 & 0.4976 & Shrubs \\
\hline 4 & 0.4976 & 0.5988 & Crops \\
\hline 5 & 0.5988 & 0.6968 & Conifers \\
\hline
\end{tabular}




\begin{tabular}{l|l|l|l|}
6 & 0.6968 & 0.7846 & $\begin{array}{c}\text { Dense leaf } \\
\text { forest }\end{array}$ \\
\hline
\end{tabular}

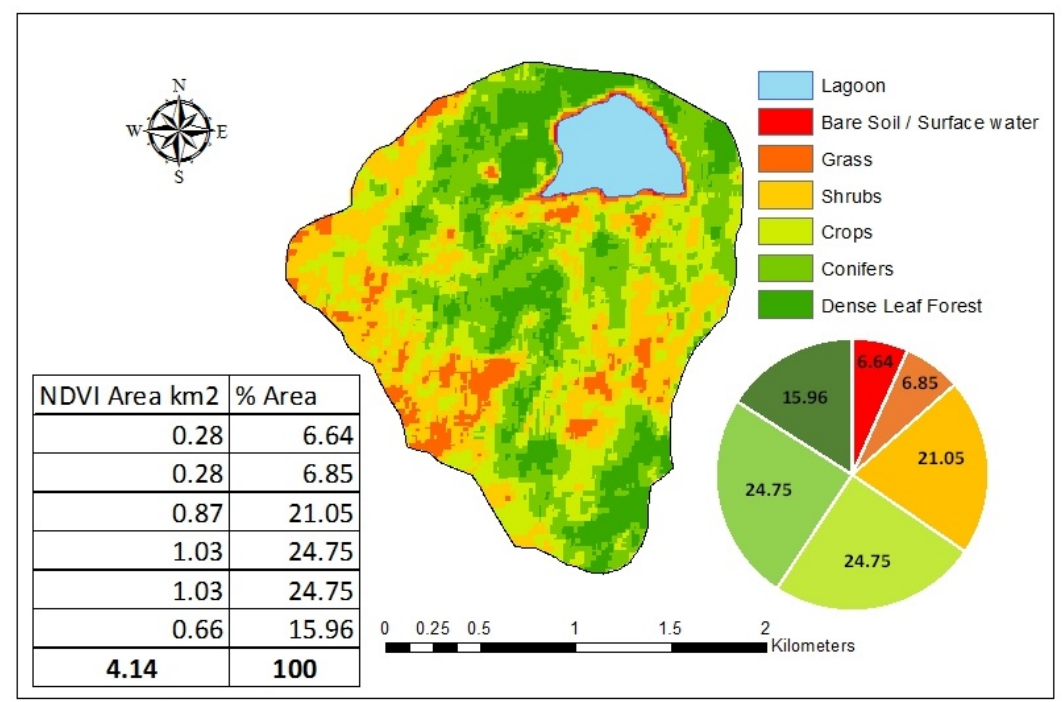

Figure 14. Normalize difference vegetation index for Calderas watershed, pie chart shows area of each characteristic enclosed in the catchment area.

The broadleaf forest at the catchment area is the most complex vegetative layer within the land cover. Under natural conditions this dense forest layer is composed of a diversity of broadleaf trees and intermediate shrubs at higher elevations on the steepest slopes of the catchment area. Natural and man-made disturbances affect this layer of land cover within the basin. Natural erosional processes can cause landslides affecting the forest extension of the area increasing risk to villagers. However, human interactions such as deforestation of forest cover is the main contributor to reduced forest cover within the catchment. The use of firewood for cooking force the villagers to obtain their fuel from nearby sources. Despite the effort of the authorities on developing conservation plans for the park, the subject of matter is that $90 \%$ of the parks area is considered private by the villagers, being the main open vent and volcanic edifice of Pacaya the only land of public domain (Lira Prera, 2005). 


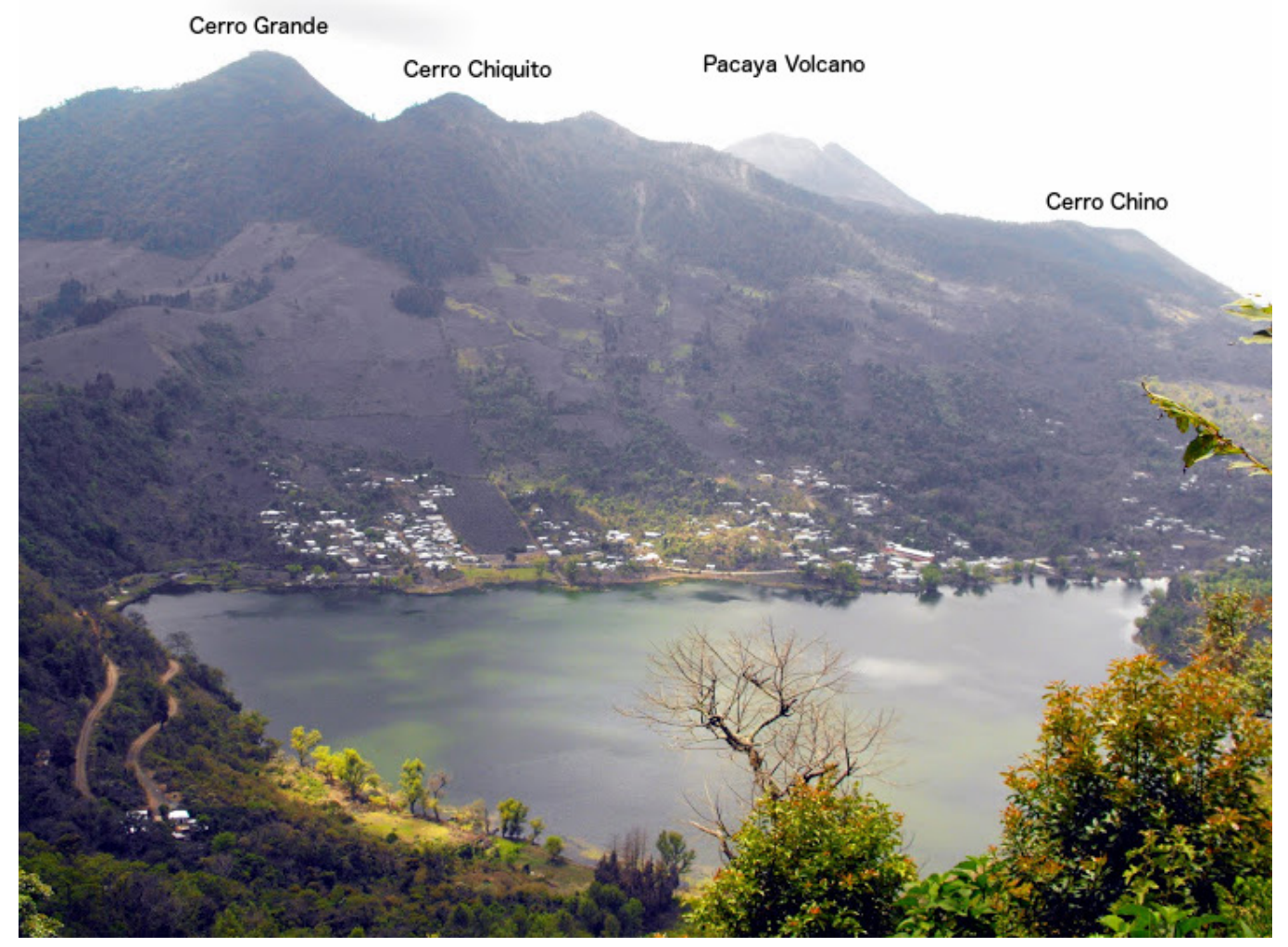

Figure 15. View of Calderas Lake and south section of the basin. Image taken from Cerro Hoja de Queso. Cerro Grande; highest peak to the left, followed by Cerro Chiquito (center) and Pacaya volcano in the back. Note the natural forest cover of protected area (photo: author).

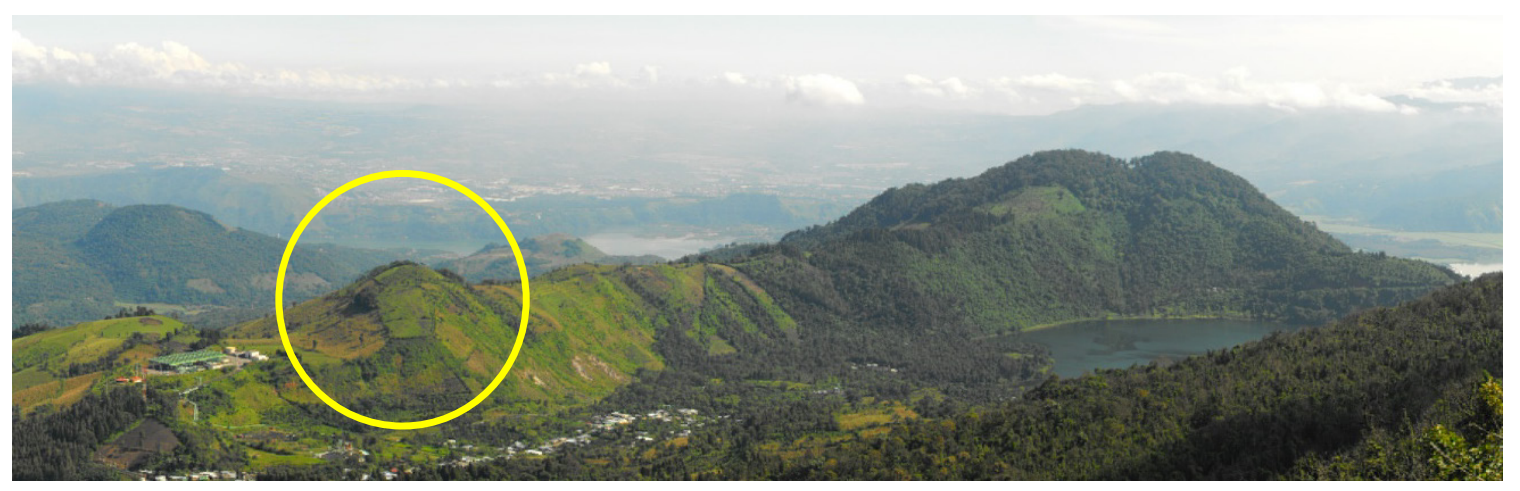

Figure 16. View of Calderas Lake from Cerro Chino. Note the natural forest cover of protected area. A potential interpreted horst fault feature to the left of the caldera, common landscape morphology from reverse faults (photo: author).

Soil field capacity and root zone depth are the only soil parameter inputs within the model. Each one is calibrated as a single item; yet, they function as a product inside the TMWB. Soil field capacity is related to the porosity and the soil-water 
relationship of a soil. Alternatively, root zone thickness refers to the average depth in which vegetative roots triggers an effective $A E T$. Soil field capacity values for Calderas catchment are based on Guatemala taxonomic soil map (Ministerio de Agricultura, 2000). Parameters for soils at the catchment area were inferred from the Water conditions in natural soils table from Dingman (2002) (Table 4) and applied on projects for spring discharge modeling (Fish, 2011; Kucharski, 2010; Shonsey, 2009). The maximum root-zone depth was estimated using values for tropical forest trees (Jackson et al., 1996). A detailed soil and vegetation study was not completed to define a specific distribution, however, maximum and minimum values for both parameters where used to determine possible ranges of net precipitation. The range values for soil field capacity were estimated from a range of values for loam soils (soils not predominantly composed of sand, silt or clay), which share similar soil porosities with volcanic soils composed of tuffs and mixtures of fine and coarse volcaniclastic material (Dingman 2002, p 225). Mean values of soil field capacity and root zone depth chosen where 0.20 and $500 \mathrm{~mm}$, respectively.

Table 3. Range values for root zone depth and field soil capacity calculates used for TMWB via Hamon equation.

\begin{tabular}{|c|c|c|}
\hline Watershed parameters & Minimum & Maximum \\
\hline Soil field capacity $\left(\theta_{f c}\right)$ & 0.15 & 0.25 \\
\hline Root zone depth $\left(\zeta_{f c}\right)$ & $250 \mathrm{~mm}$ & $1000 \mathrm{~mm}$ \\
\hline
\end{tabular}

\subsubsection{Hamon equation}

As previously stated, this method estimates actual evaporation (ET) as water is removed from the surface equalizing potential evapotranspiration ( $P E T$ ) from sufficient precipitation over the watershed. Many equations can be used to calculate $P E T$, however, this method requires less variables than other complex methods (Lu et al., 2005). Therefore, this model was selected to achieve my research objectives based on the available data. The equation derives potential evapotranspiration based on mean air temperature and is expressed as 


$$
P E T=924 \cdot D \cdot \frac{e_{a\left(T_{a}\right)}^{*}}{T_{a}+273.2}
$$

Error!

Bookmark not defined.(8)

Where:

$$
\begin{aligned}
& P E T=\text { potential evapotranspiration }(\mathrm{mm} / \text { month }) \\
& D=\text { day length }(\mathrm{hr}) \\
& e_{a}^{*}=\text { saturation vapor pressure at the mean daily temperature }(\mathrm{kPa}) \\
& T a=\text { mean daily temperature }\left({ }^{\circ} \mathrm{C}\right)
\end{aligned}
$$

Saturation vapor pressure at the mean daily temperature is estimated as (Dingman 2002):

$$
e_{a}^{*}\left(T_{a}\right)=0.611 \cdot \exp \left(\frac{17.3 T_{a}}{T_{a}+237.3}\right) \text { Error! Bookmark not defined. }
$$

\subsection{Lake evaporation}

Evaporation is a natural process occurring continuously on water reservoirs. However, evaporation volumes from lakes and other reservoirs are not simple to measure. These rates are affected by many factors including: climate, topography and physiography of the water body. Furthermore, water has the potential to transport stored heat within the reservoir itself and out of it. Henceforth, such rate is controlled by the available energy that affects how water vapor diffuses into the atmosphere. Basic models based on solar radiation and maximum air temperature can be used to estimate daily evaporation on tropical setting lakes (Abtew, 2001; Rosenberry et al., 2007). The climate data gathered for Calderas basin is sufficient enough to test and solve for lake evaporation $\left(E_{L}\right)$ as temperature-based group equations.

\subsubsection{Blaney-Criddle equation}

This method has been extensively used in the United States and elsewhere ( $\mathrm{Xu}$ \& Singh, 2001) for estimating $E_{L}$ as a temperature-based equation group. The equation is expressed as: 


$$
E_{L}=\frac{\left(0.49 T_{a}+8.13\right) D H_{m}}{T H_{y}\left(T D_{m}\right)}
$$

Where:

$$
\begin{array}{ll}
E_{L}=\text { evaporation } & T H_{y}=\text { annual daylight hours } \\
T_{a}=\text { mean monthly temperature in }{ }^{\circ} \mathrm{C} & T D_{m}=\text { total days (month) } \\
D H_{m}=\text { daylight hours per month } &
\end{array}
$$

\subsubsection{Papadakis equation}

Papadakis method is a simple empirical scheme for estimating evaporation requiring only temperature as input data. This method is based on the difference between maximum and minimum daily saturated vapor pressures over a certain number of days in a month. Studies have pointed out poor performances of the Papadakis in estimating potential evapotranspiration (Xu \& Singh, 2001). Yet, found as a reliable alternative when there is not enough climatic data (Allen et al., 1998). The estimated evaporation from the Papadakis equation can be therefore mathematically expressed as:

$$
E_{L}=0.5625\left(e_{s} \max -\left(e_{s} \min -2\right)\right)\left(\frac{10}{T D_{m}}\right) \text { Error! Bookmark not }
$$

Where:

$E_{L}=$ evaporation

$e_{s} \max$ and $e_{s} \min =$ saturated vapor pressures at daily maximum and minimum air temperatures

$T D_{m}=$ number of days in a month

\subsection{TMWB Water quality}




\subsubsection{Partial chemistry}

Collected field data included basic water quality parameters and water samples for partial chemistry. Water samples were collected from the intake pipelines water for Caldera's and other community intakes located at Laguna Calderas measured twice a month from June 2012 to December 2012. Figure 17 show the location of sampling sites. Water samples were collected in clean, $600 \mathrm{ml}$ plastic bottles and measurements were done in-situ using $\mathrm{HACH}$ water quality field kits for $\mathrm{pH}$, nitrites, nitrates, phosphates, hardness, alkalinity, chloride, ammonia, and iron (Figure 18). See table 4 for methods on partial chemistry analysis applied on samples. Field results were obtained by identifying values using color code chart on milligrams per liter $(\mathrm{mg} / \mathrm{l})$ scale for each sample. In addition to the physical properties measured at site, samples from June to September 2012 were sent to Michigan Tech's Geology Department for further laboratory analysis on water quality parameters such as total dissolved solids (TDS) and electrical conductivity (EC) for enhancing the field dataset. 


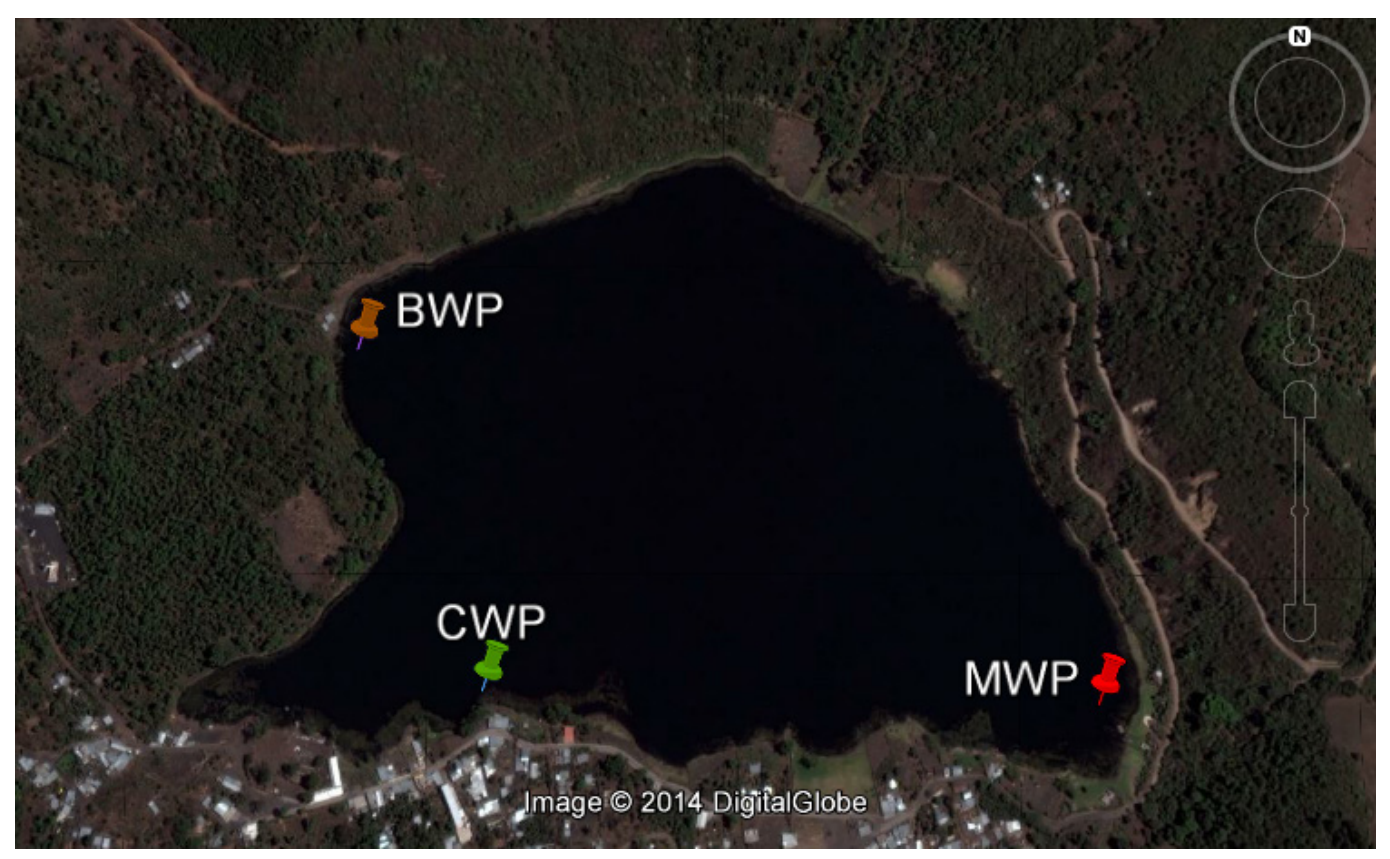

Figure 17. Sampling point locations at Laguna Calderas. CWP (Calderas) pumps water to Calderas community on a daily basis. MWP (Mesillas) and BWP (Bejucal) extract water to the other 16 communities on alternate days in a monthly basis. (Source: Google Earth)

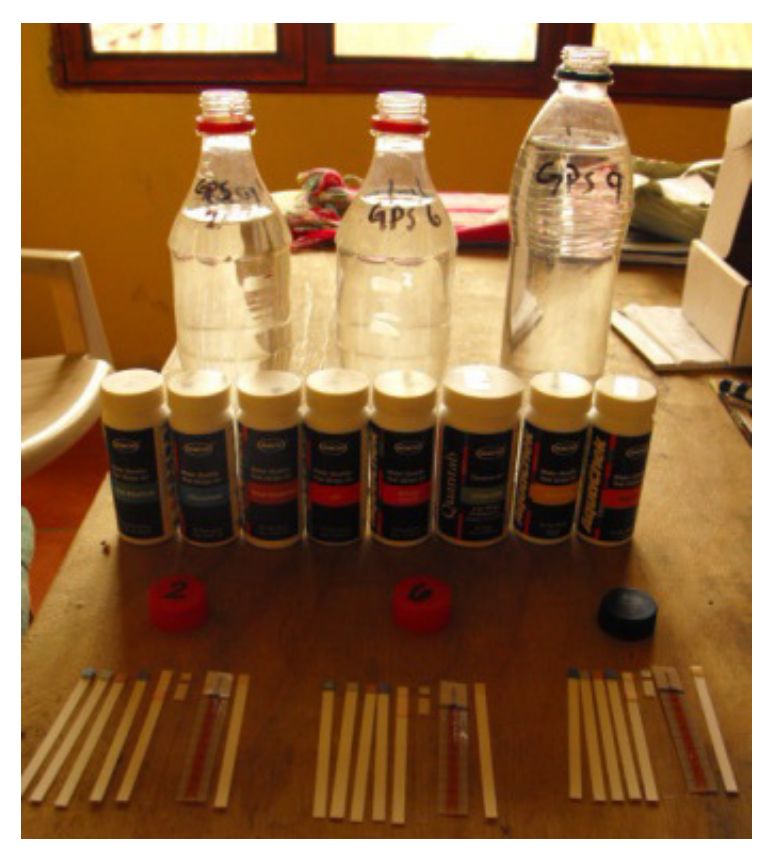

Figure 18. Test strip water sampling for partial chemistry. (photo: author)

Table 4. Summary of water quality analytical methods.

$$
-35-
$$




\begin{tabular}{|c|c|c|}
\hline Type of analysis & Method name & Detection range \\
\hline \multicolumn{3}{|l|}{ Partial chemistry } \\
\hline Nitrite & $\begin{array}{l}\text { Test strip color match } \\
10-107-04-2-b\end{array}$ & $\begin{array}{c}0-3 \mathrm{mg} / \mathrm{l} \\
* \mathrm{RL} 0.4 \mathrm{mg} / \mathrm{l}\end{array}$ \\
\hline Total iron & $\begin{array}{l}\text { Test strip color match } \\
\qquad \mathrm{Sm} 3500 \text { feb }\end{array}$ & $\begin{array}{c}0-5 \mathrm{mg} / \mathrm{l} \\
* \mathrm{RL} 0.01 \mathrm{mg} / \mathrm{l}\end{array}$ \\
\hline Copper & Bicinchoninate & $0-5 \mathrm{mg} / \mathrm{l}$ \\
\hline Ammonia & Test strip color match & $0-6 \mathrm{mg} / \mathrm{l}$ \\
\hline $\mathrm{pH}$ & Test strip color match & $4-9 \mathrm{pH}$ \\
\hline Nitrate & $\begin{array}{l}\text { Test strip color match } \\
\text { Cadmium reduction } \\
10-107-04-2-b\end{array}$ & $\begin{array}{c}0-50 \mathrm{mg} / \mathrm{l} \\
0-3 \mathrm{mg} / \mathrm{l} \\
*_{\mathrm{RL}} 0.4 \mathrm{mg} / \mathrm{l}\end{array}$ \\
\hline Phosphate & $\begin{array}{c}\text { Test strip color match } \\
\text { EPA } 365.1\end{array}$ & $\begin{array}{c}0-50 \mathrm{mg} / \mathrm{l} \\
*_{\mathrm{RL}} 0.1 \mathrm{mg} / \mathrm{l}\end{array}$ \\
\hline Sulfate & Sm 4500 so4e & $* \mathrm{RL} 10 \mathrm{mg} / \mathrm{l}$ \\
\hline Total alkalinity & $\begin{array}{c}\text { Test strip color match } \\
\text { Titration / sulfuric acid } \\
\text { EPA } 310.2\end{array}$ & $\begin{array}{c}0-240 \mathrm{mg} / \mathrm{l} \\
20-400 \mathrm{mg} / \mathrm{l} \\
* \mathrm{RL} 0-20 \mathrm{mg} / \mathrm{l}\end{array}$ \\
\hline Total hardness & $\begin{array}{c}\text { Test strip color match } \\
\text { EDTA } \\
\text { Sm } 2340 \mathrm{c}\end{array}$ & $\begin{array}{c}0-425 \mathrm{mg} / \mathrm{l} \\
1-30 \mathrm{gpg} \text { powder pillows } \\
*_{\mathrm{RL}} 20 \mathrm{mg} / \mathrm{l}\end{array}$ \\
\hline Chloride & Test strip color match & $30-600 \mathrm{mg} / \mathrm{l}$ \\
\hline Sodium & Sm 3500 nab & *RL $5 \mathrm{mg} / \mathrm{l}$ \\
\hline Fluoride & $\begin{array}{l}\text { Test strip color match } \\
\qquad \mathrm{Sm} 4500 \mathrm{fc}\end{array}$ & $\begin{array}{l}0-2.0 \mathrm{mg} / \mathrm{l} \\
* \mathrm{RL} 0.1 \mathrm{mg} / \mathrm{l}\end{array}$ \\
\hline Conductivity & $\begin{array}{c}\mathrm{HACH} 8160 \text { direct measurement } \\
\text { EPA } 120.1\end{array}$ & $\begin{array}{c}0.2-200,000 \mu \mathrm{s} / \mathrm{cm} \\
* \mathrm{RL} 1 \mu \mathrm{s} / \mathrm{cm}\end{array}$ \\
\hline
\end{tabular}

${ }^{*} \mathrm{RL}=$ reporting limit (Michigan Department of Environmental Quality water testing laboratory)

\subsubsection{Microbiological indicators}

The presence of total coliforms and $E$. coli bacteria are worldwide indicators of fecal contamination (UNICEF, 2012). Special attention to human health is taken when 
these pathogens are present in drinking and domestic waters. These organisms are known to be the primary cause of diarrhea, colitis and other waterborne illnesses affecting people exposed to contaminated water. Standard methods such as membrane filtration, multiple tube fermentation, most probable number, and fluorogenic and chromogenic media methods are used for identifying total coliforms and E. coli (Illman, 2006).

Field constraints made the application of such methods for microbial testing impractical at site. For this reason, the $3 \mathrm{M}$ Petrifilm ${ }^{\mathrm{TM}}$ was used for microbial testing. The ease of transport, low-cost equipment-less nature and simplicity of the method were key factors for performing this method in the field. This method proved to be effective on the overall quantification and characterization of microbial content for domestic water consumption in rural villages of developed countries, where standard procedures are often difficult to perform (Eckner, 1998; Manafi, 1996; Seib, 2011).

This method was initially developed as a low-cost food security screening. However, is considered to be effective and equivalent to other commercial chromogenic methods for drinking water such as Colilert 18 and Readycult (Mattelet, 2006; Seib, 2011). No other equipment is needed to estimate total coliform and $E$. coli counts with this method. Direct counting of total coliform and $E$. coli is the primary method for obtaining results and is made after the following sampling procedure:

1) A 1-ml water sample is spread on a plate culture medium.

2) Samples then hold an incubation period of 24 hours at $35^{\circ} \mathrm{C}$. Time and temperature is important for bacterial growth.

3) Red and blue dots appear after incubation period indicating colony-forming units (CFUs) of total coliform and E. coli were direct counting is then performed (Figure 19).

Sample incubation was neither possible using standard equipment nor feasible at site location. Trial and error for the incubation process provided a rudimentary alternate method for colony and bacterial incubation. Plate samples were covered with a thin cardboard and placed next to the skin (worked best to place them between the ankles and socks) for the 24-hour period required from $3 \mathrm{~m}^{\mathrm{TM}}$ procedure instructions. Since, body temperature oscillates from $35-37^{\circ} \mathrm{C}$, the alternate method aid samples to incubate bacteria for further analysis. 
According to $3 \mathrm{M}$ Petrifilm ${ }^{\mathrm{TM}}$, the counting plate threshold is to be $150 \mathrm{CFUs}$. If any sample exceeds counts over 150 then are considered "too numerous to count" (TNTC). A secondary method is then applied to estimate microbial counts. The counted value is averaged among the grids and multiplied by 20 , which refers to the circular growth area $\left(20 \mathrm{~cm}^{2}\right)$ of the plate medium to obtain CFU estimation values for each sample.

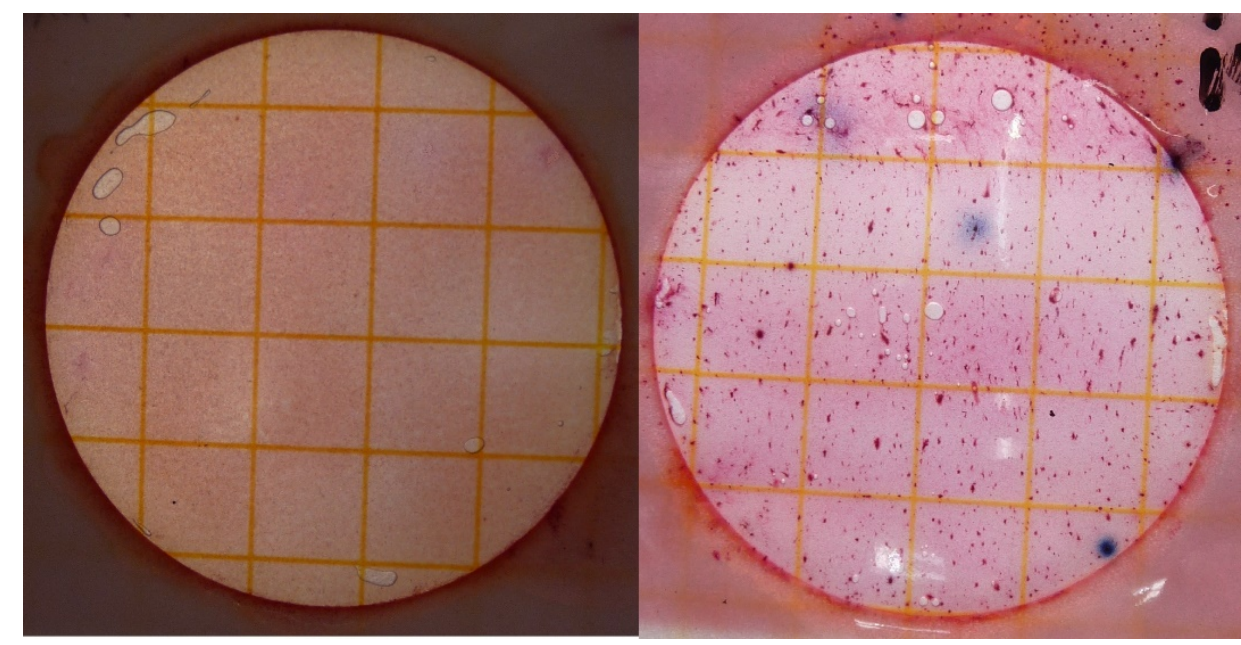

Figure 19. $3 \mathrm{~m}$ Petrifilm ${ }^{\mathrm{TM}}$ counting plates, no bacterial contamination (left) and total coliform and E. coli contamination (right). (photo: author)

Obtained results are to be considered as microbial content approximates, because incubation period was not always done at $35^{\circ} \mathrm{C}$ as required by $3 \mathrm{M}$ Petrifilm ${ }^{\mathrm{TM}}$ methodologies. In addition, sample dilution method for reducing counts to $150 \mathrm{CFUs}$ could not be applied due to the lack of sterile water to perform such procedure. This method served as an approach to characterize the bacterial content of water prior to withdrawal and storage for distribution at Calderas community tank. This method is considered to be a visual representation of bacterial contaminants within the water supply and not as definite values for microbial contamination at Calderas Lake. 


\section{Results}

Two main results were derived from this study; 1 ) a water budget for Calderas basin, and, 2) basin-lake groundwater seepage and chemical interaction in relation to its overall quality of the lake. All of the climatic parameters used in the water balance are in Appendix A. Volumes of watershed evapotranspiration and lake evaporation arising from collected data are computed and comparisons between suggested methods are made. An estimated water budget reflects water availability and storage within Calderas micro basin as climatic conditions take effect on the area. Impacts on water chemistry arising from regional geology, anthropogenic activities resulting from percolation and surface drainage are made to assess the communities' lake intakes. The distribution of physicochemical parameters for Calderas Lake are in Appendix B. These are described as low concentration variation over time of sampling. Sources of contamination are speculated to affect the overall quality of the lake over time. However, the interconnection between groundwater and surface water in relation to geological characteristics of the area is to be analyzed in an effort to understand pollutant concentrations and pathways. The effects of water pollution are based on anthropogenic observations interpreted as environmentally reluctant practices amongst villagers. None of the studied parameters exceed neither local nor international drinking water guidelines. Finally, the biological analyses are included in attempt to understand the impact from septic percolation in an effort to promote better environmental practices from villagers.

\subsection{Lake evaporation}

A comparison between mean monthly values of lake evaporation from the selected methods are shown on Table 5. In the absence of direct measurements of evaporation, the Hamon equation was used as a criterion to evaluate the performance of the other methods. A visual inspection (Figure 20) show underestimation of lake evaporation with respect to the Hamon method. 


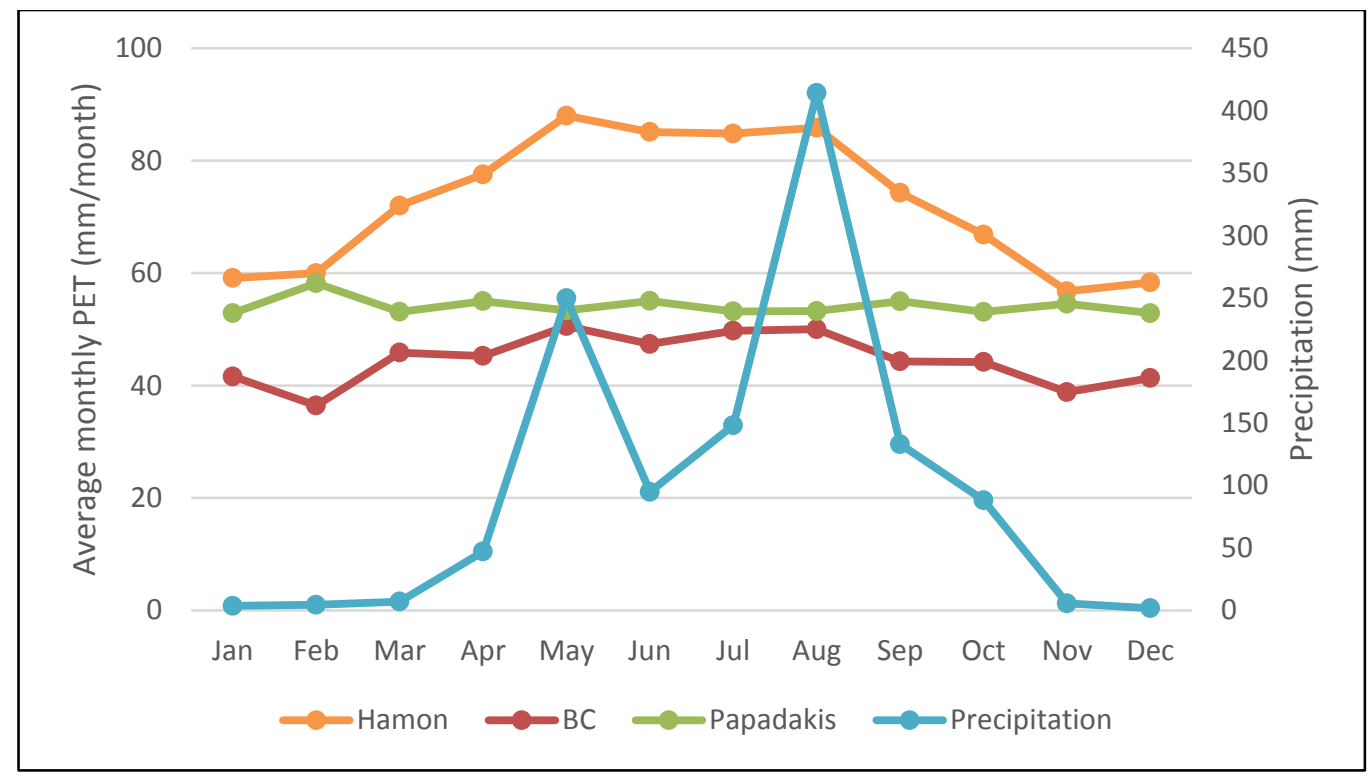

Figure 20. Comparison of computed et using different methods.

The performance of each method was made through the computation of the root mean squared error ( $\mathrm{RMSE}^{7}$ ) between the mean monthly evaporation computed through Hamon, Blaney-Criddle and Papadakis methods (Table 5). Figure 21 show linear regression analysis after the RMSE analysis to establish the relationship between the $E_{L}$ values from each method. TMWBA good performance for the Blaney-Criddle method is observed. This method estimated an RMSE of $1.63 \mathrm{~mm} / \mathrm{month}$ and 0.85 for residual coefficients $\left(R^{2}\right)$. These values are slightly below Hamon showing a positive relation between estimated values. These can be interpreted as good fit and performance of the method for estimating $E_{L}$ at Calderas Lake. Papadakis method show the worst performing method with and RMSE of $1.47 \mathrm{~mm} / \mathrm{month}$ and a squared residual coefficient $\left(R^{2}\right)$ of 0.03 . A downtrend is observed when estimating $E_{L}$ for 20092015 Calderas Lake study period.

7 RMSE $=\sqrt{\frac{1}{12} \sum_{i=1}^{12}\left(E T_{i, \text { method }}-E T_{\text {Hamon }}\right)^{2}}$ 


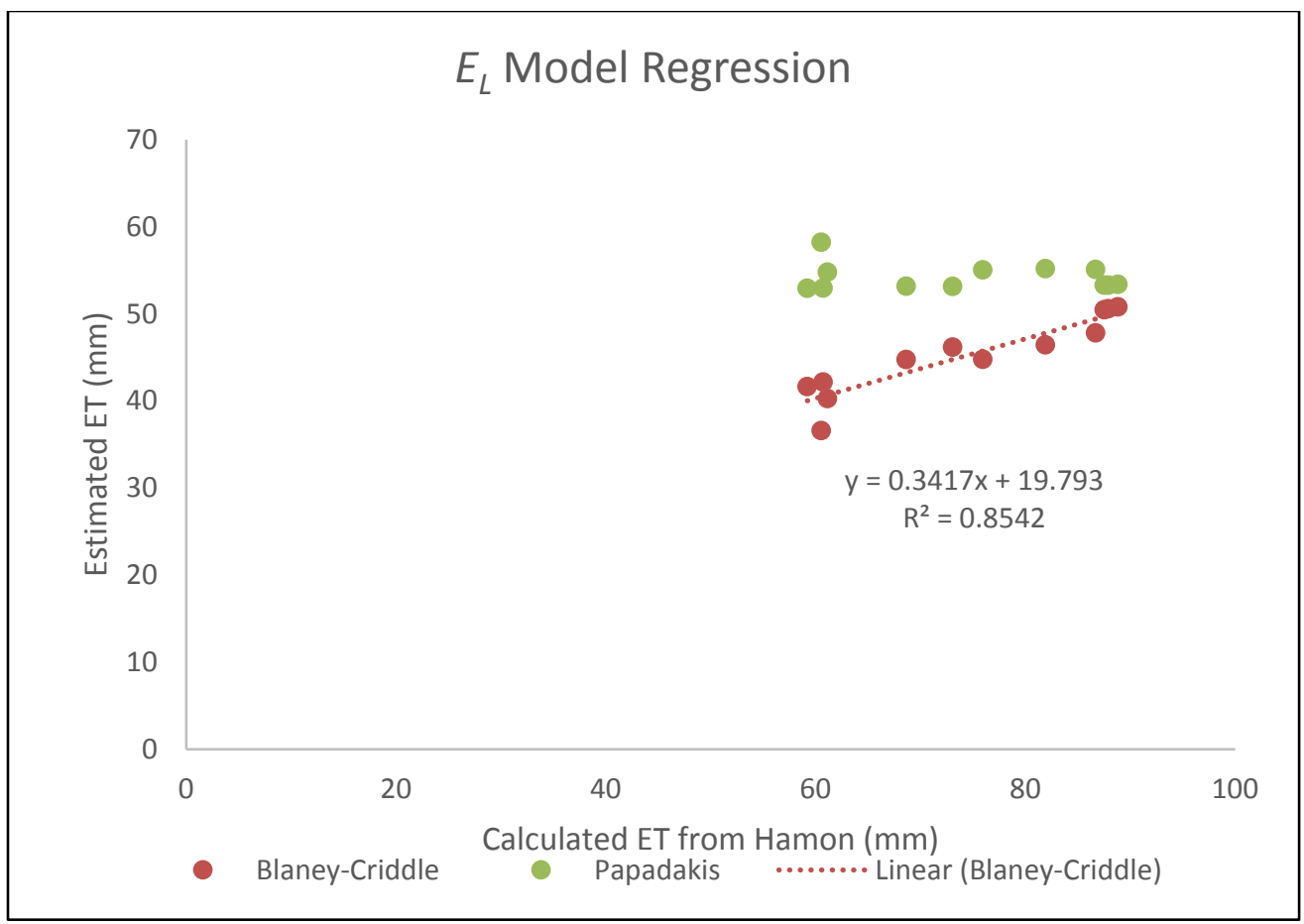

Figure 21. Uptrend linear correlation (red line) between $E_{L}$ calculations from Hamon and estimations from Blaney-Criddle.

Table 5. Comparison of mean monthly computed $E_{L}$ values for 2009-2015 period.

\begin{tabular}{cccc}
\hline Month & $\begin{array}{c}\text { Hamon } \\
\mathbf{( m m )}\end{array}$ & $\begin{array}{c}\text { Blaney- } \\
\text { Criddle } \\
\mathbf{( m m )}\end{array}$ & $\begin{array}{c}\text { Papadakis } \\
\mathbf{( m m})\end{array}$ \\
\hline Jan & 60.7 & 42.2 & 53.0 \\
Feb & 60.6 & 36.6 & 58.2 \\
Mar & 73.1 & 46.2 & 53.2 \\
Apr & 81.9 & 46.4 & 55.2 \\
May & 88.8 & 50.8 & 53.4 \\
Jun & 86.7 & 47.8 & 55.1 \\
Jul & 87.9 & 50.6 & 53.3 \\
Aug & 87.5 & 50.5 & 53.3 \\
Sep & 76.0 & 44.8 & 55.1 \\
Oct & 68.6 & 44.7 & 53.2 \\
Nov & 61.1 & 40.3 & 54.8 \\
Dec & 59.2 & 41.6 & 52.9 \\
\hline Mean & 74.4 & 45.2 & 54.2 \\
RMSE & -- & 1.63 & 1.47 \\
R2 & -- & 0.85 & 0.03 \\
\hline & & $-41-$ &
\end{tabular}


Table 6 show mean annual evaporation values in $\mathrm{mm}$ calculated using different methods over Calderas 2009-2015 period. It can be observed that Blaney-Criddle and Papadakis underestimate Hamon computations by $6 \%$ and $7 \%$, respectively. The differences from $E_{L}$ values for these two equations indicate little seasonal bias, revealing no significant output from the system. Despite the differences between estimations, both methods reflect a small volume referred as output from precipitated water over the lake area resulting in cloud forming over the basin. This phenomenon keeps humidity conditions favorable for water storage in soils over the basin.

Table 6. Comparison of average annual $E_{L}$ computed between methods for 2009-2015 period

\begin{tabular}{lcccc}
\hline $\begin{array}{c}\text { Calculation } \\
\text { method }\end{array}$ & $\begin{array}{c}\text { Annual } \\
\text { average } \\
(\mathbf{m m})\end{array}$ & $\begin{array}{c}\text { Maximum } \\
\mathbf{( \mathbf { m m } )}\end{array}$ & $\begin{array}{c}\text { Minimum } \\
\mathbf{( \mathbf { m m } )}\end{array}$ & $\begin{array}{c}\text { Difference } \\
\mathbf{( \% )}\end{array}$ \\
\hline Hamon & 892.2 & 909.3 & 868.5 & - \\
$\begin{array}{l}\text { Blaney- } \\
\text { Criddle }\end{array}$ & 542.4 & 547.7 & 535.5 & 6 \\
Papadakis & 650.5 & 651.2 & 649.6 & 7 \\
\hline
\end{tabular}

\subsection{Water budget}

Figure 22 depicts the water budget components from the TMWB for Calderas micro-basin. The Hamon equation for estimating ET is embedded into the TMWB model, and therefore is used as baseline equation for determining $E T$. Evapotranspiration occurs as a fraction of precipitation within the watershed, thereby soil moisture and recharge into Calderas Lake take account after ET is subtracted from precipitation. It is important to note that the recharge curve mimics precipitation curve which falls into the watershed, therefore merging with the net precipitation curve after applying the model. During the rainy season, soils hold moisture. Excess soil moisture beyond the moisture-holding capacity of the soil is assumed to infiltrate further, recharging the shallow aquifer, and migrating downslope discharging into the lake. 


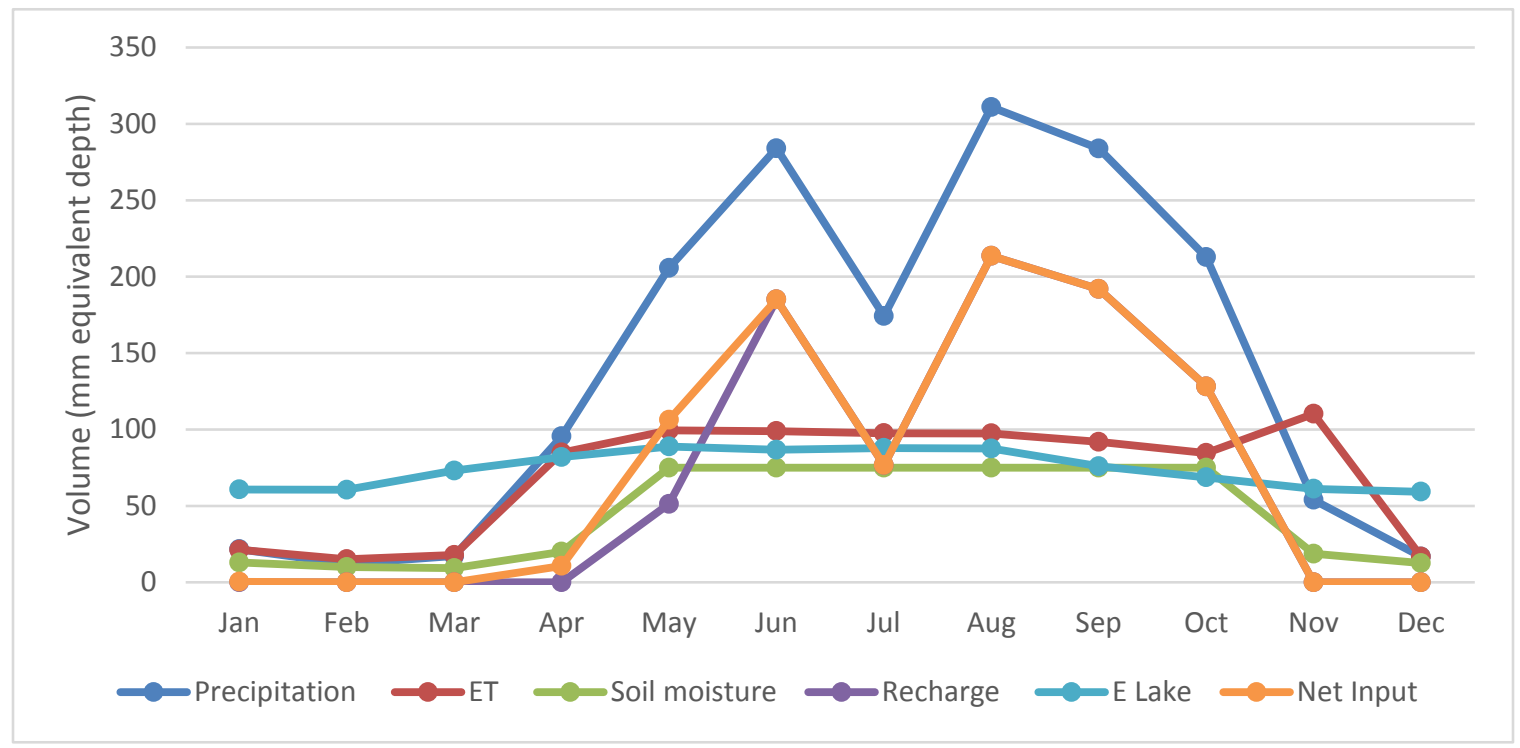

Figure 22. Thornthwaite type water balance for Calderas watershed for 2009-2015 period.

Table 7 shows volumes $\left(\mathrm{m}^{3}\right)$ and percentages (\%) - upper and lower halves, respectively - of the water budget components after TMWB analysis. This aids in visualizing recharge as net precipitation over the basin. The established water budget components in this analysis are:

1. Watershed precipitation input $=$ the sum of mean monthly precipitation for our study period $x$ area of watershed (basin - lake)

2. Seepage from recharge into lake $=$ calculated recharge $(\mathrm{m})$ after $P E T x$ lake area $\left(\mathrm{m}^{2}\right)$

3. Direct precipitation $=$ total rainfall $(\mathrm{m}) \times$ lake area $\left(\mathrm{m}^{2}\right)$

4. $E T$ from watershed = estimated $E T$ values $(\mathrm{m})$ from different methods $x$ watershed area $\left(\mathrm{m}^{2}\right)$

5. Lake evaporation $=E_{L}$ values $(\mathrm{m}) \times$ lake area $\left(\mathrm{m}^{2}\right)$

6. Community withdrawals $=$ community tank volume $x$ \#pumping times/day $x 26$ days/month (no pumping on Sundays) $x$ benefited population (from section $\mathbf{2 . 3}$ )

7. Net precipitation $=$ inputs $(1,2,3)$ - outputs $(4,5,6)$

Volumes in $\mathrm{m}^{3}$ are then converted in percentages to establish a simpler mathematical relation between the inputs and outputs of Calderas watershed. 
As observed in Figure 22, $E_{L}$ values affect the amount of available water for recharge as net precipitation in the watershed. Considering net precipitation as the sum of all the inputs minus outputs within our analysis, we obtained volumes $\left(\mathrm{m}^{3}\right)$ latter translated into percentages of water availability. TMWBE $L$ estimates vary as little as $10 \%$ to $11 \%$ for the selected methods.

After ELTMWB evaluation for Blaney-Criddle and Papadakis methods, results show net precipitation as water availability of $11 \%$ respectively. These methods portray constant evaporation through the wet and dry season, most of the available water remains within $1 / 4$ of the total input as precipitation - not accounting for the amount of groundwater that interacts with the system- within the watershed.

Table 7. Water budget components for Calderas basin for 2009-2015 period.

\begin{tabular}{|c|c|c|c|c|}
\hline $\begin{array}{l}\text { Water budget } \\
\text { component }\end{array}$ & $\begin{array}{l}\text { TMWB } \\
\text { (m3) }\end{array}$ & Hamon (m3) & $\begin{array}{c}\text { Blaney-Criddle } \\
\text { (m3) }\end{array}$ & $\begin{array}{l}\text { Papadakis } \\
\text { (m3) }\end{array}$ \\
\hline $\begin{array}{c}\text { Watershed } \\
\text { Precipitation Input }\end{array}$ & \multicolumn{4}{|c|}{$6,501,442$} \\
\hline $\begin{array}{c}\text { Direct } \\
\text { Precipitation onto } \\
\text { Lake }\end{array}$ & \multicolumn{4}{|c|}{422,172} \\
\hline $\begin{array}{l}\text { Evapotranspiration } \\
\text { from Watershed }\end{array}$ & \multicolumn{4}{|c|}{$(3,218,081)$} \\
\hline Lake Evaporation & & $(223,052)$ & $(135,602)$ & $(162,626)$ \\
\hline $\begin{array}{l}\text { Community } \\
\text { Withdrawals }\end{array}$ & \multicolumn{4}{|c|}{$(2,824,615)$} \\
\hline Net Input & 880,917 & 657,865 & 745,315 & 718,291 \\
\hline $\begin{array}{l}\text { Water budget } \\
\text { component }\end{array}$ & TMWB & Hamon & Blaney-Criddle & Papadakis \\
\hline $\begin{array}{l}\text { Seepage from } \\
\text { recharge into lake }\end{array}$ & \multicolumn{4}{|c|}{$47 \%$} \\
\hline $\begin{array}{c}\text { Direct } \\
\text { Precipitation onto } \\
\text { Lake }\end{array}$ & \multicolumn{4}{|c|}{$6 \%$} \\
\hline $\begin{array}{l}\text { Evapotranspiration } \\
\text { from Watershed }\end{array}$ & \multicolumn{4}{|c|}{$-49 \%$} \\
\hline
\end{tabular}




\begin{tabular}{|c|c|c|c|c|}
\hline Lake Evaporation & $0 \%$ & $-3 \%$ & $-2 \%$ & $-3 \%$ \\
\hline $\begin{array}{c}\text { Community } \\
\text { Withdrawals }\end{array}$ & \multicolumn{5}{|c|}{$\mathbf{- 4 1 \%}$} \\
\hline Net Input & $14 \%$ & $10 \%$ & $11 \%$ & $11 \%$ \\
\hline
\end{tabular}

Lastly, Hamon as our baseline method performance show a $10 \%$ available water as net input for Calderas watershed. When adding percentages from evapotranspiration and lake evaporation the total net precipitation for the watershed ascends up to $25 \%$ of available water for replenishing and recharging the system.

\subsection{Calderas Lake partial chemistry}

Twenty-seven water samples have been taken from Calderas Lake intakes from June through December 2012 (Table 8). Nine from the eastern shore, nine from the south-central and eight from the northern shore of Calderas lake where the intakes are located. Twenty samples from older studies (AMSA, unpublished data 2007-2008) were included in the database of Calderas Lake partial chemistry for comparative purposes. These older samples were collected from different points and at different depths within the lake between 2007 and 2008. A post-field analysis subset was sent to Michigan's Department of Environmental Quality (MDEQ) for comparison between datasets.

Analyte concentrations of field, post-field analysis and previously analyzed water samples are reported in Tables 8,9 and $10 \mathrm{in} \mathrm{mg} / \mathrm{l}$, with a measurement confidence level of $95 \%$. Not all chemical analytes were detected from field sampled measurements. No sodium, nitrate, iron or fluoride has been detected above the detection limit of $5 \mathrm{mg} / \mathrm{l}, 0.4 \mathrm{mg} / \mathrm{l}, 0.01 \mathrm{mg} / \mathrm{l}$, or $0.1 \mathrm{mg} / \mathrm{l}$, respectively. Sampled chemistry reveal concentrations of alkalinity, hardness, $\mathrm{pH}$, nitrate, ammonia and chloride (maxima of 240, 425, 9, 1, 0.5, and $21 \mathrm{mg} / \mathrm{l}$, respectively). Figure 23 shows concentration diagrams for related analytes between sampled datasets. 

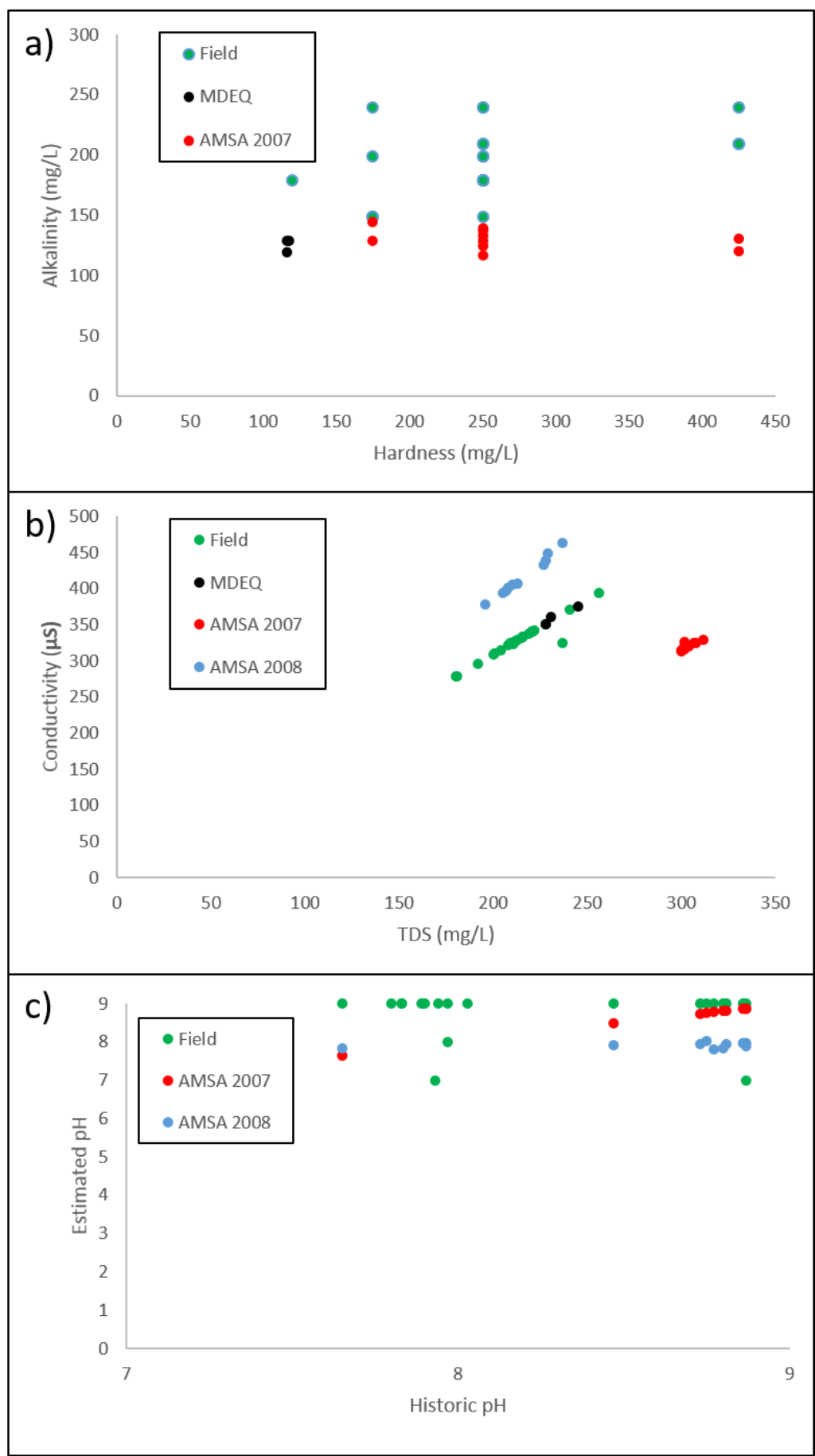

Figure 23. a) Hardness and Alkalinity diagrams for field measurements (green), MDEQ sample subset (black) and historical data from AMSA, 2007(red); b) TDS and Conductivity diagrams for field measurements (green), MDEQ sample subset (black) and AMSA's 2007 (red) and 2008 (blue) historical data; c) pH diagram comparison between AMSA historical data for 2007 (red) and 2008 (blue). 
Higher concentrations of alkalinity and hardness were found on field samples in comparison to previous studies and post-field analysis (Figure 23a). Although alkalinehard water does not affect the overall health of any human consumer, it is considered as a natural neutralizer to our bodies adding minerals that our bodies may lack (WHO, 2011). Elevated hardness can cause precipitation of detergents, making them less effective. Both can contribute to scale accumulation in pipes. The relationship between TDS and conductivity for our field samples lie between previous studies concentrations (Figure 23b). Field pH measurements were slightly higher compared with previously reported measurements (Figure 23c). 
Table 8. Chemical composition in ( $\mathrm{mg} / \mathrm{I})$ of sampled water tests in Calderas Lake from June - December 2012.

\begin{tabular}{|c|c|c|c|c|c|c|c|c|c|c|c|c|}
\hline Sample & Alkalinity & $\mathbf{p H}$ & Hardness & $\mathrm{No}_{2}{ }^{-}$ & $\mathrm{No}_{3}{ }^{-}$ & $\mathrm{Po}_{4}{ }^{-3}$ & $\mathbf{N h}_{3}$ & Chloride & $\begin{array}{l}\mathrm{NaCl} \\
(\%)\end{array}$ & $\mathrm{Fe}^{+2}$ & TDS & $\begin{array}{c}\text { Conductivity } \\
(\mu s)\end{array}$ \\
\hline MWP1 & 210 & 9 & 250 & - & 1 & 5 & 0.5 & 14 & 0.003 & - & 221 & 340 \\
\hline MWP2 & 210 & 9 & 250 & - & 1 & 5 & 0.5 & 14 & 0.003 & - & 222 & 342 \\
\hline MWP3 & 180 & 7 & 250 & - & 0 & 5 & 0 & 14 & 0.003 & - & 200 & 309 \\
\hline MWP4 & 240 & 9 & 425 & - & 0 & 15 & 0.25 & 14 & 0.003 & - & 181 & 279 \\
\hline MWP5 & 150 & 9 & 250 & - & 0 & 3 & 0 & 14 & 0.003 & - & 215 & 332 \\
\hline MWP6 & 150 & 9 & 175 & - & 0 & 5 & 0 & 7 & 0.002 & - & 228 & 351 \\
\hline MWP7 & 200 & 9 & 175 & - & 0.25 & 10 & 0.25 & 14 & 0.003 & - & 209 & 324 \\
\hline MWP8 & 200 & 9 & 250 & - & 0.25 & 5 & 0.25 & 14 & 0.003 & - & 211 & 323 \\
\hline MWP9 & 180 & 9 & 250 & - & 0 & 5 & 0 & 14 & 0.003 & - & 237 & 325 \\
\hline CWP1 & 210 & 9 & 425 & - & 0 & 5 & 0 & 14 & 0.003 & - & 228 & 351 \\
\hline CWP2 & 210 & 9 & 425 & - & 0 & 5 & 0 & 14 & 0.003 & - & 221 & 341 \\
\hline CWP3 & 180 & 7 & 250 & - & 0 & 5 & 0 & 14 & 0.003 & - & 221 & 341 \\
\hline CWP4 & 200 & 9 & 250 & - & 0 & 5 & 0.25 & 14 & 0.003 & - & 213 & 329 \\
\hline CWP5 & 180 & 9 & 250 & - & 0 & 3 & 0 & 14 & 0.003 & - & 180 & 278 \\
\hline CWP6 & 180 & 9 & 250 & - & 0.25 & 5 & 0.25 & 7 & 0.002 & - & 212 & 327 \\
\hline CWP7 & 150 & 9 & 175 & - & 0 & 5 & 0 & 14 & 0.003 & - & 216 & 333 \\
\hline CWP8 & 180 & 8 & 250 & - & 0.25 & 5 & 0 & 14 & 0.003 & - & 256 & 394 \\
\hline CWP9 & 180 & 9 & 250 & - & 0 & 5 & 0.25 & 14 & 0.003 & - & 221 & 341 \\
\hline BWP1 & 240 & 9 & 250 & - & 0 & 5 & 0 & 21 & 0.004 & - & 201 & 310 \\
\hline BWP2 & 240 & 9 & 250 & - & 0 & 5 & 0 & 21 & 0.003 & - & 192 & 296 \\
\hline BWP3 & 180 & 8 & 120 & - & 0 & 5 & 0 & 14 & 0.003 & - & 204 & 315 \\
\hline BWP4 & 180 & 8 & 250 & - & 0 & 5 & 0.5 & 14 & 0.003 & - & 219 & 338 \\
\hline BWP5 & 150 & 6 & 175 & - & 0 & 2 & 0 & 14 & 0.003 & - & 216 & 333 \\
\hline BWP6 & 180 & 9 & 250 & - & 0 & 5 & 0 & 7 & 0.002 & - & 210 & 324 \\
\hline BWP7 & 240 & 7 & 175 & - & 0 & 5 & 0 & 14 & 0.003 & - & 208 & 321 \\
\hline BWP8 & 180 & 9 & 250 & - & 0 & 5 & 0 & 14 & 0.003 & - & 241 & 371 \\
\hline
\end{tabular}


Table 9. Major and minor concentrations (in $\mathrm{mg} / \mathrm{I}$ ) of Calderas Lake water chemistry sampled prior to 2012.

\begin{tabular}{|c|c|c|c|c|c|c|c|c|c|}
\hline Sample & $\begin{array}{c}\mathrm{T} \\
\left({ }^{\circ} \mathrm{C}\right)\end{array}$ & $\begin{array}{c}\text { Alkalinity } \\
\text { (mg/I) }\end{array}$ & $\mathbf{p H}$ & $\begin{array}{c}\text { Hardness } \\
(\mathrm{mg} / \mathrm{I})\end{array}$ & $\begin{array}{c}\mathrm{No}_{2}^{-} \\
(\mathrm{mg} / \mathrm{I})\end{array}$ & $\begin{array}{c}\mathrm{Nh}_{4}{ }^{+} \\
(\mathrm{mg} / \mathrm{I})\end{array}$ & $\mathrm{Po}_{4}^{-3}(\mathrm{mg} / \mathrm{I})$ & $\begin{array}{c}\text { Conductivity } \\
(\mu s)\end{array}$ & TDS $(\mathrm{mg} / \mathrm{I})$ \\
\hline $304 *$ & - & - & 8.75 & 138 & 0.01 & - & - & 324 & 308 \\
\hline $305 *$ & - & - & 8.73 & 125 & 0.02 & - & - & 324 & 307 \\
\hline $306 *$ & - & - & 8.87 & 140 & 0.02 & - & - & 318 & 301 \\
\hline $307 *$ & - & - & 7.65 & 131 & 0.01 & - & - & 329 & 312 \\
\hline $308 *$ & - & - & 8.81 & 130 & 0.02 & - & - & 316 & 302 \\
\hline $309 *$ & - & - & 8.47 & 145 & 0.01 & - & - & 326 & 302 \\
\hline $310 *$ & - & - & 8.86 & 130 & 0.01 & - & - & 314 & 300 \\
\hline $311 *$ & - & - & 8.77 & 134 & 0.02 & - & - & 320 & 304 \\
\hline $312 *$ & - & - & 8.87 & 118 & 0.01 & - & - & 313 & 300 \\
\hline $313 *$ & - & - & 8.8 & 121 & 0.01 & - & - & 320 & 304 \\
\hline Calderas pt. $1 * *$ & 19.1 & - & 8.03 & - & 0.02 & $<0.05$ & $<0.01$ & 407 & 213 \\
\hline Calderas pt. $1 \mathrm{~d} 4 \mathrm{~m} * *$ & 18.9 & - & 7.93 & - & 0.02 & $<0.05$ & $<0.01$ & 405 & 210 \\
\hline Calderas pt. 2 center** & 18.9 & - & 7.89 & - & 0.02 & $<0.05$ & $<0.01$ & 463 & 237 \\
\hline Calderas pt. 2 d $10 \mathrm{~m} * *$ & 18.7 & - & 7.83 & - & 0.02 & $<0.05$ & $<0.01$ & 378 & 196 \\
\hline Calderas pt. $3 * *$ & 19 & - & 7.94 & - & 0.02 & $<0.05$ & $<0.01$ & 433 & 227 \\
\hline Calderas pt. 3 d $4 \mathrm{~m} * *$ & 19 & - & 7.9 & - & 0.02 & $<0.05$ & $<0.01$ & 397 & 207 \\
\hline Calderas pt. $4 * *$ & 19 & - & 7.97 & - & 0.02 & $<0.05$ & $<0.01$ & 438 & 228 \\
\hline Calderas pt. 4 d $4 \mathrm{~m} * *$ & 18.9 & - & 7.8 & - & 0.02 & $<0.05$ & $<0.01$ & 394 & 205 \\
\hline Calderas pt. $5 * *$ & 19 & - & 7.97 & - & 0.02 & $<0.05$ & $<0.01$ & 448 & 229 \\
\hline Calderas pt. 5 d $4 \mathrm{~m} * *$ & 18.7 & - & 7.83 & - & 0.02 & $<0.05$ & $<0.01$ & 401 & 208 \\
\hline
\end{tabular}

*Samples from (AMSA, 2007), ** samples from (AMSA. 2008)

Table 10. Partial chemistry concentrations (in $\mathrm{mg} / \mathrm{I}$ ) of post-field water sampled tests.

\begin{tabular}{ccccccc}
\hline Sample & $\begin{array}{c}\text { Chloride } \\
(\mathbf{m g} / \mathbf{l})\end{array}$ & $\begin{array}{c}\mathbf{F}^{-} \\
(\mathbf{m g} / \mathbf{l})\end{array}$ & $\begin{array}{c}\text { Hardness } \\
(\mathbf{m g} / \mathbf{l})\end{array}$ & $\mathbf{N a}$ & $\begin{array}{c}\text { Alkalinity } \\
(\mathbf{m g} / \mathbf{l})\end{array}$ & $\begin{array}{c}\text { Conductivity } \\
(\boldsymbol{\mu s})\end{array}$ \\
\hline Lf20144* & 20 & 0.6 & 118 & 18 & 130 & 375 \\
Lf20145* & 19 & 0.5 & 116 & 17 & 120 & 351 \\
Lf20146* & 19 & 0.5 & 116 & 18 & 130 & 361 \\
\hline
\end{tabular}

*Samples sent to Michigan Department of Environmental Quality (MDEQ) 


\subsection{Microbiological content}

Rapid detection and identification of microorganisms is extremely important when assessing water quality for human consumption. Escherichia coli is used worldwide as indicator organisms for fecal contamination (Hörman \& Hänninen, 2006; WHO, 2011). Microbial testing summarized in Table 11 show a total of 8 samples measured from January 12 - 19, 2012 from different water intake locations (3); 1 sample from Lake Amatitlán as a pollution guideline and a sample from Calderas elementary school water storage. Values from CWP, MWP, BWP, range from 4-5, 3-4, and 2 E. coli CFUs, respectively. Total coliform range as colony-forming units (CFU) were found from less than 40 up to 150 on all $1 \mathrm{ml} \mathrm{3M}$ Petrifilm ${ }^{\text {TM }}$ plates. The one Amati sample was taken from a random location on Lake Amatitlán, showing a bacteriological content of $9 \mathrm{E}$. coli and about 150 total coliform CFUs. The values from Amati sample were used as a microbial guideline for the samples measured at Calderas Lake intakes and Calderas elementary school (SS), respectively. The water sample collected at school reservoir found a total coliform content of 53 and 3 E. coli CFUs. Human and animal wastes are main causes of bacteriological contamination in water.

Table 11. Summary of total coliform and $E$. coli most probable number as colony forming units (CFUs).

\begin{tabular}{cccc}
\hline Date & Sample \# & E. coli & Total coliform \\
\hline \hline 12-Jan-12 & Amati & 9 & $\sim 150$ \\
13-Jan-12 & CWP-1 & 5 & $\sim 150$ \\
14-Jan-12 & MWP-1 & 3 & $\sim 150$ \\
15-Jan-12 & BWP-1 & 2 & $\sim 150$ \\
16-Jan-12 & CWP-2 & 4 & 87 \\
17-Jan-12 & MWP-2 & 4 & $<40$ \\
18-Jan-12 & BWP-2 & 2 & $<40$ \\
19-Jan-12 & Ss-12 & 3 & 53 \\
\hline
\end{tabular}

\section{Discussion}

\subsection{Water budget}

The water balance behavior for the 2012 period are presented in Figure 24. Mean annual precipitation for 2012 was $1198 \mathrm{~mm}$ and is to be considered drier than average compared to mean annual precipitations of previous years (2009, $1967 \mathrm{~mm}$; 
2010, $2428 \mathrm{~mm} ; 2011,1581 \mathrm{~mm})$. Likewise, for subsequent years (2013, 2014, 2015) the mean annual precipitation was 1094 mm, 1604 mm, and 1945 mm, respectively. Theoretically, lake depth measurements for 2012 were greater in contrast to the precipitation input for the study period. Lake depth measurements from June through January show increasing depth of $98 \mathrm{~cm}$ transitioning between wet to dry season. Figure 25 show the relationship between change in lake storage and recharge volumes for the study period. Linear regression between recharge and lake depth was applied to establish a recharge/seepage relation. The trend shows a negative correlation suggesting that infiltration occurring form recharge drains at a faster rate elsewhere once it percolates into soil. It is important to note that geological conditions (Eggers, 1975; Wunderman \& Rose, 1984) and Calderas watershed physical characteristics (described above) prompts such drainage pattern towards Amatitlán basin.

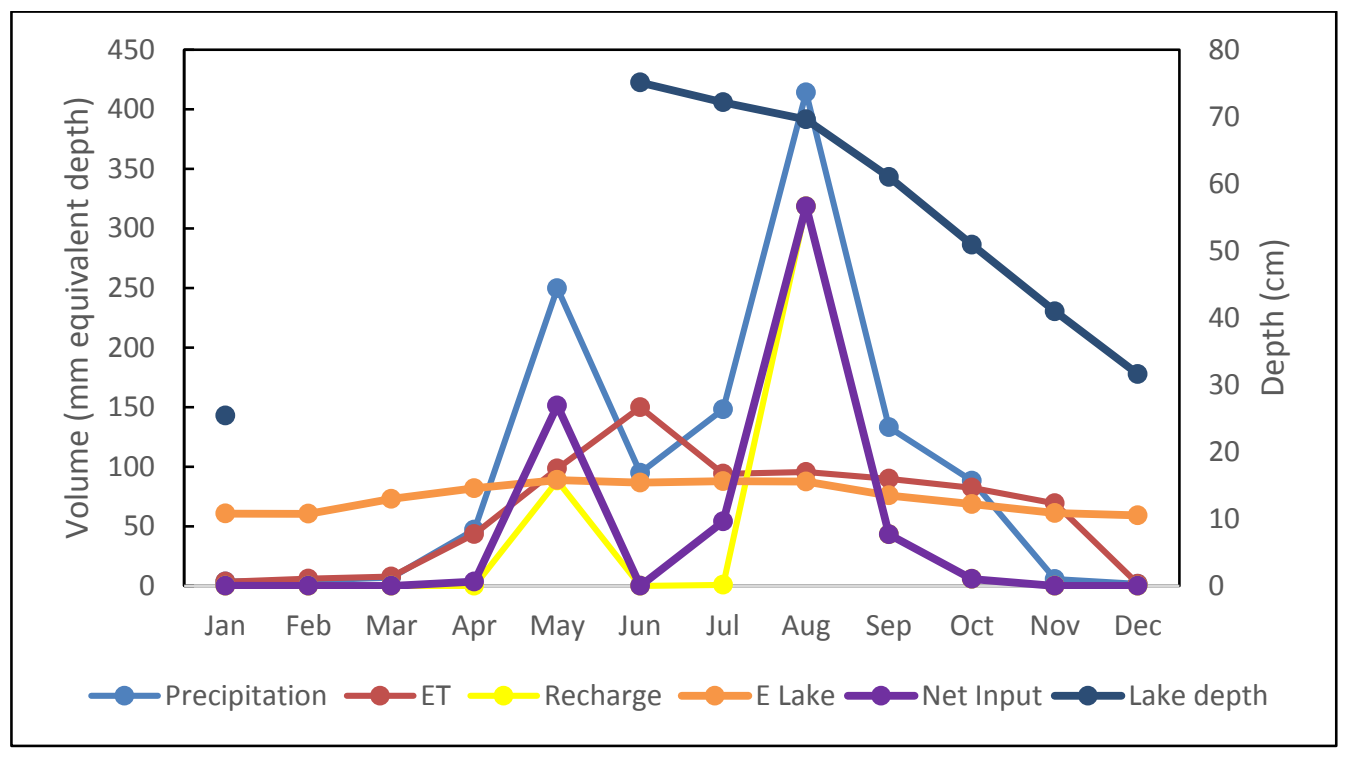

Figure 24. Thornthwaite Type monthly water balance for 2012. 


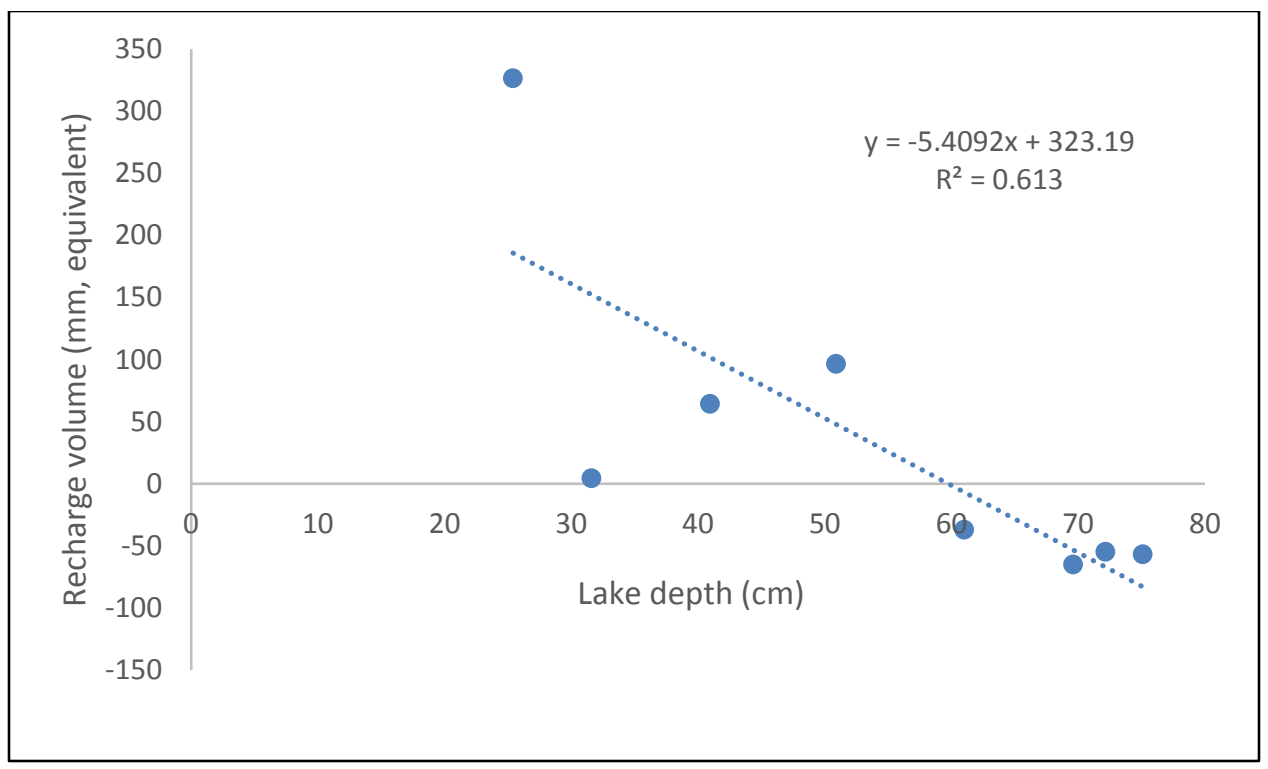

Figure 25. Linear regression plot between measured lake depth and estimated recharge after TMWB analysis for 2012 .

\subsection{Lake geochemistry and quality control}

Statistics of Calderas lake water quality samples are summarized in Table 12. The values obtained for each analytes were compared with previous studies and postfield processed dataset in relation to WHO (2011) drinking water permissible limits. Field measurements revealed no significant differences from initial to final measurements. Some parameters were not detectable by any of the testing methods, thus identified as $n / d$ in the reported table.

$\mathrm{pH}$ measurements are slightly basic, indicating no geothermal influence on the lagoon. Initial measurements of $\mathrm{pH}$ were recorded in July after several rainy days, reflecting high concentrations of surface runoff and less groundwater interaction. Higher $\mathrm{pH}$ measurements were obtained from august to December. Thus, no significant change was obtained, suggesting hydrogen equilibrium between aquatic biomass and aquifer rocks with no effect on the water quality intended for human consumption. No significant change was observed when comparing values with previous studies.

The TDS and conductivity during the transitional climate period showed no significant variation. TDS and conductivity values were measured from $182-256 \mathrm{mg} / \mathrm{l}$ and 278 - $394 \mu \mathrm{s} / \mathrm{cm}$, respectively. The values refer to low ionic concentrations in Calderas lake waters.

Alkalinity measurements ranged from 160 - 240 mg/l. Holding times increased when comparing with post-field measurements, analyte concentration values 
diminished. Alkalinity values processed at MTU ranged from $120-180 \mathrm{mg} / \mathrm{l}$ and 120 $-130 \mathrm{mg} / \mathrm{l}$ from DEQ results, respectively. However, the obtained values from the 3 subsets indicate presence of one or more ions in the water source regardless of the time in which the sample was processed.

Hardness is a property that increases boiling point of water and repels foam forming from soap and detergents. Measured hardness ranged from 175 - $425 \mathrm{mg} / \mathrm{l}$, with a mean of $247 \mathrm{mg} / \mathrm{l}$. High values of hardness often correlate with alkaline concentrations of dissolved solids within the water source. Results are acceptable within local and International drinking water quality standards.

Chloride is the anion associated with sodium chloride, potassium chloride and calcium chloride, which are attributed to salt dissolution from deposits beneath the surface. The range of chloride was found in all the samples as $7-21 \mathrm{mg} / \mathrm{l}$. It indicates the presence of salts of sodium $(\mathrm{NaCl})$, potassium $(\mathrm{KCl})$, and calcium $\left(\mathrm{CaCl}_{2}\right)$ from natural occurrence when limestone is the primary geologic source of a water system.

Increases in chloride concentrations from seasonal variation or through time are indicatives of human pollution or animal waste suggesting dissolution of human waste proximal to the water source of fertilizer runoff from agriculture. The values obtained do not represent toxic levels neither for the aquatic biomass nor for human consumption. Permissible volumes for chloride do not exceed $250 \mathrm{mg} / \mathrm{l}$ within the Guatemalan standards for human consumption. Since, chloride varies from lake to lake, it is important to establish a record for detecting and identifying sources of pollution in the future. 
Table 12. Mean $(\bar{X})$ and standard deviation $(\delta)$ of water quality parameters for field sampling, MTU laboratory processing, and DEQ subset in comparison to previous data from AMSA and who permissible limits.

\begin{tabular}{|c|c|c|c|c|c|c|c|c|c|}
\hline \multirow[b]{2}{*}{ Analyte } & \multirow[b]{2}{*}{$\begin{array}{c}\text { Who } \\
\text { limits }\end{array}$} & \multicolumn{2}{|c|}{ Field } & \multicolumn{2}{|c|}{ MTU lab. } & \multicolumn{2}{|c|}{ DEQ } & \multicolumn{2}{|c|}{ AMSA } \\
\hline & & $\bar{X}$ & $\delta$ & $\bar{X}$ & $\delta$ & $\bar{X}$ & $\delta$ & $\bar{X}$ & $\delta$ \\
\hline $\begin{array}{c}\text { Alkalinity } \\
(\mathrm{mg} / \mathrm{l})\end{array}$ & 150 & 189 & \pm 24 & 140.8 & \pm 12.7 & 127 & $\begin{array}{c} \pm \\
5.8\end{array}$ & - & - \\
\hline $\mathrm{pH}$ & $\begin{array}{l}6.5- \\
8.5\end{array}$ & 8.2 & \pm 1 & 8 & \pm 1 & - & - & 8.4 & \pm 0.4 \\
\hline $\begin{array}{l}\text { Phosphates } \\
(\mathrm{mg} / \mathrm{l})\end{array}$ & 10 & 5.9 & \pm 3.1 & - & - & $\mathrm{N} / \mathrm{d}$ & $\mathrm{N} / \mathrm{d}$ & 0.02 & \pm 0.1 \\
\hline $\begin{array}{l}\text { Hardness } \\
(\mathrm{mg} / \mathrm{l})\end{array}$ & 100 & 247 & \pm 62 & 157 & \pm 22 & 117 & $\begin{array}{c} \pm \\
1.2\end{array}$ & 138 & \pm 26.4 \\
\hline$\underset{(\mathrm{mg} / \mathrm{l})}{\text { Chloride }}$ & 500 & 14 & \pm 3.4 & - & - & 20 & $\begin{array}{c} \pm \\
0.6\end{array}$ & - & - \\
\hline Salinity (\%) & 0.1 & 0.003 & 0 & - & - & - & - & - & - \\
\hline $\begin{array}{l}\text { Sodium } \\
(\mathrm{mg} / \mathrm{l})\end{array}$ & 200 & - & - & - & - & 18 & $\begin{array}{c} \pm \\
0.6\end{array}$ & - & - \\
\hline Nitrite (mg/l) & 0.1 & $\mathrm{~N} / \mathrm{d}$ & $\mathrm{N} / \mathrm{d}$ & $\mathrm{N} / \mathrm{d}$ & $\mathrm{N} / \mathrm{d}$ & $\mathrm{N} / \mathrm{d}$ & $\mathrm{N} / \mathrm{d}$ & 0.2 & \pm 0.2 \\
\hline $\begin{array}{c}\text { Nitrate } \\
(\mathrm{mg} / \mathrm{l})\end{array}$ & 10 & 0.1 & \pm 0.2 & $\mathrm{~N} / \mathrm{d}$ & $\mathrm{N} / \mathrm{d}$ & $\mathrm{N} / \mathrm{d}$ & $\mathrm{N} / \mathrm{d}$ & 0.02 & \pm 0.002 \\
\hline$\underset{(\mathrm{mg} / \mathrm{l})}{\operatorname{Ammonia}}$ & 1 & 0.1 & \pm 0.2 & $\mathrm{~N} / \mathrm{d}$ & $\mathrm{N} / \mathrm{d}$ & - & - & 0.1 & \pm 0.1 \\
\hline Iron $(\mathrm{mg} / \mathrm{l})$ & 0.1 & $\mathrm{~N} / \mathrm{d}$ & $\mathrm{N} / \mathrm{d}$ & $\mathrm{N} / \mathrm{d}$ & $\mathrm{N} / \mathrm{d}$ & $\mathrm{N} / \mathrm{d}$ & $\mathrm{N} / \mathrm{d}$ & 0.1 & \pm 0.01 \\
\hline TDS (mg/l) & 300 & - & - & 217 & \pm 15 & - & - & 294 & \pm 47 \\
\hline $\begin{array}{l}\text { Conductivity } \\
(\mu / \mathrm{cm})\end{array}$ & $<1000$ & - & - & 334 & \pm 24 & 362 & \pm 12 & 342 & \pm 67 \\
\hline $\begin{array}{l}\text { Fluoride } \\
(\mathrm{mg} / \mathrm{l})\end{array}$ & 1.5 & - & - & - & - & 1 & $\begin{array}{c} \pm \\
0.02\end{array}$ & - & - \\
\hline
\end{tabular}

In accordance with WHO drinking water standards (2011), the chemical components of Calderas Lake are within acceptable limits for human consumption. Since the geology of the area is mostly from volcanic origin, it is not expected to be a pollution source. Henceforth, this area is covered by tephra and volcanic deposits, the proposed water budget suggests a fast rate seepage and infiltration volumes making dissolution and interaction of minerals highly improbable within reservoir. 


\subsection{Water budget vs. consumption rates}

The TMWB aided in establish an input-output relation at Calderas watershed. Such relation is estimated to be $52 \%$ of inputs which are: 1 ) precipitation falling onto the watershed area, and 2) precipitation falling onto Calderas Lake. Outputs are estimated to be $48 \%$ including lake evaporation, watershed evapotranspiration and community withdrawals. These community withdrawals estimations reflect only on Calderas community and are based on pumping rates, tank storage dimensions and several assumptions from visual observations during time in site (see section $\mathbf{3 . 3}$ for estimation rationale and methods).

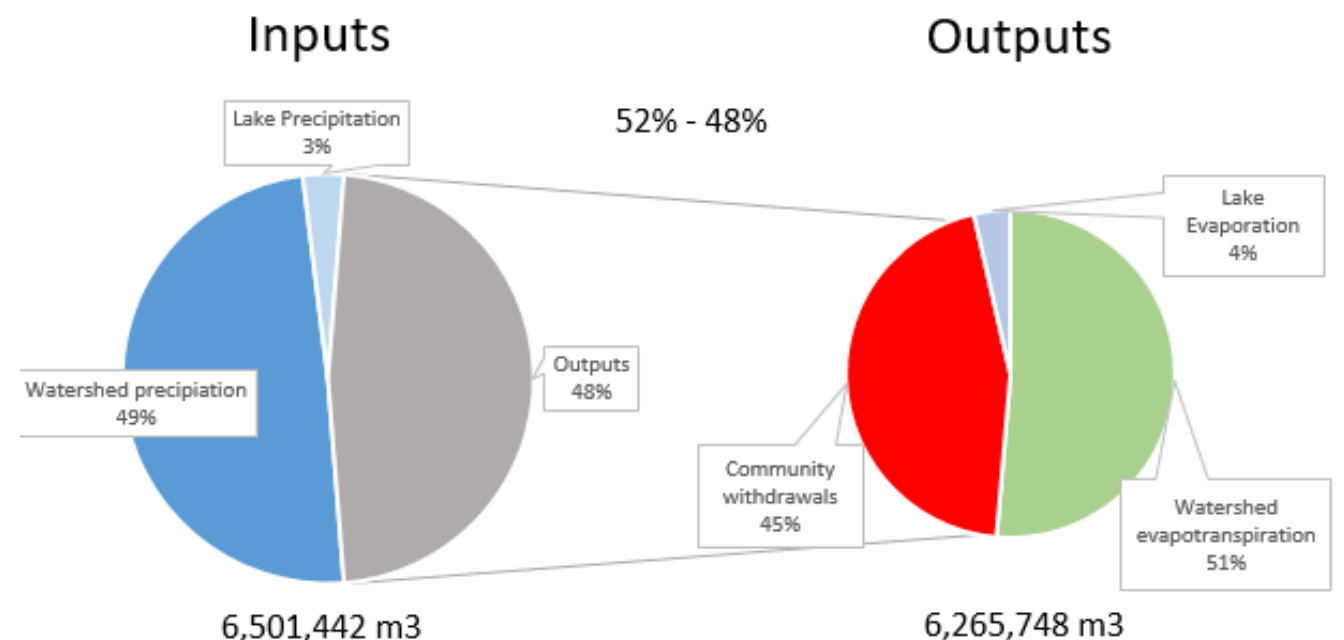

Figure 26. Input-output relationship pie chart for Calderas lake. Total inputs are derived from total precipitation falling onto the watershed. Outputs reflect estimations from TMWB (lake evaporation and watershed evapotranspiration) and local estimations on community withdrawals.

The relationship between inputs and outputs for Calderas watershed seems to be in balance. However, once outputs exceed input volumes the overall quantity and quality of Calderas Lake will become jeopardized affecting its natural system and all the beneficiaries of such resource. Discussions between community leaders, local authorities and decision makers must be made for establishing withdrawal estimates from other intakes. Inferences can be made from our water budget estimation:

a) Outputs are equilibrating with inputs.

b) There is enough surplus for replenishing and recharging the system. 


\section{Calderas hydrological interpretation}

The water budget and water quality analysis suggest a quick lake recharge and drainage through groundwater seepage. Such dynamic behavior is governed by a shallow unconfined aquifer at mid to late Pleistocene tephra and ash deposits (Koch, 1975). Water transmissibility is high on tephra and ash deposits, porosities percentages on such units typically range from $15 \%$ to $50 \%$ (Dinwiddie et al., 2012) leading to fast drainage and infiltration ratio from higher to lower elevations and into the upper Michatoya basin. The area is dominated by a series of N-S faults identified by Eggers (1975) and visually interpreted from satellite imagery (Figure 27) which separates the shallow unconfined aquifer that supplies the lake with other deep confined hydrological units. Yet, the existence of a geothermal plant in the area proves the existence of such deeper aquifer within the basin. This contrasts with the location of Calderas micro-basin within the Amatitlán cauldron serving as a drainage divide between the upper and lower Michatoya sub-basins. Figure 28 show a cross-section interpretation of the groundwater behavior at Calderas micro-basin.

The TMWB estimates intend to predict a baseline hydrologic scenario for Calderas micro-basin in terms of the amount of water that influence the system. The available volume for system recharge is then estimated through net precipitation. Such volume can reach up to $25 \%$ of the total input as rainfall; neglecting the amount of groundwater that recharges the system. With this value in mind, one can assume that about a quarter of the total input as surplus is responsible for recharging the lake as it drains to lower elevations due to the geological conditions that govern the area. 


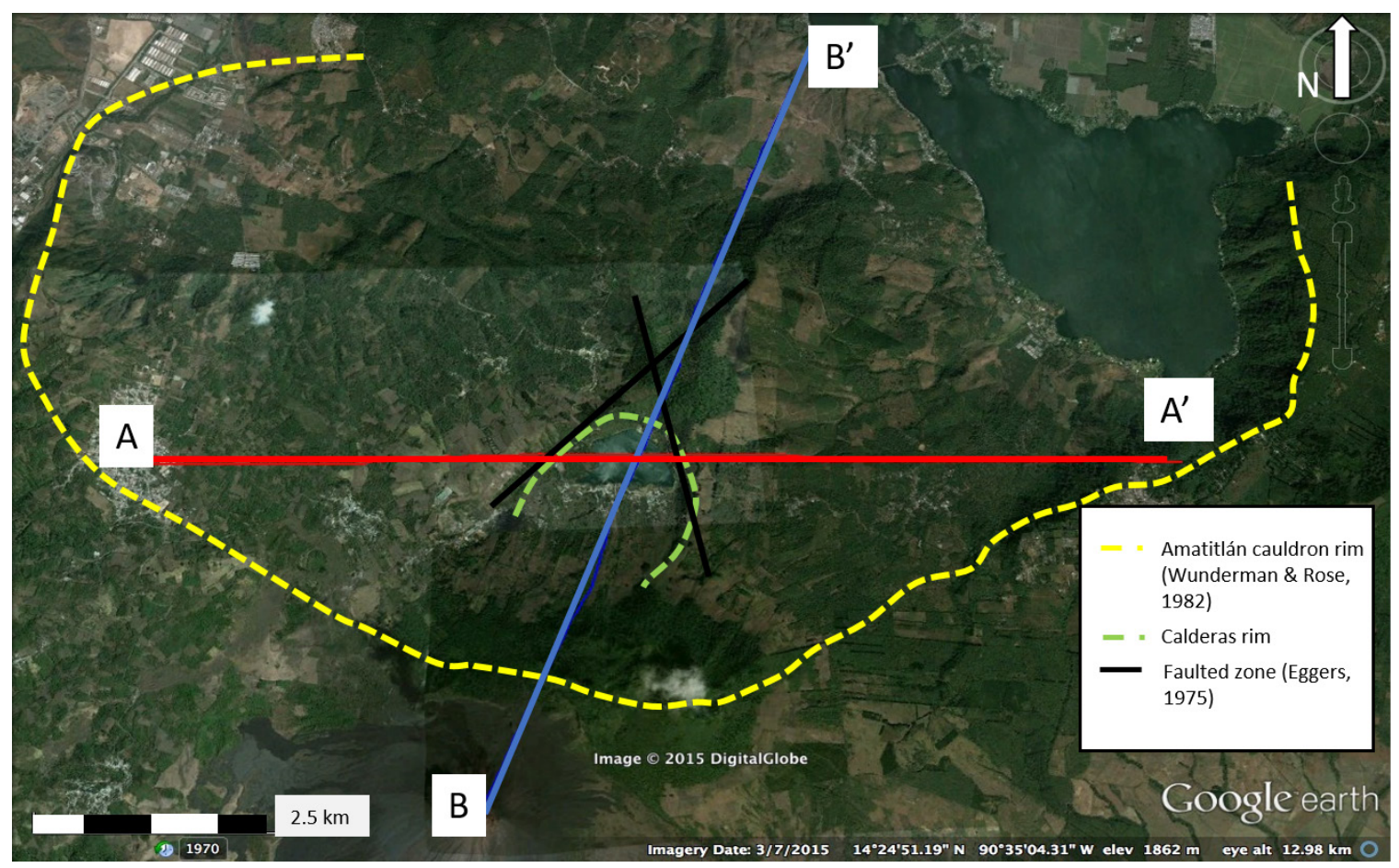

Figure 27. Satellite view of the area showing Amatitlán cauldron (dashed yellow) after Wunderman \& Rose (1982), fault zones (black) mapped by Eggers (1975) and Calderas microbasin (dashed green) within the system. Cross-section profiles from $W$ to $E$ and $S$ to $N$, profile intersection at Calderas lake (modified from Google Earth).

Lake geochemistry offer clues about the chemical components present in Calderas lake as well as the aquifer seepage interaction. Measured parameters lead to various interpretations:

a) No chemical analyte concentration build-up within the study period reveal a fast drainage as the lake recharges. Regardless of the evident anthropogenic interaction.

b) The aquatic biomass aid in processing anthropogenic pollutants as the water constantly drains through the porous and fractured substrate.

c) No water mixture between aquifers occurs, since analytes remained constant at low concentrations. pH concentrations (8) were slightly alkaline during study period.

Figure 28a show a vertical profile from San Vicente (west) to southeast Amatitlán cauldron wall on an approximately $10-\mathrm{km}$ distance. Water percolates the substrate as it drains from higher to lower gradients replenishing the shallow aquifer that recharges Calderas Lake. According to Ríos-Sánchez (2012), this groundwater behavior can be interpreted as a local flow system, occurring at elevations ranging 
1600 - 1750 masl. In the same context figure 28b, the profile line has been drawn from Pacaya volcano main vent (south) towards Amatitlán narrowest channel (north) at a $9.5 \mathrm{~km}$ distance. From the main vent, water drains to lower elevations onto the upper Michatoya basin being Cerro Grande the drainage divide between Calderas micro-basin and upper Michatoya basin. Beyond Cerro Grande in the N direction water infiltrate, supply the shallow aquifer continuing its drainage vertically underground towards Amatitlán Lake. In accordance to Ríos-Sánchez (2012), groundwater reaching greater depths drains at a slower rate towards lower elevations affecting its mineral composition and residence time classifying this flow regime as regional flow systems.

\section{Anthropogenic activity}

The quantities estimated by the TMWB components reflect on our understanding of why the visual anthropogenic based influence in the lake/watershed were not identified by the partial chemistry methods. During, wet months the interaction between seeped and stored water may reduce and wash pollutant concentrations through quick drainage towards lower elevations. Yet, such drainage behavior acting as a "flush" doesn't seem to take effect on microbiological pollutants due to its continuous infiltration from community latrines.

E. coli and total coliform tests prove that water is contaminated by biological pathogens on every sampled intake. Total coliform and E. coli CPUs found at every sample exceed the drinking quality parameters established by national and international regulations. The consumption of untreated water from Calderas Lake could trigger serious health and gastrointestinal issues within the consumers if levels of bacteria keep rising within time. 

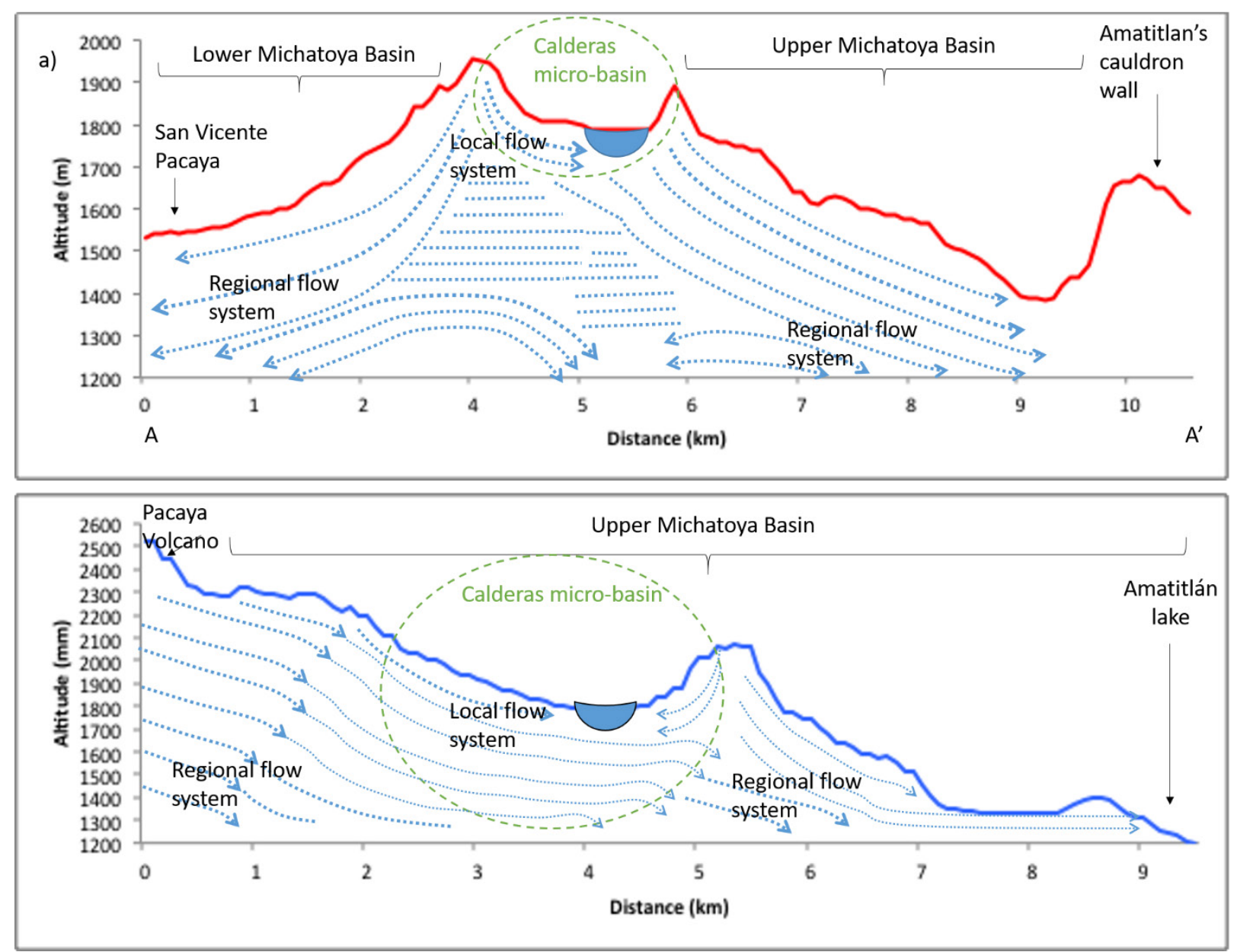

Figure 28. a) A-A' cross-section from San Vicente (W) to Amatitlán cauldron wall (E). Interpretation of groundwater behavior based (Rios-Sanchez et al., 2012) groundwater flow regimes, Calderas water budget and geochemical analysis. b) B-B' cross-section and hydrological interpretation from Pacaya volcano (S) to Amatitlán lake ( $\mathbf{N})$. 
Lack of urban drainage in Calderas community jeopardize the lake water quality for future generations. The community sewage system are latrines, considering the fast drainage estimated by the TMWB is no surprise that most of these pathological indicators drain towards the lake easily. Visually, fecal matter from cattle and domestic animals are also observed around the populated shore of Calderas Lake (Figure 29a). Another pollutant component from human activity are discharge house pipes into the lake (Figure 29b). Despite the fast drainage of the lake, excess of contaminants and pollutants from human activities are a threat to the water quality and trophic state of Calderas Lake. The aquatic biomass is currently processing the chemical inputs from natural and human activities in a satisfactory way. However, if no action plan is taken within the near future, overall degradation of the water system is to become imminent. Considering Calderas Lake as the only water source at such elevations and for a considerable population. The effects of system degradation can trigger negative impacts to the health and lifestyle of the consumers.

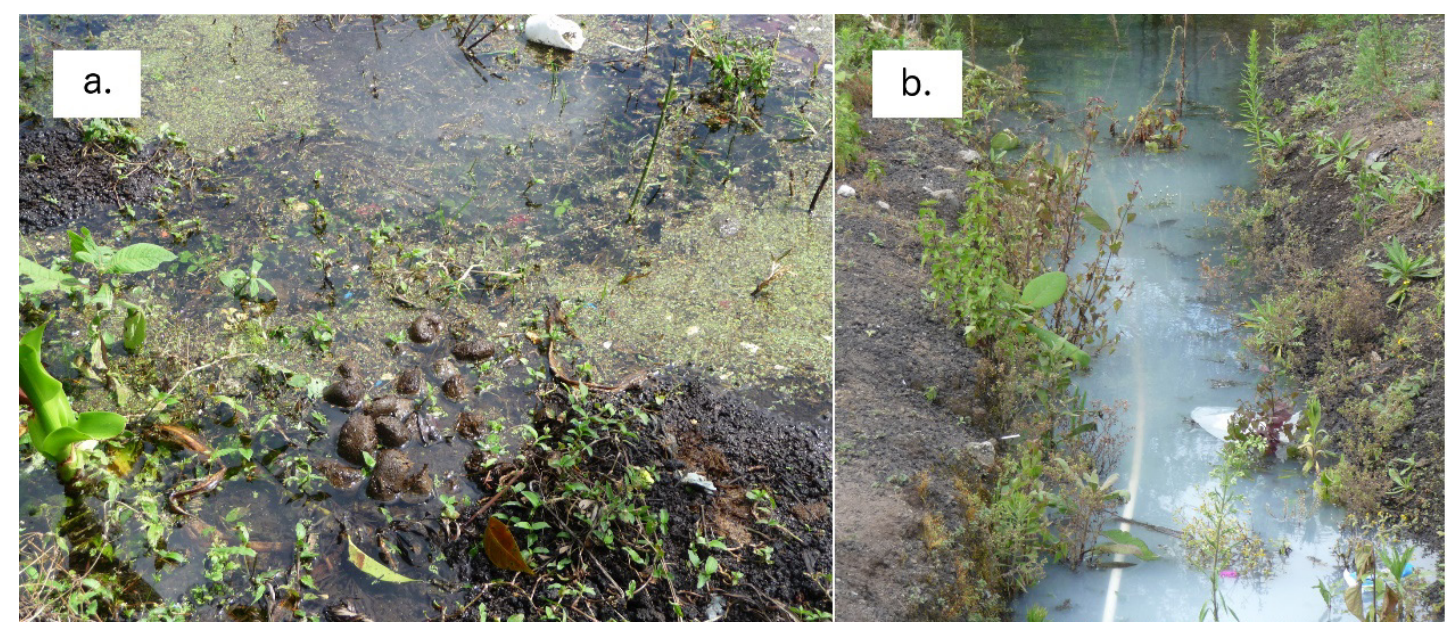

Figure 29. a) Septic contamination from cattle around Calderas Lake shoreline. b) House drainage into the lake (photo: author) 


\section{Conclusions}

The objectives of the study were to characterize the hydrology, quantify the water budget, and establish a water quality relationship for a small but geologically complex area of Pacaya Volcano and Calderas Lake National Park in Guatemala. Hydrologic parameters including precipitation, recharge, lake evaporation and PET (as a baseline for $A E T$ ) have been estimated for a 7-year period. A Thornthwaite mean monthly water budget model with three other pet model was evaluated to Calderas micro-basin to estimate monthly aet values during the study period and to predict water surpluses in relation to lake behavior dynamics. Lake partial chemistry sampling, microbiological tests, GIS processing and interpretation, and visual observtions aid in compile sufficent data to provide a baseline hydrologic analysis that can serve as a reference for community members o leaders concerned with water resources (quality, quantity and distribution) and the impacts of land management and antropogenic activities inside the watershed.

The Hamon, Blaney-Criddle, Papadakis equations for estimating lake evaporation $\left(E_{L}\right)$ are embedded within the Thornthwaite monthly water budget producing reliable results with regression coefficients $\left(R^{2}\right) 0.8$ for Blaney-Criddle, and 0.03 for Papadakis. Considering the lack of climate data from stations near study area and missing groundwater information, $E_{L}$ values were obtained within the expected range for a sub-tropical humid zone. Hamon method was chosen because it estimated an intermediate value in comparison to the other methods. Net precipitation was calculated to obtain a volume that could contrast the water availability for recharging the lake considering approximate amount of withdrawals for human consumption. Generally, the water budget predicts a $25 \%$ surplus for any given year with a mean annual precipitation above $1000 \mathrm{~mm}$ of rainfall.

Partial chemistry analysis helped to understand the behavior between lake recharge and aquifer transmisibility during a 6-month study period in 2012. Results did not reveal significant changes for $\mathrm{pH}$, alkalinity, hardness, chloride, phosphates, tds and conductivity during the wet to dry transisional seasons. However, when compared with previous studies, field results increased for $\mathrm{pH}$, hardness, tds and conductivity. When comparing the water budget with the partial chemistry, one can assume that Calderas micro-basin drains at a fast rate because no significant changes were observed on the partial chemistry analysis. Also, the geological units mapped by Eggers (1975) and described by Bardzintdeff (1992), Wunderman \& Rose (1982) and 
Koch (1975) suggest a highly porous and fractured media where groundwater can drain easily. Naturally, the geology governing Calderas watershed is not polluting neither the lake nor the aquifer. Yet, contamination from human impact is affecting the overall quality of the lake as time passes by. Surpisingly, during the wet season recharge, drainage and aquatic biomass interaction aid in reducing pollutants in the lake due to fast drainage into the upper michatoya basin. Despite the quick "flush" of Calderas lake for partial chemistry, it does not treat the microbiological indicators the same way due to its continous interaction of fecal matter from community latrines with the unconfined shalow aquifer. These bateria percolates the substrate reaching Calderas lake as groundwater recharges the system. Hydrologically, Calderas basin is governed by a local flow system on its shallow aquifer swithching to a regional flow system as it drains towads Amatitlán lake. Magmatism, horst-faults and fractured lavas are key in confining aquifers for geothermal explotation within the basin area. Partial chemistry results did not reveal deep to shallow aquifer mixing during the recharge process of Calderas lake. Chemically, Calderas lake water is suitable for human consupmtion in accordance to WHO, COGUANOR, EPA and other international drinking water standards after dessinfection.

Petri films where used to identify E. coli and total coliforms as CPUs around the intakes of the lake and within the storages intended for human comsumption. Results revealed the presence of biological pathogens on every measured sample. Regradless the chemically acepted parameters for human consumption, Calderas lake water can thread consumers with gastrointestinal diseases if not treated correctly. Many forms of contamination are responsible for biologically polluting the water, therefore, the many latrines existing on every household in the community and the fast drainage and percolation rate seem to be the main input on such biological pollutants.

The quantities estimated by the TMWB components reflect on our understanding of why the visual anthropogenic based influence in the lake/watershed that were not identified by the partial chemistry methods. During, wet months the interaction between seeped and stored water may reduce and wash pollutant concentrations through quick drainage towards lower elevations. Yet, such drainage behavior acting as a "flush" does not seem to take effect on microbiological pollutants found at the lake due to continuous interaction between fecal matter with the shallow aquifer from community latrines. 
Inferences can be made about lake productivity with antropogenic interaction and the hydrological conditions of the watershed. If no management plan is developed in the near future, Calderas lake can reach eutrophication making the lake useless for human consumtion and stressing the water availability for more than 17,000 consumers within the nearby area.

\section{Limitations}

Long-term datasets are necessary to place results in context with quality alterations from seasonal variability or climate change in general. Yet, the results obtained in this research complement and aggregate on the general knowledge of the water quality of Laguna Calderas. The physical properties of the catchment installs the basis for assesing water contamination and water resource management. The analysis carried out in this report can be further reproduced with local datasets for futher monitoring and understanding of the water resources in response to human consumption and potential climate change.

The water quality results reported in this investigation interpret the condition of Calderas water at the time of sampling and are expected to be variable from time to time, including: days, seasons and years. Six months of sampling may be sufficient for determining the water quality over the wet season. However, specific parameters are needed to be addressed and extensive laboratory analisys must be made in order to establish a record and incorporate a water management plan.

The TMWB have shown its ability to simulate watershed hydrology and can be applied to address a wide-range of environmental and water-resources issues. Thus, more parameters and inputs must be collected in order to enhance the model for better understanding of the hydrogeology of the area. Information like, hydraulic conductivity, drainage density, groundwater depth and actual extracted volumes from beneficiaries can yield to more information about the catchment characteristics in response to human consumption and its bio-geological components.

\section{Future Work}

This study resulted in the first water balance estimation at Calderas Lake. In order to assess a complete hydrological profile, groundwater isotopes studies should be combined with soil infiltration assessments for determining a groundwater age, rate of circulation, and have a better understanding of Calderas lake recharge ratio, mixing and interaction with groundwater. 
Furthermore, similar detailed water geochemistry studies on a periodic sampling rate should lead to establish a water quality database over the long time period. This could reveal information on lake bio-geochemical interaction for determining euthrophication levels. Also, a well established database could lead to interpret and understand other sources of contamination influenced naturally or by anthropogenic activities.

Finally, this work could serve as a foundation for long-term hydrological and water quality monitoring for Calderas watershed. By continuous repetition of water quality studies, groundwater isotopes analyses and in-site weather data collection, specially during rainy seasons and periods of volcanic unrest, groundwater mixing and interaction along the Calderas micro-basin can be studied, as well as a possible influence from geothermal infiltration and aquifer mixing due to fault and fractured geological units on Pacaya hydrothermal system.

Some procedures that could be done to improve and enhance similar projects are:

- Installation of weather stations (precipitation gages and termometers), for ensuring accuracy of model inputs and to establish a historical dataset.

- Core drilling and soil sampling, to characterize the groundwater profile and performance of isotopic analysis of groundwater to precisely determine Calderas Lake aquifer origins.

- Periodical geochemistry sampling, to establish a record for identifying potential trends that could affect the water source.

- Surface water level monitoring, for establishing critical and optimal volumes of water storage. A basic and important parameter for monitoring water sources used for human consumption. 


\section{References}

Abtew, W. (2001). Evaporation estimation for Lake Okeechobee in south Florida. Journal of Irrigation and Drainage Engineering, 127(3), 140-147.

Allen, R. G., Pereira, L. S., Raes, D., \& Smith, M. (1998). Crop evapotranspirationGuidelines for computing crop water requirements-FAO Irrigation and drainage paper 56. FAO, Rome, 300(9), D05109.

Alley, W. M. (1984). On the Treatment of Evapotranspiration, Soil Moisture Accounting, and Aquifer Recharge in Monthly Water Balance Models. Water Resources Research, 20(8), 1137-1149. doi:10.1029/WR020i008p01137

Bardintzeff, J. M., Deniel, C. (1992). Magmatic evolution of Pacaya and Cerro Chiquito volcanological complex, Guatemala. Bulletin of volcanology, 54(4), 267-283.

Borović, S., \& Marković, I. (2015). Utilization and tourism valorisation of geothermal waters in Croatia. Renewable and Sustainable Energy Reviews, 44, 52-63.

Brown, M. E., Pinzón, J. E., Didan, K., Morisette, J. T., \& Tucker, C. J. (2006). Evaluation of the consistency of long-term NDVI time series derived from AVHRR, SPOT-Vegetation, SeaWiFS, MODIS, and Landsat ETM+ sensors. Geoscience and Remote Sensing, IEEE Transactions on, 44(7), 1787-1793.

Burkart, B., \& Self, S. (1985). Extension and rotation of crustal blocks in northern Central America and effect on the volcanic arc. Geology, 13(1), 22-26. doi: 10.1130/0091-7613(1985)13<22: earocb $>2.0 . c 0 ; 2$

Capuchino, A., Lara, B., Nagaraje Urs, P., Lehmann, M., \& Sharma, A. (2008). Amatitlán Geothermal Project in Guatemala (2007-1945). Retrieved from

Carlson, T. N., \& Ripley, D. A. (1997). On the relation between NDVI, fractional vegetation cover, and leaf area index. Remote Sensing of Environment, 62(3), 241-252. doi: http://dx.doi.org/10.1016/S0034-4257(97)00104-1

Carr, M. J. (1976). Underthrusting and Quaternary faulting in northern Central America. Geological Society of America Bulletin, 87(5), 825-829. doi:10.1130/0016-7606(1976)87<825:uaqfin>2.0.c0;2

Carr, M. J. (1984). Symmetrical and segmented variation of physical and geochemical characteristics of the Central American volcanic front. J. Volcanol. Geotherm. Res., 20, 231-252.

Norma Guatemalteca Obligatoria, 29001.99 C.F.R. (1999).

Conway, F., Diehl, J., \& Matías, O. (1992). Paleomagnetic constraints on eruption patterns at the Pacaya composite volcano, Guatemala. Bulletin of volcanology, 55(1-2), 25-32. doi:10.1007/bf00301117

Dingman, S. L. (2002). Physical Hydrology. New Jersey: Prentice Hall. 
Dinwiddie, C. L., Bradbury, K. K., McGinnis, R. N., Stillman, D. E., \& Ferrill, D. A. (2012). Hydrogeologic heterogeneity of faulted and fractured Glass Mountain bedded tuffaceous sediments and ash-fall deposits: The Crucifix site near Bishop, California. Lithosphere, 4(1), 40-62.

Eckner, K. F. (1998). Comparison of Membrane Filtration and Multiple-Tube Fermentation by the Colilert and Enterolert Methods for Detection of Waterborne Coliform Bacteria, Escherichia coli, and Enterococci Used in Drinking and Bathing Water Quality Monitoring in Southern Sweden. Applied and Environmental Microbiology, 64(8), 3079-3083.

Eggers, A. (1972). The geology and petrology of the Amatitlán Quadrangle,

Guatemala. (PhD Dissertation), Dartmouth College.

Eggers, A. (Cartographer). (1975). Geological Map of the Amatitlán 1:50,000 Quadrangle, Guatemala

Fajardo Gil, O. (2010). Tierra de Amatles: Monografía del Municipio de Amatilán. In G. Municipalidad de Amatitlán (Ed.), http://issuu.com/muniamatitlan/docs/www.amatitlan.gob.gt. Guatemala: Impresiones EG.

Fish, R. E. (2011). Using Water Balance Models to Approximate the Effects of Climate Change on Spring Catchment Discharge: Mt. Hanang, Tanzania. (M.Sc.), Michigan Technological University. (65)

García García, H. O. (2002). Cuantificación de la calidad de agua del río Villalobos en época seca y lluviosa en un periodo de 24 horas, 2 veces al mes en un punto previo a la entrada al lago de Amatitlán. (M.Sc.), Universidad de San Carlos de Guatemala. Retrieved from http://www.bvsde.paho.org/bvsatesis/hgarcia.pdf

Gomez, R. O. M., Rose, W. I., Palma, J. L., \& Escobar-Wolf, R. (2012). Notes on a Map of the 1961-2010 Eruptions of Volcán de Pacaya, Guatemala. The Geological Society of America, Digital Map and Chart Series 10, 10. doi:10.1130/2012.DMCH010

Groshong, R. H. (2006). 3-D Structural Geology A Practical Guide to Quantitative Surface and Subsurface Map Interpretation (pp. P. 221). Retrieved from http://books.google.com/books?id=9-

m5kLdDCQ8C\&printsec $=$ frontcover\&dq =inauthor:\%22Richard $+\mathrm{H} .+$ Groshong $\% 22 \& h l=e s-419 \& s a=X \& e i=e g 7 P U 6$ oC4-

TyATntIL4CQ\&ved=0CCQQ6AEwAQ\#v=onepage\&q\&f=false

GWP, C. A. (2011). Situación de los Recursos Hídricos de Centro América: Hacia una Gestión Integrada. Retrieved from Tegucigalpa, Honduras:

Hörman, A., \& Hänninen, M.-L. (2006). Evaluation of the lactose Tergitol-7, m-Endo LES, Colilert 18, Readycult Coliforms 100, Water-Check-100, 3M Petrifilm EC and DryCult Coliform test methods for detection of total coliforms and Escherichia coli in water samples. Water Research, 40(17), 3249-3256. doi:http://dx.doi.org/10.1016/j.watres.2006.06.024 
Illman, D. L. (2006). Water analysis in the developing world. Analytical chemistry, 78(15), 5266-5272.

Jackson, R. B., Canadell, J., Ehleringer, J. R., Mooney, H. A., Sala, O. E., \& Schulze, E. D. (1996). A global analysis of root distributions for terrestrial biomes. Oecologia, 108(3), 389-411. doi:10.1007/BF00333714

Janetos, A., \& Justice, C. (2000). Land cover and global productivity: A measurement strategy for the NASA programme. International Journal of Remote Sensing, 21(6-7), 1491-1512.

Koch, A. J., McLean, H. (1975). Pleistocene Tephra and Ash-Flow Deposits in the Volcanic Highlands of Guatemala. Geological Society of America Bulletin, 86(4), 529-541. doi:10.1130/0016-7606(1975)86<529:ptaadi>2.0.co;2

Kucharski, M. J. (2010). A Conceptual Model of Groundwater Flow to Spirngs in BanUtod and Cagnonoc Watersheds, Baybay, Leyte, Philippines. (M.Sc. Report), Michigan Technological University.

Lima Lobato, E. M., Fujino, T., and J.C. Palma Ayala. (2000). Amatitlan Geothermal Field in Guatemala. Geothermal Resources Council Bulletin, 29, 215-220.

Lira Prera, E. E. (2005). Propuesta de Ordenamiento Territorial del Parque Nacional Volcán Pacaya. (Engr. Agrónomo en Recursos Naturales Renovables), Universidad de San Carlos de Guatemala, Instituto de Investigaciones Agronómicas.

Lu, J., Sun, G., McNulty, S. G., \& Amatya, D. M. (2005). A Comparisom of Six Potential Evapotranspiration Methods for Regional Use in the Southeastern United States. JAWRA Journal of the American Water Resources Association, 41(3), 621-633. doi:10.1111/j.1752-1688.2005.tb03759.x

Lyon-Caen, H., Barrier, E., Lasserre, C., Franco, A., Arzu, I., Chiquin, L., . . . Wolf, R. (2006). Kinematics of the North American-Caribbean-Cocos plates in Central America from new GPS measurements across the Polochic-Motagua fault system. Geophysical Research Letters, 33(19), L19309. doi:10.1029/2006GL027694

M.A.R.N. (2011). Cuencas Hidrográficas de Guatemala. Retrieved from Guatemala:

Manafi, M. (1996). Fluorogenic and chromogenic enzyme substrates in culture media and identification tests. International Journal of Food Microbiology, 31(1-3), 45-58. doi:http://dx.doi.org/10.1016/0168-1605(96)00963-4

Marroquín Guerra, E. d. L. (2008). Determinación de variables físicas, químicas y biológicas del recurso hídrico de la Laguna de Calderas. (M.Sc.), Universidad de San Carlos de Guatemala, Web. Retrieved from http://biblioteca.usac.edu.gt/tesis/08/08 0159 MT.pdf

Mattelet, C. (2006). Household ceramic water filter evaluation using three simple lowcost methods: membrane filtration, 3M Petrifilm and hydrogen sulfide bacteria in northern region, Ghana. Massachusetts Institute of Technology. 
Medina, C., Gomez-Enri, J., Alonso, J. J., \& Villares, P. (2010). Water volume variations in Lake Izabal (Guatemala) from in situ measurements and ENVISAT Radar Altimeter (RA-2) and Advanced Synthetic Aperture Radar (ASAR) data products. Journal of Hydrology, 382(1), 34-48.

Minervini, B. E. (2005). Geothermal tourist park in Berlín field, El Salvador: assessment on the use of geothermal brine for bathing and spa. Geothermal Training Programme, Reports 2005(13).

Ministerio de Agricultura, G. y. A. (2000). Primera Aproximación al Mapa de Clasificación Taxonómica de los suelos de la República de Guatemala, a escala 1:250,00 -Memoria Técnica-. Retrieved from Guatemala:

Pereira Rodas, L. F. (1990). Plan preliminar para el manejo de la microcuenca de la laguna de Calderas, Guatemala. Universidad de San Carlos de Guatemala, Guatemala. Retrieved from http://biblioteca.usac.edu.gt/tesis/01/01 1212.pdf

Rao, L., Sun, G., Ford, C., \& Vose, J. (2011). Modeling potential evapotranspiration of two forested watersheds in the southern Appalachians. Transactions of the ASABE, 54(6), 2067-2078.

Rios-Sanchez, M., Gierke, J. S., \& Muñoz-Martínez, T. (2012). Hydrogeological Characterization of the Plateaus Region of the Quito Aquifer System Using Remote Sensing, Digital Geomorphology, and Geophysics. Paper presented at the World Environmental and Water Resources Congress 2012: Crossing Boundaries.

Rosenberry, D. O., Winter, T. C., Buso, D. C., \& Likens, G. E. (2007). Comparison of 15 evaporation methods applied to a small mountain lake in the northeastern USA. Journal of Hydrology, 340(3), 149-166.

Seib, M. D. (2011). Assesing drinking water quality at source and point-of-use: A case study of Koila Bamana, Mali, West Africa. (M.Sc. Master's report), Michigan Technological University.

Shonsey, C. W. (2009). Quantifying Available Water at the Village Level: A case Study of Horongo, Mali, West Africa. (M.Sc. Report), Michigan Technological University.

UNICEF. (2012). Varios países están logrando rápidos progresos en la supervivenvia infantil [Press release]. Retrieved from http://www.unicef.org.gt/2 sala de prensa/comunicados/comunicados2012/ Comunicado Supervivencia Infantil 130912.pdf

USDA, N. (1999). Soil Taxonomy: A Basic System of Soil Classification for Making and Interpreting Soil Surveys. 2nd ed.

Van Der Pluijm, B., \& Marshak, S. (2004). Earth Structure : Introduction to Structural Geology and Tectonics Second Edition. USA: W.W. Norton and Company.

Villagrán, J., Castillo, Z., Pineda, O., Zabaleta, J., Aguilar, L. (2012). Análisis Físicoquímico y Microbiológico del Sistema de Distribución de Agua Potable en Aldea Calderas, Amatitlán. Retrieved from 
Wang, Q., Adiku, S., Tenhunen, J., \& Granier, A. (2005). On the relationship of NDVI with leaf area index in a deciduous forest site. Remote sensing of environment, 94(2), 244-255.

Westenbroek, S. M., Kelson, V., Dripps, W., Hunt, R., \& Bradbury, K. (2010). SWB--a Modified Thornthwaite-Mather Soil-Water-Balance Code for Estimating Groundwater Recharge: US Department of the Interior, US Geological Survey, Ground Resources Program.

WHO. (1996). Water Quality Assessments - A Guide to use Biota, Sediments and Water in Environmental Monitoring - Second Edition. Retrieved from E\&FN Spon, Cambridge UK: http://www.who.int/water sanitation health/resourcesquality/watqualassess. $\underline{\mathrm{pdf}}$

WHO. (2011). Guidelines for Drinking-water Quality - 4th ed. Retrieved from Switzerland:

Winter, T. C. (1999). Relation of streams, lakes, and wetlands to groundwater flow systems. Hydrogeology Journal, 7(1), 28-45.

Wunderman, R. L., \& Rose, W. I. (1984). Amatitlan, An actively resurging cauldron 10 km south of Guatemala City. Journal of Geophysical Research: Solid Earth, 89(B10), 8525-8539. doi:10.1029/JB089iB10p08525

Xu, C. Y., \& Singh, V. (2001). Evaluation and generalization of temperature-based methods for calculating evaporation. Hydrological processes, 15(2), 305-319. 
Appendix A. Mean monthly precipitation and temperature values retrieved from awhere.com.

\begin{tabular}{|c|c|c|c|c|c|c|c|c|c|c|c|c|c|}
\hline & \multicolumn{13}{|c|}{ Mean monthly precipitation (mm) } \\
\hline & Jan & Feb & Mar & Apr & \multicolumn{2}{|c|}{ May } & Jun & Jul & Aug & Sep & Oct & Nov & Dec \\
\hline 2009 & 23 & 2 & 0 & 56 & \multicolumn{2}{|c|}{147} & 199 & 122 & 213 & 135 & 164 & 56 & 27 \\
\hline 2010 & 22 & 18 & 1 & 88 & \multicolumn{2}{|c|}{210} & 314 & 111 & 288 & 343 & 10 & 5 & 3 \\
\hline 2011 & 0 & 10 & 5 & 64 & \multicolumn{2}{|c|}{47} & 135 & 133 & 137 & 164 & 204 & 8 & 12 \\
\hline 2012 & 2 & 3 & 4 & 27 & \multicolumn{2}{|c|}{145} & 55 & 86 & 241 & 77 & 51 & 3 & 1 \\
\hline 2013 & 16 & 6 & 2 & 25 & \multicolumn{2}{|c|}{59} & 114 & 97 & 114 & 84 & 76 & 27 & 17 \\
\hline 2014 & 16 & 5 & 21 & 89 & \multicolumn{2}{|c|}{95} & 171 & 54 & 170 & 140 & 147 & 20 & 3 \\
\hline 2015 & 10 & 6 & 36 & 39 & \multicolumn{2}{|c|}{135} & 168 & 105 & 102 & 212 & 214 & 100 & 5 \\
\hline Mean & 13 & 7 & 10 & 56 & \multicolumn{2}{|c|}{120} & 165 & 101 & 181 & 165 & 124 & 31 & 10 \\
\hline Std error & 3.4 & 2.0 & 5.1 & 10.1 & & .5 & 30.4 & 9.7 & 26.3 & 34.4 & 29.7 & 13.4 & 3.6 \\
\hline Std dev & 9.0 & 5.4 & 13.5 & 26.6 & & 5.9 & 80.5 & 25.8 & 69.5 & 91.0 & 78.7 & 35.4 & 9.7 \\
\hline$\%$ confidence & 8.3 & 5.0 & 12.5 & 24.6 & & 2.6 & 74.5 & 23.8 & 64.3 & 84.1 & 72.8 & 32.7 & 8.9 \\
\hline Adjusted prec. & 21.6 & 12.1 & 17.2 & 95.5 & & 5.7 & 284.0 & 174.3 & 311.0 & 283.8 & 212.7 & 53.9 & 16.8 \\
\hline & & & & & & lean n & monthly & tempera & ture $\left(0^{\circ}\right.$ & & & & \\
\hline Year & Jan & Feb & Mar & Al & & May & Jun & Jul & Aug & Sep & Oct & Nov & Dec \\
\hline 2009 & 18 & 19 & 19 & 2 & & 21 & 21 & 21 & 21 & 21 & 21 & 19 & 19 \\
\hline 2010 & 18 & 20 & 21 & 2 & & 22 & 21 & 21 & 21 & 20 & 19 & 19 & 17 \\
\hline 2011 & 19 & 20 & 19 & 2 & & 22 & 21 & 20 & 21 & 20 & 19 & 19 & 18 \\
\hline 2012 & 18 & 19 & 20 & 2 & & 21 & 20 & 20 & 20 & 20 & 19 & 18 & 18 \\
\hline 2013 & 19 & 19 & 19 & 2 & & 20 & 21 & 20 & 20 & 20 & 21 & 20 & 19 \\
\hline 2014 & 18 & 19 & 21 & 2 & & 21 & 21 & 21 & 20 & 21 & 20 & 18 & 18 \\
\hline 2015 & 20 & 19 & 19 & 2 & & 21 & 21 & 21 & 21 & 21 & 21 & 20 & 20 \\
\hline Mean & 19 & 19 & 20 & 2 & & 21 & 21 & 21 & 21 & 20 & 20 & 19 & 18 \\
\hline Std error & 0.26 & 0.22 & 0.29 & 0.2 & & 0.22 & 0.06 & 0.12 & 0.10 & 0.14 & 0.30 & 0.31 & 0.36 \\
\hline Std dev & 0.68 & 0.60 & 0.77 & 0.6 & & 0.59 & 0.17 & 0.33 & 0.28 & 0.37 & 0.80 & 0.83 & 0.95 \\
\hline \% confidence & 0.63 & 0.55 & 0.71 & 0.6 & & 0.55 & 0.15 & 0.30 & 0.25 & 0.35 & 0.74 & 0.77 & 0.88 \\
\hline
\end{tabular}


Appendix B. DEQ partial chemistry analysis for Calderas field measurements subset.

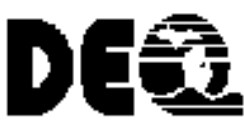

Report To: EDRICK RAMOS

1400 TOWNSEND DR

HOUGHTON MI 48931

\author{
MICHIGAN DEPARTMENT OF ENVIRONMENTAL QUAUTY \\ DRINKING WATER LABORATORY \\ USEPA Region V Drinking Water Cert. No. MI00003 \\ P.O. Box 30270 \\ Lansing. MI 48909 \\ TEL: (517) 335-8184 \\ FAX: (517) 335-8562
}

Sample Number

LF20144

Official Laboratory Report

\begin{tabular}{lllll} 
System Name/Owner: & & WSSNPool ID: & \\
Collection Address: & LAGUNA CALDERAS,AMATTLAN & Source: & \multicolumn{2}{l}{ Surface Water } \\
Collected By: & EDRICK RAMOS & Site Code: & GUATEMALA & \\
Township/WellifSection: & /I & Collector: & Other & \\
County: & Out of state & Date Collected: & $06 / 21 / 2012$ & $11: 00$ \\
Sample Point: & COMMUNITY INTAKE & Date Received: & $05 / 30 / 2014$ & $00: 12$ \\
Water System: & Untreated Public Distribution System & Purpose: & Other &
\end{tabular}

\begin{tabular}{|c|c|c|c|c|c|c|}
\hline \multicolumn{3}{|c|}{ TESTING INFORMATION } & \multicolumn{4}{|c|}{ REGULATORY INFORMATION } \\
\hline Analyte Name & $\begin{array}{l}\text { Result } \\
(\mathrm{mg} / \mathrm{L})\end{array}$ & $\begin{array}{c}\text { Date } \\
\text { Tested }\end{array}$ & $\begin{array}{c}\mathrm{RL} \\
(\mathrm{mg} / \mathrm{L})\end{array}$ & $\begin{array}{l}\text { MCLAL } \\
(\mathrm{mg} / \mathrm{L})\end{array}$ & Method & CAS \# \\
\hline Chloride & 20 & $05 / 30 / 2014$ & 4 & & SM 4500-ClE & $7647-14-5$ \\
\hline Fluoride & 0.60 & $06 / 04 / 2014$ & 0.1 & 4.0 & SM $4500 \mathrm{FC}$ & $16884-48-8$ \\
\hline Hardness as $\mathrm{CaCO} 3$ & 118 & $05 / 30 / 2014$ & 20 & & SM $2340 \mathrm{C}$ & HARD-DO-C \\
\hline Iron (automated) & Not detected & $05 / 30 / 2014$ & 0.1 & & SM $3500 \mathrm{FeB}$ & $7439-89-6$ \\
\hline Nitrate as $\mathrm{N}$ & Not Detected & $05 / 30 / 2014$ & 0.4 & 10 & $10-107-04-2-8$ & $14797-55-8$ \\
\hline Nitrite as N & Not detected & $05 / 30 / 2014$ & 0.05 & 1 & $10-107-04-2-B$ & $14797-65-0$ \\
\hline Ortho-Phospate as P & Not Detected & $05 / 30 / 2014$ & 0.1 & & EPA 365.1 & $7684-38-2$ \\
\hline Sodium (automated) & 18 & $05 / 30 / 2014$ & 5 & & SM $3500 \mathrm{NaB}$ & $7440-23-5$ \\
\hline Specific Conductance (umhos) & 375 & $06 / 05 / 2014$ & 1 & & EPA 120.1 & COND-DO-C \\
\hline Sulfate & Not detected & $05 / 30 / 2014$ & 10 & & SM 4500 SO4E & $14808-79-8$ \\
\hline Total Alkalinity as $\mathrm{CaCO} 3$ & 130 & $06 / 09 / 2014$ & 20 & & EPA 310.2 & TALK-DO-C \\
\hline
\end{tabular}

The ansyyses pertormed by the MDEQ Drinking Water Laborabry were conducted uaing methods approved by the U.3. Envronmental Protection Agency in accordance with the 3ate Drinking Water Act, 40 CFR parts 141-143, and other reguatory apencies as appropriste.

Your local health department has detailed information about the quality of drinking water in your area. If you have concerns about the health risks related to the test results of your sample, please contact the Environmental Health Section through the address and telephone number listed below.

\begin{tabular}{|c|c|c|}
\hline $\begin{array}{l}\text { CASa : Chemical Nbatract Bervice Reglatry Number } \\
\text { MCL: Marimum Contaminant Level } \\
\text { NL: Acton Level } \\
\text { FL: Reporting Umi }\end{array}$ & $\begin{array}{l}\text { mol : milligrams / Uter (ppm) } \\
\text { pom : parts per millon } \\
\text { MPN : Moet Probabie Number } \\
\text { CFU : Colony Forming Unit }\end{array}$ & $\begin{array}{l}\text { Laboratory Contacts } \\
\text { Drnking Water Unt Mor. Julls Pleper } \\
\text { aystems Mgmt. Unt Mor. George Kraztian }\end{array}$ \\
\hline
\end{tabular}

